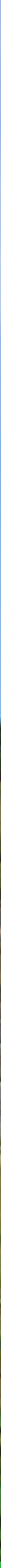

\title{
Effect van kleine landschapselementen en buitenlandse natuur op het duurzaam voorkomen van soorten in de provincie Limburg
}

Doorrekening met het MNP

Wieger Wamelink, Marjolijn van Adrichem, Henk Meeuwsen, Joep Frissel, Inez Woltjer, Bart de Knegt \& Rogier Pouwels 



\section{Effect van kleine landschapselementen en buitenlandse natuur op het duurzaam voorkomen van soorten in de provincie Limburg}

Doorrekening met het MNP

Wieger Wamelink, Marjolijn van Adrichem, Henk Meeuwsen, Joep Frissel, Inez Woltjer, Bart de Knegt \& Rogier Pouwels

Dit onderzoek is uitgevoerd door Wageningen Environmental Research in opdracht van en gefinancierd door de provincie Limburg.

Het rapport is gereviewd door dr. A. van Hinsberg van het Plan Bureau voor de Leefomgeving.

Wageningen Environmental Research

Wageningen, november 2018

Rapport 2912

ISSN 1566-7197 
Wamelink, G.W.W, M.H.C. van Adrichem, H.A.M. Meeuwsen, J.Y. Frissel, I. Woltjer, B. de Knegt \& R. Pouwels, 2018. Effect van kleine landschapselementen en buitenlandse natuur op het duurzaam voorkomen van soorten in de provincie Limburg; Doorrekening met het MNP. Wageningen, Wageningen Environmental Research, Rapport 2912. 60 blz.; 7 fig.; 5 tab.; 27 ref.

In de provincie Limburg komt veel natuur voor die niet standaard wordt meegenomen bij beoordelingen van de realisatie van natuurdoelen in het Natuurnetwerk Nederland met het MNP, zoals voor de evaluatie van het Natuurpact. Daarnaast heeft Limburg veel natuur die grenst aan buurlanden, het effect daarvan is ook niet meegenomen in veel studies. Met het MNP is daarom het effect van het toevoegen van de natuur buiten het NNN en het buitenland op het aantal potentiële populaties en het duurzaam voorkomen van soorten doorgerekend. Als er alleen naar Limburg wordt gekeken, dan neemt in beide scenario's het aantal duurzame soorten toe. Echter, op landelijke schaal is het effect nagenoeg afwezig, omdat vooral soorten toenemen die landelijk al duurzaam zijn. Het aantal populaties van die soorten neemt wel toe, ook landelijk.

In the Dutch province of Limburg not all natural areas are accounted for by the Model for Nature Policy (MNP) when assessing the realized nature targets in the Dutch Nature Network, for example in the studies for the evaluation of the 'nature pact' or Dutch governmental nature policy. Also the province has a long border with Germany and Belgium and the effect of their natural areas is not included in the evaluations. The MNP was therefore applied to calculate the effect of nature outside the official Nature Network and foreign nature on the viability of populations and species. When Limburg alone is assessed the viability of species and populations increases, especially if the extra natural areas are included. However, on a Dutch nation-wide scale the effects of both extra nature and foreign nature on species viability is negligible. This is due to the fact that the species that benefit in Limburg are already viable on a Dutch scale. The number of viable populations does increase, also in a national scale.

Trefwoorden: Limburg; biodiversiteit; ruimtelijke samenhang; kleine landschapselementen; planten; vogels; vlinders; model; MNP

Dit rapport is gratis te downloaden van https://doi.org/10.18174/463320 of op www.wur.nl/environmental-research (ga naar 'Wageningen Environmental Research' in de grijze balk onderaan). Wageningen Environmental Research verstrekt geen gedrukte exemplaren van rapporten.

2018 Wageningen Environmental Research (instituut binnen de rechtspersoon Stichting Wageningen Research), Postbus 47, 6700 AA Wageningen, T 0317480700 , www.wur.nl/environmental-research. Wageningen Environmental Research is onderdeel van Wageningen University \& Research.

- Overname, verveelvoudiging of openbaarmaking van deze uitgave is toegestaan mits met duidelijke bronvermelding.

- Overname, verveelvoudiging of openbaarmaking is niet toegestaan voor commerciële doeleinden en/of geldelijk gewin.

- Overname, verveelvoudiging of openbaarmaking is niet toegestaan voor die gedeelten van deze uitgave waarvan duidelijk is dat de auteursrechten liggen bij derden en/of zijn voorbehouden.

Wageningen Environmental Research aanvaardt geen aansprakelijkheid voor eventuele schade voortvloeiend uit het gebruik van de resultaten van dit onderzoek of de toepassing van de adviezen.

Wageningen Environmental Research Rapport 2912 | ISSN 1566-7197

Foto omslag: Wieger Wamelink 


\section{Inhoud}

$\begin{array}{ll}\text { Samenvatting } & \mathbf{5}\end{array}$

1

$\begin{array}{ll}\text { Inleiding } & \mathbf{7}\end{array}$

$\begin{array}{lll}1.1 & \text { Probleemstelling } & 7\end{array}$

$\begin{array}{lll}1.2 & \text { Projectdoelstelling } & 7\end{array}$

$\begin{array}{ll}\text { Materiaal \& Methode } & 8\end{array}$

$\begin{array}{lll}2.1 & \text { MNP } & 8\end{array}$

2.1.1 De kwaliteit van leefgebied $\quad 8$

2.1.2 Het duurzaam voorkomen soorten 9

2.1.3 Beleidsrelevante indicatoren 9

2.1.4 Toepassingsdomein MNP 9

2.2 De vier scenario's 9

$\begin{array}{lll}2.3 \text { Kaarten } & 10\end{array}$

2.3.1 Vegetatiekaart Limburg $\quad 10$

2.3.2 Vegetatiekaart buitenland 20

$\begin{array}{ll}2.3 .3 \mathrm{pH}-\text { en GVG-kaart Limburg } & 20\end{array}$

$\begin{array}{ll}2.3 .4 \mathrm{pH}-\text { en GVG-kaart buitenland } & 22\end{array}$

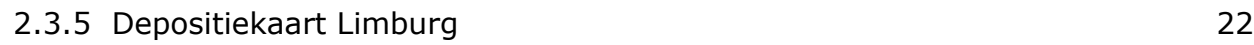

2.3.6 Depositiekaart buitenland $\quad 22$

$\begin{array}{lll}2.4 & \text { Koppeling soorten aan kaarten } & 22\end{array}$

$\begin{array}{lll}2.5 & \text { Modelruns en analyse } & 23\end{array}$

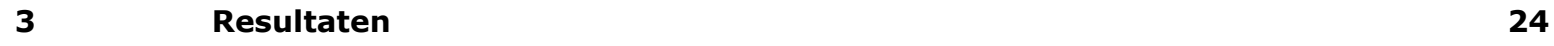

3.1 Duurzaam voorkomen van soorten in de provincie Limburg 24

$\begin{array}{ll}3.2 & \text { Landelijk duurzaam voorkomen } \\ \end{array}$

$\begin{array}{llr}4 & \text { Discussie } & 27\end{array}$

$\begin{array}{ll}\text { Literatuur } & 31\end{array}$

Bijlage $1 \quad$ Beheertypen gebruikt binnen het project 33

Bijlage 2 Extra vegetatietypen binnen Limburg 36

Bijlage 3 Vertaling van de Duitse vegetatietypenkaart in beheertypen 43

Bijlage 4 Vertaling van Vlaamse vegetatietypen in beheertypen 45

$\begin{array}{lll}\text { Bijlage } 5 & \text { Vertaling van de vegetatietypen in Wallonië } & 48\end{array}$

Bijlage 6 Vertaling van de CORINE-typen naar beheertypen 49

Bijlage 7 Verkrijgen Ndep waarden $5 * 5 \mathrm{~km}$ van EMEP-grid $\quad 50$

Bijlage $8 \quad$ Vegetatietypen en abiotiek buitenland $\quad 52$

Bijlage 9 Oppervlakte natuur binnen het NNN en toegevoegde natuur conform scenario 1 (toevoegen kleine landschapselementen) 53

Bijlage 10 Toegevoegde natuur per beheertype voor scenario 2, het buitenland $\quad 55$

Bijlage 11 Verslag bijeenkomst $\quad 56$

$\begin{array}{lll}\text { Bijlage } 12 \text { Review } & 58\end{array}$ 



\section{Samenvatting}

In de provincie Limburg bevindt zich veel natuur buiten het Natuurnetwerk (NNN, in Limburg Goudgroen geheten). Daarnaast heeft Limburg veel natuur die nabij natuur in het buitenland ligt. In veel studies naar ecologische effecten op duurzaam voorkomen van VHR-soorten zijn dergelijke effecten op de natuur binnen Limburg niet meegenomen. Zo zijn natuur buiten het NNN en de effecten van buitenlandse natuur op soorten die in Limburg voorkomen niet meegenomen bij de landelijke evaluatie van het Natuurpact, waarin de invloed van beleidsplannen op de stand van de terrestrische natuur in Nederland wordt geëvalueerd. Dit kan tot een onderschatting leiden van de staat van de natuur en de bijdrage die Limburg daaraan levert. Voor de evaluatie van het Natuurpact is het Model for Nature Policy (MNP) gebruikt. Om het effect van de natuur buiten het NNN en het effect van natuur in België en Duitsland op de natuur in Limburg te bepalen, is daarom hetzelfde model gebruikt. In totaal zijn er vier scenario's doorgerekend met het MNP:

0 . Het standaardscenario (scenario 0 ) voor de huidige situatie uit de evaluatie van het Natuurpact voor de vergelijking. Deze moest opnieuw worden gedraaid, omdat de vegetatiekaart verbeterd is en de soortenkoppeling met de vegetatietypen is bijgewerkt.

1. Scenario 1, waarbij extra natuur buiten het NNN is toegevoegd aan de kaart, voor zover dit bekend is uit andere databronnen. Het gaat daarbij o.a. om bermen, holle wegen, uiterwaarden, maar ook alle landschapstypen van de SNL.

2. Scenario 2, waarbij een ring van $15 \mathrm{~km}$ rondom Limburg is gelegd en alle buitenlandse, nietstedelijke gebieden een vegetatietype (SNL-beheertype) aanduiding hebben gekregen.

3. Scenario 3, waarbij scenario 1 en 2 zijn gecombineerd.

Als modelinvoer is gebruikgemaakt van de beheertypenkaart. Voor de scenario's zijn aan deze kaart extra gebieden toegevoegd, die steeds zijn vertaald naar een beheertype, inclusief agrarische en landschapstypen. Daarnaast maakt het MNP gebruik van invoerkaarten voor de zuurgraad van de bodem $(\mathrm{pH})$, de gemiddelde voorjaarsgrondwaterstand (GVG) en de stikstofdepositie. De pH en de GVG zijn voor de toegevoegde gebieden bijgeschat. De bestaande stikstofdepositiekaart is al landsdekkend (OPS-model; Sauter et al., 2018), voor de depositie in het buitenland is gebruik gemaakt van kaarten uit het Europese EMEP-model (webdab.emep.int/Unified_Model_Results/).

De modelberekeningen van de scenario's laten zien dat vooral het toevoegen van de kleine landschapselementen grote invloed heeft op de uitkomsten binnen Limburg. Het aantal populaties van soorten en het aantal soorten waarvoor in Limburg duurzame condities zijn, nemen beide toe door aanwezigheid van kleine landschapselementen. Ook het meenemen van het buitenland geeft binnen Limburg een hoger aantal populaties en meer duurzaam beschermde soorten, al is het effect wel kleiner. Het gecombineerde scenario geeft een nog hogere toename van populaties en duurzaam voorkomende soorten binnen Limburg. Als het resultaat landelijk wordt bekeken, neemt het aantal populaties als gevolg van de scenario's voor Limburg ook toe, maar het aantal duurzaam voorkomende soorten niet. Dit geeft aan dat in Limburg, als gevolg van het aanwezigheid van de kleine landschapselementen en natuur in het buitenland, condities van soorten verbeterd worden die in geheel Nederland al duurzaam voorkomen. Op zich is dit winst, maar als de provincie Limburg een hogere bijdrage wil leveren aan de landelijke duurzame instandhouding van soorten, dan is het wenselijk dat het Limburgse natuur- en landschapsbeleid gunstige condities schept voor met name andere soorten dan die nu al door de landelijke inspanningen in een gunstige staat van instandhouding zijn gebracht. Dit zou bijvoorbeeld kunnen door nieuwe natuur met andere vegetatiedoeltypen te ontwikkelen of de kwaliteit van bestaande gebieden te verhogen. Ook zouden maatregelen gericht op vergroting van de ruimtelijke samenhang kunnen bijdragen aan een hoger doelbereik. Indien geen aanvullende gedetailleerde meet- en/of expertinformatie op lokaal niveau over knelpunten beschikbaar komt, zou de provincie - op basis van de huidige inzichten, modeluitkomsten en eerdere studies - qua (kosten) effectiviteit hoogstwaarschijnlijk prioriteit kunnen geven aan investeren in de kwaliteit van (grotere) natuurgebieden. Tweede prioriteit zou ons inziens gegeven worden aan ontwikkeling van nieuwe natuur die de bestaande natuur versterkt. De prioritering van maatregelen zal echter per gebied sterk variëren. Daarbij hebben in de provincie Limburg sommige 
belangrijke natuurgebieden (zoals het Savelsbos of het Geuldal) qua vorm een grote randlengte, waardoor zij wel groot zijn, maar sterk beïnvloed worden door omringende agrarisch dan wel stedelijk/industrieel landgebruik. Een verbetering qua kwaliteit kan op die locaties waarschijnlijk alleen gerealiseerd worden als verbeteringen doorgevoerd worden in het omringende landschap. 


\section{$1 \quad$ Inleiding}

\section{$1.1 \quad$ Probleemstelling}

In de provincie Limburg is de vraag gerezen hoeveel natuur buiten het Natuurnetwerk, Goudgroen in Limburg, bijdraagt aan het duurzaam in stand houden van dier- en plantpopulaties. Buiten het aangewezen gebied voor de NNN, en zoals vastgelegd voor de SNL in de beheertypen, bevindt zich ook natuur die natuurwaarden vertegenwoordigen. Als die gebieden groot genoeg zijn of verbonden zijn met het netwerk binnen Goudgroen kunnen ze van invloed zijn op het duurzaam voorkomen van populaties en op de biodiversiteit. Daarnaast zijn ook aangrenzende natuurgebieden buiten Limburg van belang voor de stand van de biodiversiteit in Limburg. Het gaat daarbij niet alleen om natuur in de aangrenzende provincies in Nederland (Noord-Brabant en Gelderland), maar vooral ook om natuur in België en Duitsland. De informatie in de buurlanden over de ligging van natuur en de kwaliteit daarvan, bepalend voor het duurzaam voorkomen van de populaties, wordt niet standaard betrokken in beleidsevaluaties gedaan met het MNP. De informatie is wel te achterhalen maar veelal beschikbaar p een ander detailniveau dan voor Nederland. Het is echter wel goed mogelijk om de wel beschikbare informatie te betrekken bij de doorrekening voor Limburg. Informatie over die gebieden is beschikbaar via het Natura 2000-netwerk en via satellietbeelden van Corine (www.eea.europa.eu/publications/COR0-landcover, laatst bezocht op 30-7-2018).

\section{$1.2 \quad$ Projectdoelstelling}

Doel van het project is om inzicht te geven wat de bijdrage van de natuur buiten de POL (NNN) gebieden in de provincie Limburg is op de duurzame instandhouding van dier- en plantpopulaties binnen de NNN. De bijdrage is doorgerekend voor drie scenario's: een scenario inclusief de natuur buiten de NNN, een scenario waarbij de NNN inclusief buitenland is doorgerekend en een scenario waarbij de natuur buiten de NNN wordt gecombineerd met de natuur buiten de NNN, inclusief het buitenland. Deze scenario's zijn doorgerekend voor soorten van de vogel- en habitatrichtlijn en de Rode Lijst-soorten voor zover beschikbaar in het MNP-model. 


\section{Materiaal \& Methode}

\section{$2.1 \quad$ MNP}

Het MNP (Pouwels et al., 2016b) beoordeelt of milieu- en ruimtecondities in het landschap op voldoende locaties geschikt zijn voor een soort om zich in het landschap te kunnen handhaven. Voordeel van het model is dat effecten worden gekwantificeerd en gevolgen van geheel verschillende type aspecten en maatregelen die daarop ingrijpen bij elkaar worden opgeteld (integrale analyses). Nadeel is dat dit alleen kan door de werkelijkheid modelmatig sterk vereenvoudigd te beschrijven.

\subsubsection{De kwaliteit van leefgebied}

De mate waarin het leefgebied geschikt is, wordt in het MNP bepaald door eenvoudige responsiecurves (paragraaf 2.6 en Bijlage 3 in Pouwels et al., 2016a) te gebruiken. Voor de bepaling van de parameterwaarden is in het model zo veel mogelijk gebruikgemaakt van empirisch onderzoek met betrekking tot bijvoorbeeld optimale grondwaterstanden en kritische waarden voor atmosferische depositie. Voor sommige soorten wordt bij de bepaling van deze waarden gebruikgemaakt van relaties uit meer geavanceerde procesmodellen, zoals LARCH en de Natuurplanner, en voor enkele soorten worden ze bij geschat op basis van aanverwante soorten.

Sommige factoren die meer lokaal bepalend zijn voor de aanwezigheid van soorten, zoals jacht (of andere beïnvloeding/verstoring), barrières (wegen, hekken etc.), worden in het model niet meegenomen. Ook wordt de impact van invasieve soorten buiten beschouwing gelaten. Deze impact is echter met name belangrijk voor soorten in aquatische milieus (Verbrugge et al., 2015), waarvoor het model nu niet ontwikkeld is.

Het model gaat ervan uit dat de fysieke maatregelen qua beheer optimaal worden uitgevoerd. Er wordt als het ware aangenomen dat bijvoorbeeld plaggen of maaien gebeurt in het - voor alle soorten - goede seizoen, met de juiste frequentie en ruimtelijke schaal. In de praktijk blijkt het echter lastig om fysieke ingrepen ecologisch volledig goed uit te voeren (Van Turnhout et al., 2008). Als bijvoorbeeld het natuurbeheer op te grote schaal of te frequent wordt uitgevoerd, kan er zelfs schade aan de natuur ontstaan doordat soorten verdwijnen.

Voor het bepalen van de geschiktheid van het leefgebied (stap 1) wordt gebruikgemaakt van een eenvoudige HSI-modelstructuur (Habitat Suitability Index). De index ligt tussen 0 en 1 en geeft de ratio aan van de kwaliteit van het onderzochte gebied ten opzichte van een 'perfect' gebied. Ook al hebben HSI-modellen hun beperkingen (Bender et al., 1996) en kunnen ze een grote onzekerheid hebben, ze zijn algemeen geaccepteerd om op een eenvoudige en inzichtelijke wijze de geschiktheid van het leefgebied in beeld te brengen (Terell et al., 1982; Duel et al., 1996; Sierdsema et al., 2015). In het MNP werken de verschillende drukfactoren, zuurgraad van de bodem, gemiddelde voorjaarsgrondwaterstand, stikstofdepositie en temperatuur versterkend op elkaar en worden de indexen met elkaar vermenigvuldigd. Deze opzet is ook gebruikt voor meer recentere HSI-modellen voor bijvoorbeeld vogels op de Veluwe (Sierdsema et al., 2008). Echter in een andere studies - tevens voor andere soorten in Gelderland - worden drukfactoren gesommeerd (Sierdsema et al., 2015). Door de US Fish and Wildlife Service (1981) wordt vaak het geometrische gemiddelde genomen. Elke functie heeft zijn specifieke voor- en nadelen. Verschillen in uitkomsten op basis van de methoden kunnen groot zijn, nader onderzoek hiernaar is nodig, maar geen onderdeel van dit onderzoek. 


\subsubsection{Het duurzaam voorkomen soorten}

Het MNP brengt geen daadwerkelijk (duurzaam) voorkomen van soorten in kaart. Het model analyseert of de condities geschikt zijn voor het duurzaam voortbestaan van soorten. Het model bekijkt per locatie de benodigde condities van de daar voorkomende soorten en vergelijkt dit met de berekende condities. De condities van een leefgebied van een soort worden bepaald door de het type leefgebied (beheertype), de omvang van het leefgebied (ruimtelijke samenhang) en de kwaliteit (geschiktheid) ervan. Het geeft op deze wijze de potentie voor een gebied als leefgebied voor een soort weer zonder te beoordelen of de soort er daadwerkelijk voorkomt. Wel zijn voor de huidige situatie geschiktheid en aanwezigheid met elkaar vergeleken, waarbij het model nu alleen is toegepast voor die soorten waarbij verspreidingspatroon en geschikt leefgebied overeenkomen.

\subsubsection{Beleidsrelevante indicatoren}

Het model beperkt zich tot landnatuur voor de soortgroepen vaatplanten, dagvlinders en broedvogels. Deze soorten zijn vaak de grootste soortgroepen in het Nederlandse natuurbeleid, zijn representatief voor de schaalniveaus landschap, vegetatiestructuur en standplaats (Carignan \& Villard, 2002) en bieden zodoende een betere afspiegeling van biodiversiteit dan wanneer één schaalniveau zou worden meegenomen (Wolters et al., 2006; Eglington et al., 2012). Daarnaast leggen provincies bij bepaling van natuurkwaliteit ook de nadruk op planten, vlinders en broedvogels (Van Beek et al., 2014).

\subsubsection{Toepassingsdomein MNP}

Het model gebruikt invoerbestanden met een resolutie van $25 \times 25$ meter. Daarbij is het mogelijk dat er verschillende vegetatie/beheertypes binnen één cel aanwezig zijn. Met name voor het modelleren van vaatplanten is deze resolutie nodig; het voorkomen van deze soortgroep wordt bepaald door de condities op standplaatsniveau. Een fijner schaalniveau is niet mogelijk, omdat de ruimtelijke informatie voor vegetaties niet op dit niveau beschikbaar is. Wanneer het schaalniveau grover zou worden, zou dit met name voor de voorspelling van vaatplanten ongunstig zijn.

Dit fijne schaalniveau zou kunnen suggereren dat ook uitspraken gedaan worden op een zeer fijn schaalniveau. Het MNP is echter ontwikkeld voor het analyseren van soortgroepen op landelijk en provinciaal niveau. Het model is niet geschikt voor analyses op een lager schaalniveau, zoals op gebiedsniveau of voor analyses van individuele soorten. De resolutie van het instrument en de kwaliteit van de invoerdata zijn hiervoor niet hoog genoeg. Denk bijvoorbeeld aan onzekerheden over het grondwaterpeil. Daarnaast wordt voor de beoordeling gebruikgemaakt van drempelwaarden met betrekking tot duurzaam voorkomen die gericht zijn op het landelijke schaalniveau. Voor analyses op provinciaal niveau worden dan uitsplitsingen gemaakt van nationale analyses.

Het model analyseert het landschap als een 'steady state' of evenwichtssituatie. Bij analyses van toekomstige situaties wordt verondersteld dat de doorgerekende interventies hun volledige effect hebben bereikt. Het model houdt daarbij geen rekening met geleidelijke effecten die optreden.

\subsection{De vier scenario's}

Voor de provincie Limburg zijn vier verschillende scenario's doorgerekend:

1. Het standaardscenario (scenario 0). Dit is het landelijk scenario dat o.a. voor de berekeningen van de balans van de leefomgeving (PBL, 2016) wordt gebruikt. Dit scenario is opnieuw gedraaid, omdat er met de neergeschaalde beheertypenkaart (Pouwels et al., 2017) is gedraaid en met een aangevulde soortenlijst. Dit scenario wordt gebruikt als vergelijkingsscenario voor de beide andere scenario's.

2. Het kleine landschapselementenscenario (scenario 1). Binnen Limburg zijn alle beschikbare natuurlijke vegetaties, zoals wegbermen, taluds, boerengeriefbosjes, bomrijen, individuele bomen, uiterwaarden van Rijkswaterstaat etc. toegevoegd aan de al bestaande neergeschaalde beheertypenkaart (Pouwel et al., 2016). De toegevoegde typen zijn vertaald naar beheertypen. Daarbij is ook voor het eerst binnen het MNP gebruikgemaakt van de Landschapstypen van de SNL 
(www.bij12.nl/onderwerpen/natuur-en-landschap/index-natuur-en-landschap/de-index-natuur-enlandschap/). Aan de landschapstypen waren nog geen soorten gekoppeld en dat is voor dit scenario ook voor het eerst uitgevoerd.

3. Het buitenlandscenario (scenario 2). Limburg heeft een lange buitenlandse grenslijn met ook veel grensoverschrijdende gebieden. Anders dan tussen provinciegrenzen worden landsgrensoverschrijdende gebieden niet standaard meegenomen in MNP-berekeningen, omdat veelal gekeken wordt naar landelijke doelstellingen. Echter het niet meenemen zou tot een onderschatting kunnen leiden van het aantal soorten dat duurzaam kan voorkomen in Limburg (en Nederland). In een buffer van $15 \mathrm{~km}$ rond Limburg zijn alle aanwezige natuurgebieden en beheertypen geïdentificeerd, zodat de invloed hiervan doorgerekend konden worden. In de resultaten is dit scenario in tweeën gesplitst: resultaten exclusief buitenlandse populaties en inclusief buitenlandse populaties. Voor het aantal duurzame populaties binnen Nederland is in principe alleen het eerste subscenario interessant, immers buitenlandse populaties tellen niet mee voor Nederland. Door de gebiedsgrootte kan het echter zo zijn dat er (meer) duurzame populaties of sleutelpopulaties voor kunnen voorkomen in Nederland. Die tellen dan mee in dit scenario. Ter vergelijking is ook het scenario met het buitenlandse oppervlak verder uitgewerkt om inzicht te geven in wat het effect zou zijn van zoveel gebiedsuitbreiding van de aanwezige kwaliteit. Voor het buitenland waren (nog) geen abiotische gegevens beschikbaar. De stikstofdepositie, gemiddelde voorjaarsgrondwaterstand en de $\mathrm{pH}$ zijn voor dit project voor het buitenland globaal ingeschat.

4. Het combiscenario (scenario 3). In dit scenario zijn scenario 1 en 2 gecombineerd. Dit geeft inzicht in wat kleine landschapselementen en het buitenland samen bijdragen aan het duurzaam voorkomen van de VHR (typische) soorten en de Rode Lijst-soorten. Voor het buitenlandscenario geldt ook hier dat alleen de bijdrage binnen Limburg wordt meegenomen.

Hierna worden de benodigde aanpassingen en uitbreidingen voor het draaien van de drie scenario's in detail besproken.

\subsection{Kaarten}

In deze paragraaf worden de aanpassingen aan de beheertypenkaart (voor de typen zie Bijlage 1 ) en de productie van de beheertypenkaart voor het buitenlandscenario beschreven. Daarnaast wordt beschreven hoe de abiotiekkaarten voor de extra natuur in Limburg en het buitenlandscenario zijn gemaakt.

\subsubsection{Vegetatiekaart Limburg}

Als basis voor de kaart met de vegetatietypen dient de beheertypenkaart, opgesteld door de provincie Limburg voor het Natuurbeheerplan Limburg 2018 die op 19 sept. 2017 is vastgesteld. Omdat de provincie Limburg een recentere beheertypekaart heeft aangeleverd dan beschikbaar was uit de laatste evaluatie van het Natuurpact, is als eerste stap een zogenaamde neerschaling van de beheertypenkaart (Pouwels et al., 2017) opnieuw uitgevoerd. Neerschaling vindt plaats voor vegetatietype N05.01 Moeras (N08.01 Open Duin komt niet in Limburg voor). Omdat er een nieuwe beheertypenkaart is gebruikt, moest ook het 0 -scenario opnieuw gedraaid worden met het MNP.

Na de neerschaling is informatie van de volgende kaarten toegevoegd:

De nieuwe beheertypenkaart van Limburg is aangevuld met gegevens uit verschillende andere bestanden. De wijze waarop is afhankelijk van het soort type. Bij de L-typen (landschapselementen) is de beheertypenkaart leidend en deze typen zijn als eerste aangevuld met gegevens uit andere bestanden met lijnvormige elementen. De resulterende L-typenkaart is vervolgens leidend boven de $\mathrm{N}$ - (natuurtypen) en A-typen (agrarische typen) uit de beheertypenkaart; alleen plekken zonder L-type zijn opgevuld met een $\mathrm{N}$ - of A-type. Bij het aanvullen van de $\mathrm{N}$ - en A-typen zijn de $\mathrm{N}$-typen leidend en kunnen niet worden overschreven door gegevens uit een ander bestand. A-typen kunnen wel worden overschreven, evenals de typen die zijn aangeduid als 'nog om te vormen'. Samengevat komt de werkwijze neer op de hieronder genoemde stappen, waarbij een strikte hiërarchie is 
gehanteerd: het lager gerangschikte bestand wordt alleen gebruikt om lege plekken (of A-typen en 'nog om te vormen') op te vullen die er in die fase nog zijn.

1. Beheertypenkaart L-typen

2. Vegetatiekartering Limburg, lijnvormig

3. Bomenrijen en heggen uit Top10NL

4. Boombasis, vrijstaande en groepjes bomen die niet corresponderen met Top10NL

5. Beheertypen (exclusief 'om te vormen' en agrarische typen)

6. Vegetatiekartering Limburg, vlakvormig

7. Bos uit Top10NL

8. Natuurrealisatie op land van Rijkswaterstaat en waterschappen

9. Agrarische beheertypen

Het bestand met kleine landschapselementen dat door de provincie Limburg is aangeleverd, is niet gebruikt. Een beperkte controle leverde al diverse elementen op, boomgaarden bijvoorbeeld, die op de luchtfoto van 2016 niet meer aangetroffen werden.

In totaal is er 25384 hectare toegevoegd of binnen het NNN van functie veranderd op totaal 54191 hectare van de beheertypenkaart van het NNN in Limburg (Figuren 1-3 en Bijlage 9).

Uit de hierboven beschreven werkwijze blijkt dat bij het aanvullen van de beheertypenkaart gebruik is gemaakt van diverse andere bestanden. Een uitgebreide beschrijving is te vinden in Bijlage 2 , inclusief de vertaling van de typen op de kaarten naar beheertypen. 


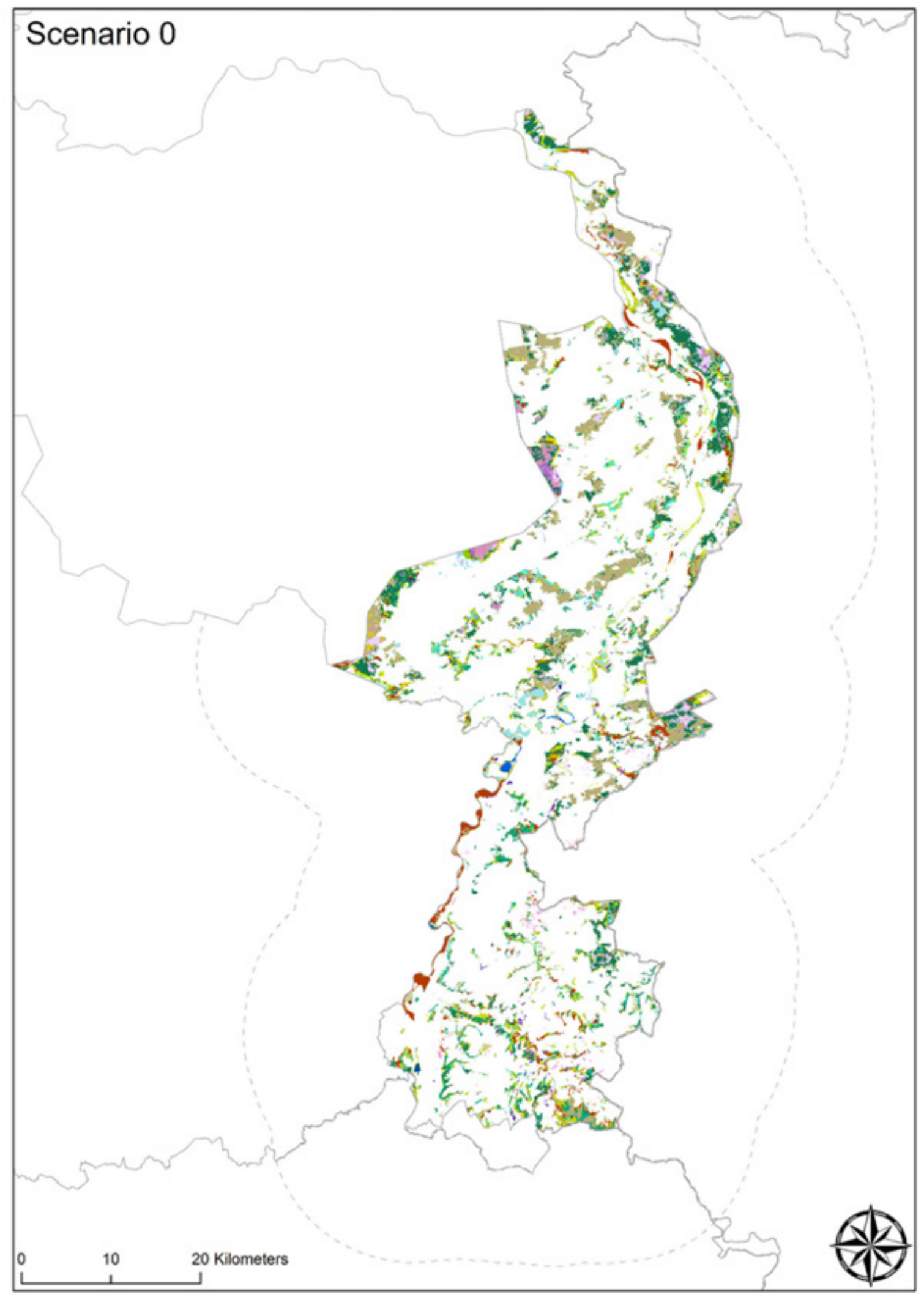

Figuur 1 Beheertypenkaart van Limburg, zoals die wordt gebruikt bij de standaard doorrekening voor Nederland. De hoofdtypen N05.01 Moeras zijn daarin neergeschaald tot subtypen; deze zijn op bovenstaande kaart niet weergegeven. Deze nieuwe kaart is voor scenario 0 gebruikt en is aangevuld voor alle andere scenario's. Voor de legenda zie p. 17. 


\section{Legend}

\begin{tabular}{|c|c|}
\hline O Geen & N06.04 Vochtige heide \\
\hline A01.01 Weidevogelgebied & N06.05 Zwakgebufferd ven \\
\hline A01.02 Akkerfaunagebied & N06.06 Zuur ven en hoogveenven \\
\hline A01.03 Ganzenfourageergebied & N07.01 Droge heide \\
\hline A02.01 Botanisch waardevol grasland & N07.02 Zandverstuiving \\
\hline A02.02 Botanisch waardevol akkerland & N10.01 Nat schraalland \\
\hline A13.02 Struweel en ruigte & N10.02 Vochtig hooiland \\
\hline L01.01 Poel en kleine historische wateren & N11.01 Droog schraalgrasland \\
\hline L01.02 Houtwal en houtsingel & N12.01 Bloemdijk \\
\hline L01.03 Elzensingel & N12.02 Kruiden- en faunarijk grasland \\
\hline L01.05 Knip- of scheerheg & N12.03 Glanshaverhooiland \\
\hline L01.06 Struweelhaag & N12.04 Zil- en overstromingsgrasland \\
\hline L01.07 Laan & N12.05 Kruiden- of faunarijke akker \\
\hline L01.08 Knotboom & N12.06 Ruigteveld \\
\hline L01,09 Hoogstamboomgaard & N13.01 Vochtig weidevogelgrasland \\
\hline L01.10 Struweelrand & N13.02 Wintergastenweide \\
\hline L01.11 Hakhoutbosje & N14.01 Rivier- en beekbegeleidend bos \\
\hline L01.12 Griendje & N14.02 Hoog-en laagveenbos \\
\hline L01.13 Bomenrij of solitaire boom & N14.03 Haagbeuken- en essenbos \\
\hline L01.14 Rietzoom en klein rietperceel & N15.01 Duinbos \\
\hline L01.15 Natuurvriendelijk oever & N15.02 Dennen-, eiken- en beukenbos \\
\hline L01.16 Bossingel & N16.01 Droog bos met productie \\
\hline N00.01 Nog om te vormen landbouwgrond naar natuur (inrichting) & N16.02 Vochtig bos met productie \\
\hline N01.03 Rivier- en moeraslandschap & N16.03 Droog bos met productie \\
\hline N02.01 Rivier & N16.04 Vochtig bos met productie \\
\hline N03.01 Beek en Bron & N17.02 Droog hakhout \\
\hline N04.01 Kranswierwater & N17.03 Park- of stinzenbos \\
\hline N04.02 Zoete Plas & N17.06 Vochtig en hellinghakhout \\
\hline N05.01 Moeras & S01.13 Bomenrij of solitaire boom in woonkern \\
\hline N05.01.02 Landriet & T15.02 Dennen-, eiken- en beukenbos in kem \\
\hline N05.01.05 Veenmosrietland & W00.01 Weg en pad \\
\hline N05.01.06 Moerasstruweel & W00.02 Overig \\
\hline N05.01.07 Moerasloofbos & W00.03 Bebouwing \\
\hline N05.01.08 Moerasnaaldbos & W00.04 Bomenrij of heg \\
\hline N05.01.10 Hoogveenbos & W00.05 Steenglooiing of krib \\
\hline N05.01.11 Galigaanmoerassen & W00.06 Agrarisch \\
\hline N05.02 Gemaaid rietland & W01.01 Rivierduin, open zand in riviergebied \\
\hline N06.01 Veenmosrietland en moerasheide & W02.01 Sloten \\
\hline N06.03 Hoogveen & W03.01 Breed water \\
\hline
\end{tabular}

Legenda behorend bij alle beheertypekaarten die gebruikt zijn voor de doorrekening van de scenario's (Figuren 1-4). Naast de natuurtypen ( $N$ ) worden ook de agrarische typen ( $A$ ), de landschapselementen $(L)$ en de extra typen $(W)$ en de stad typen (S en $T$ ) gegeven. De neergeschaalde subtypen zijn niet apart genoemd. 


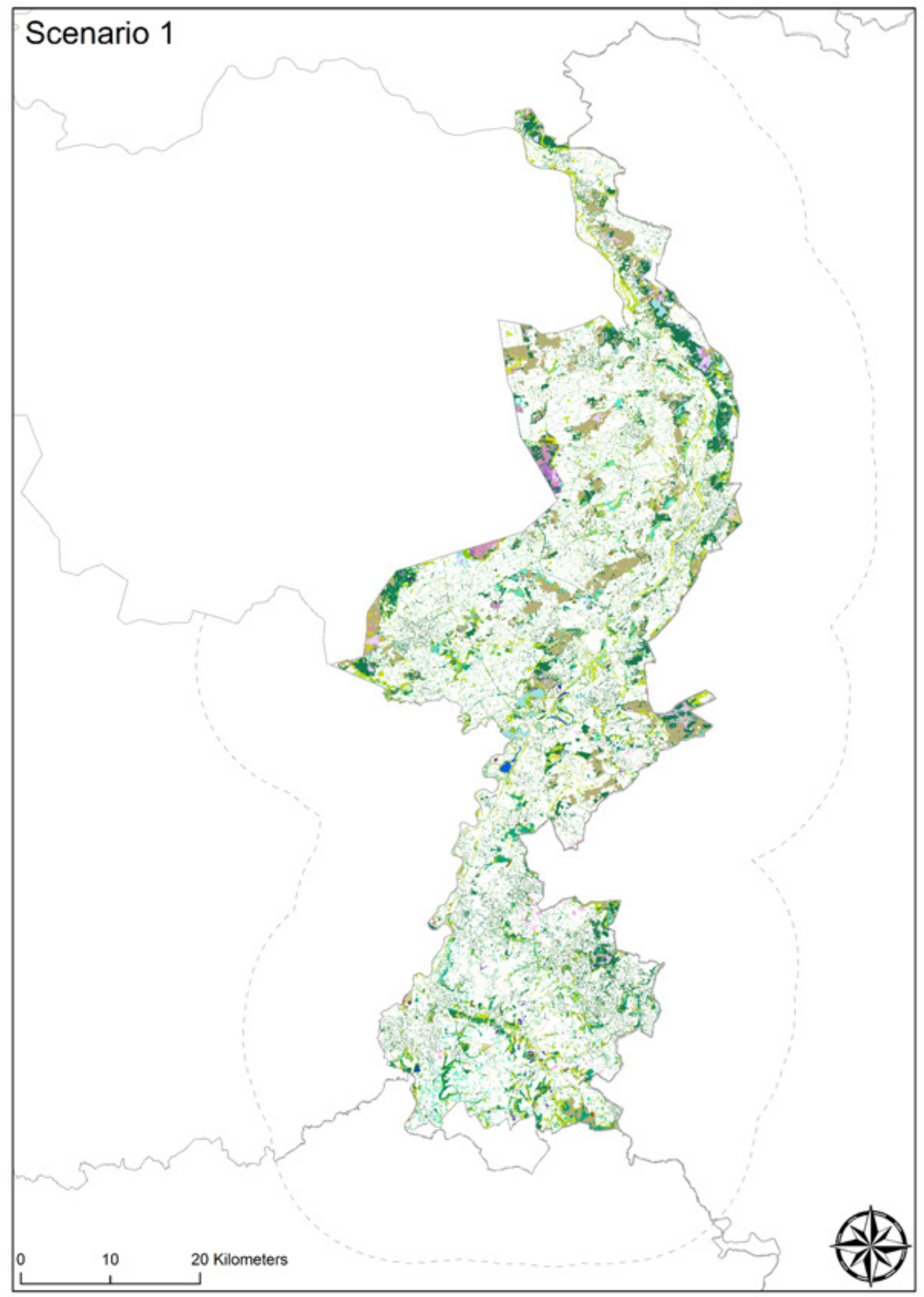

Figuur 2 Invoerkaart met beheertypen met daaraan toegevoegd de kleine landschapselementen voor Limburg. Deze kaart is gebruikt voor scenario 1 en het gecombineerde scenario 3. Voor de legenda zie p. 17. 


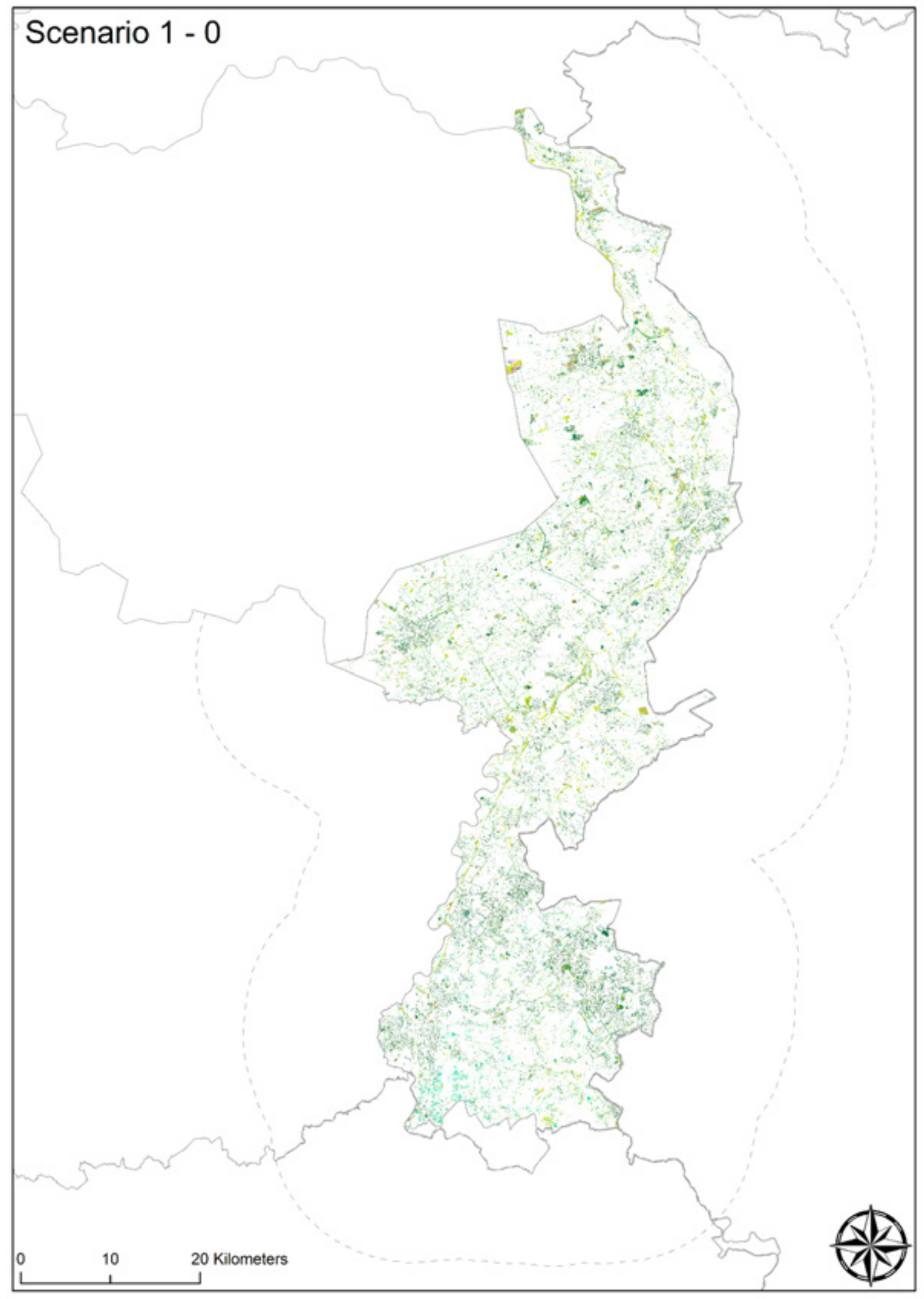

Figuur $3 \quad K l e i n e ~ l a n d s c h a p s e l e m e n t e n k a a r t$ voor Limburg. De kaart geeft het verschil tussen de basis beheertypenkaart (scenario 0) en de beheertypenkaart inclusief kleine landschapselementen (scenario 1). Deze kaart bevat ook de landschapstypen (L-typen) die niet eerder gebruikt zijn voor een doorrekening. De legenda is te vinden op $p .17$. 


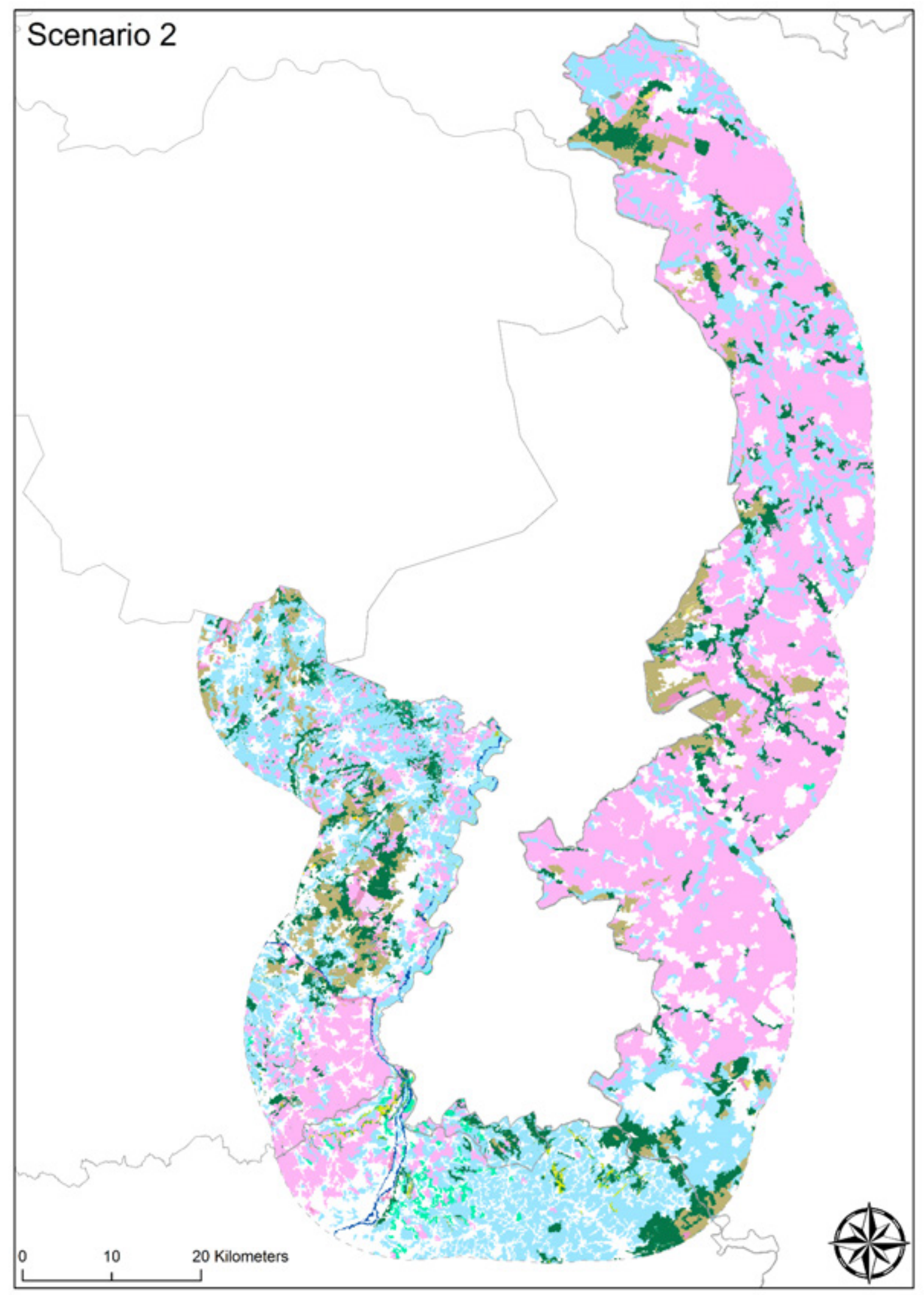

Figuur 4 Invoerkaart van beheertypen in buitenland in een straal van $15 \mathrm{~km}$ rondom Limburg. Deze kaart is gebruikt voor scenario 2 en het combiscenario 3. Daarbij zijn de grote vlakken agrarisch gebied benoemd tot agrarische typen van lage kwaliteit. Voor de legenda zie p. 17. 


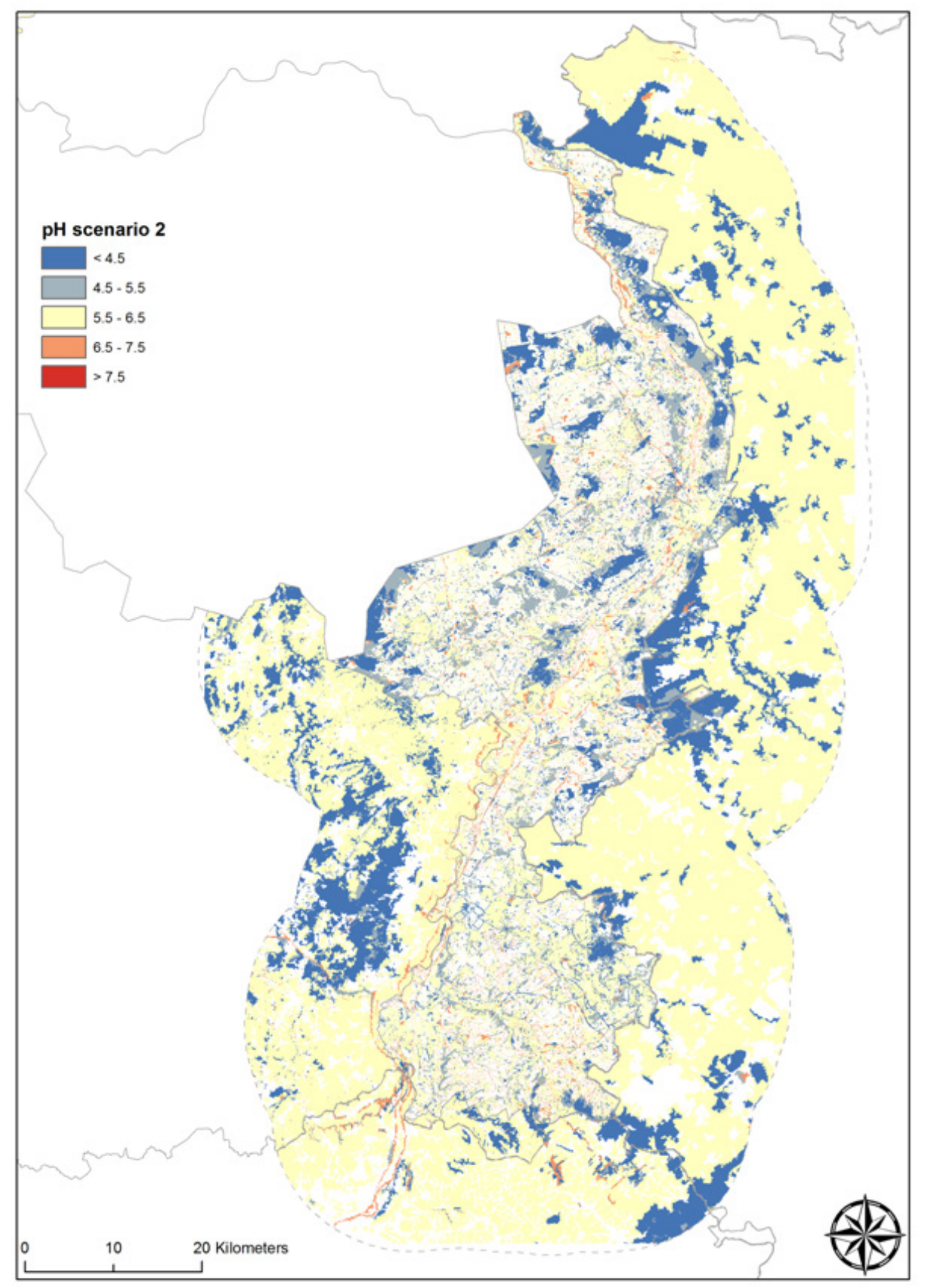

Figuur $5 \quad$ Kaart met de $\mathrm{pH}$-waarden voor Limburg en de 15km-zone rondom Limburg. De $\mathrm{pH}$ waarden binnen en buiten Limburg zijn op een verschillende wijze tot stand gekomen. 


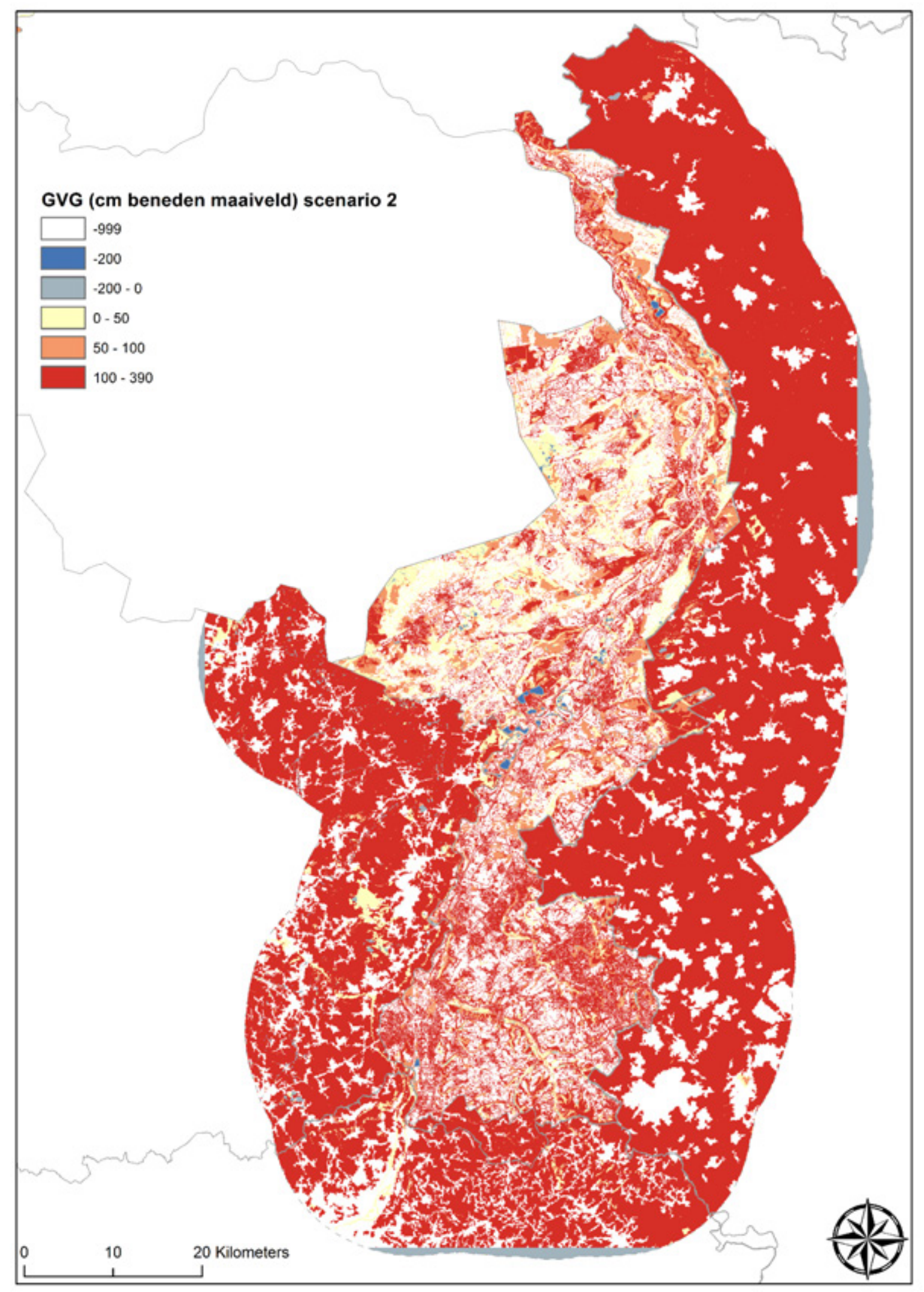

Figuur 6 Gemiddelde voorjaarsgrondwaterstand (GVG) voor Limburg en de 15km-randzone. De GVG binnen en buiten Limburg zijn op verschillende wijze tot stand gekomen. Door de grote verschillen tussen droogste en natste gebieden lijkt er weinig variatie aanwezig in de GVG. Dit is voor Limburg zelf niet het geval, de nuances vallen echter grotendeels weg. 


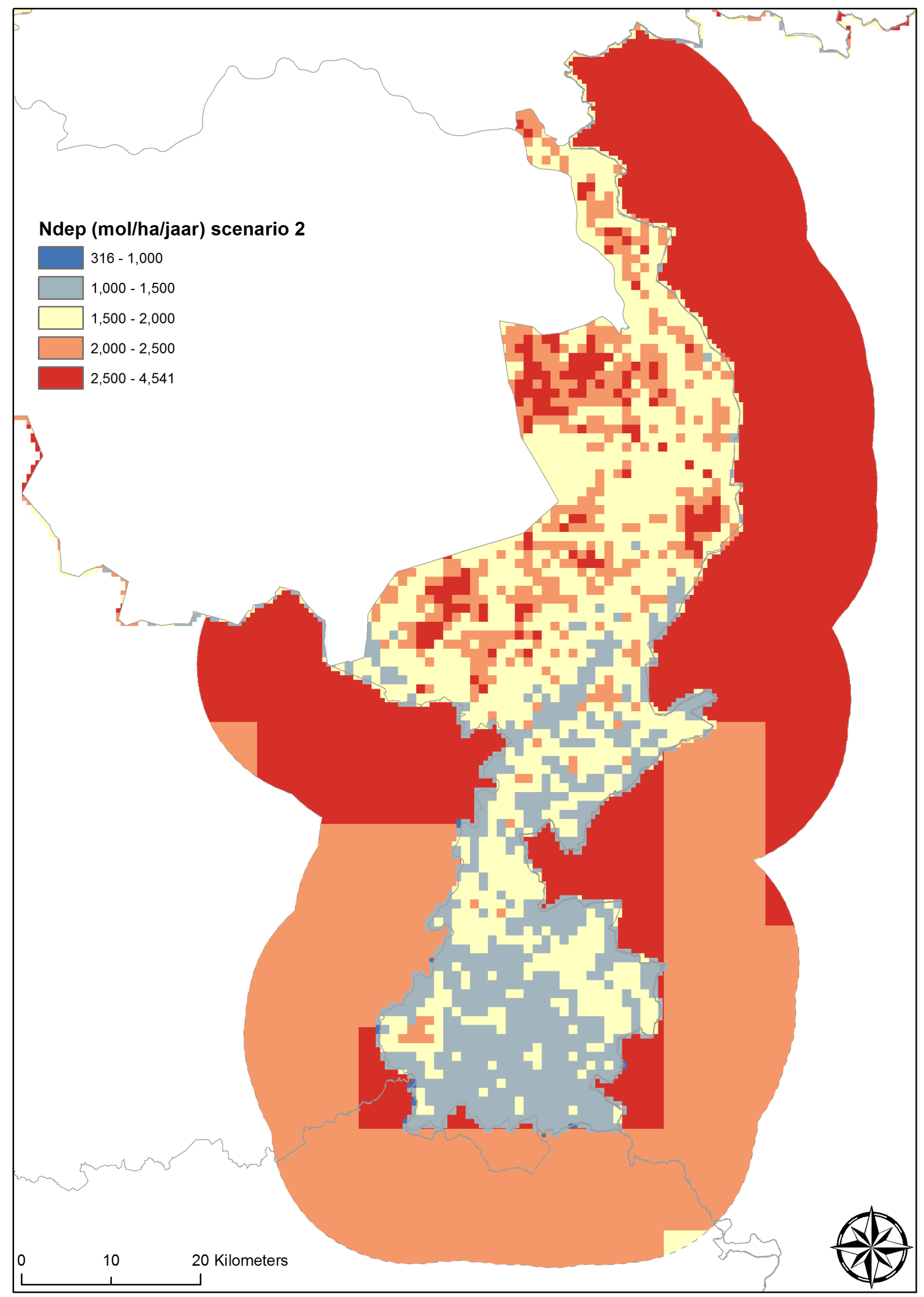

Figuur $7 \quad$ Stikstofdepositie voor Limburg en de $15 \mathrm{~km}$-zone rondom Limburg. De data binnen Limburg zijn gebaseerd op OPS (Sauter et al. 2018), die voor de zone op EMEP-data (webdab.emep.int/Unified_Model_Results/), wat leidt tot grote schaalverschillen en grote overgangen. Verwacht mag worden dat ook in Duitsland en België er in praktijk veel meer variatie aanwezig zal zijn. Bovendien lijkt op basis van vergelijking van EMEP en OPS dat de depositie in het buitenland hoger wordt ingeschat. 


\subsubsection{Vegetatiekaart buitenland}

Om de vegetatiekaart voor scenario 2 te maken, is gebruikgemaakt van gegevens uit drie verschillende gebieden, Duitsland, Wallonië en Vlaanderen (Figuur 4).

Voor Duitsland is gebruikgemaakt van landelijke en regionale vegetatiekaarten. De typen zijn vertaald in typen aanwezig op de beheertypenkaart (voor de vertaling van de typen zie Bijlage 3). Er is voor gekozen om alle agrarische gebieden als agrarische beheertypen te benoemen, vanwege praktische redenen. Er wordt in Duitsland geen onderscheid gemaakt tussen normale landbouwpraktijk en agrarisch natuurbeheer. Er is gekozen om alle gebieden te koppelen aan de agrarische typen. Dat geeft een overschatting van de agrarische typen (zie verder discussie). De abiotiek gebaseerd op de veldsituatie (zie paragraaf 2.3.4).

Voor Vlaanderen en Wallonië zijn de beschikbare vegetatiekaarten ook vertaald naar beheertypen, die vertaling is te vinden in Bijlage 4 en 5 . De gebruikte vegetatiekaarten van zowel Vlaanderen, Wallonië en Duitsland bevatten alleen informatie binnen Natura 2000-gebieden. Buiten de Natura 2000gebieden zijn de gegevens aangevuld met Corine-data (voor de vertaling van Corine-data naar beheertypen: zie Bijlage 6 en voor een beschrijving van de stappen Bijlage 8).

In totaal geeft de $15 \mathrm{~km}$-zone rondom Limburg 328721 ha extra beschouwd gebied. Als de agrarische typen buiten beschouwing worden gelaten, omdat dit vaak intensief agrarische gebieden zijn met weinig tot geen natuurwaarde en een slechte kwaliteit, blijft er 71535 ha natuur over. In Bijlage 10 zijn de oppervlakten in termen van beschouwd 'beheertype' te vinden.

\subsection{3 $\mathrm{pH}$ - en GVG-kaart Limburg}

Voor het MNP is invoer nodig van de bodem pH (in wateroplossing) en de gemiddelde voorjaargrondwaterstand (GVG) per gridcel. De pH en GVG voor de gebieden binnen het NNN zijn geschat op basis van vegetatieopnamen en ondersteunde kaarten (bodemtype, GT, vegetatietype; Wamelink et al., under review). Voor de toegevoegde gebieden binnen Limburg zijn echter geen vegetatieopnamen beschikbaar, die nodig zijn om - geheel analoog aan de methode uit de evaluatie van het Natuurpact - een schatting te maken.

Voor de $\mathrm{pH}$ is daarom aangenomen dat de condities van landschapselementen buiten NNN niet beperkend zijn voor de typen die daar volgens de kaarten voorkomen. Hiervoor is de optimale $\mathrm{pH}$ toegekend aan het gebied waar een type voorkomt (zie Tabel 1). 
Tabel $1 \quad p H$-waarden per beheertype zoals gebruikt om de optimale $p H$ en GVG te schatten voor gridcellen zonder $\mathrm{pH}$-waarde.

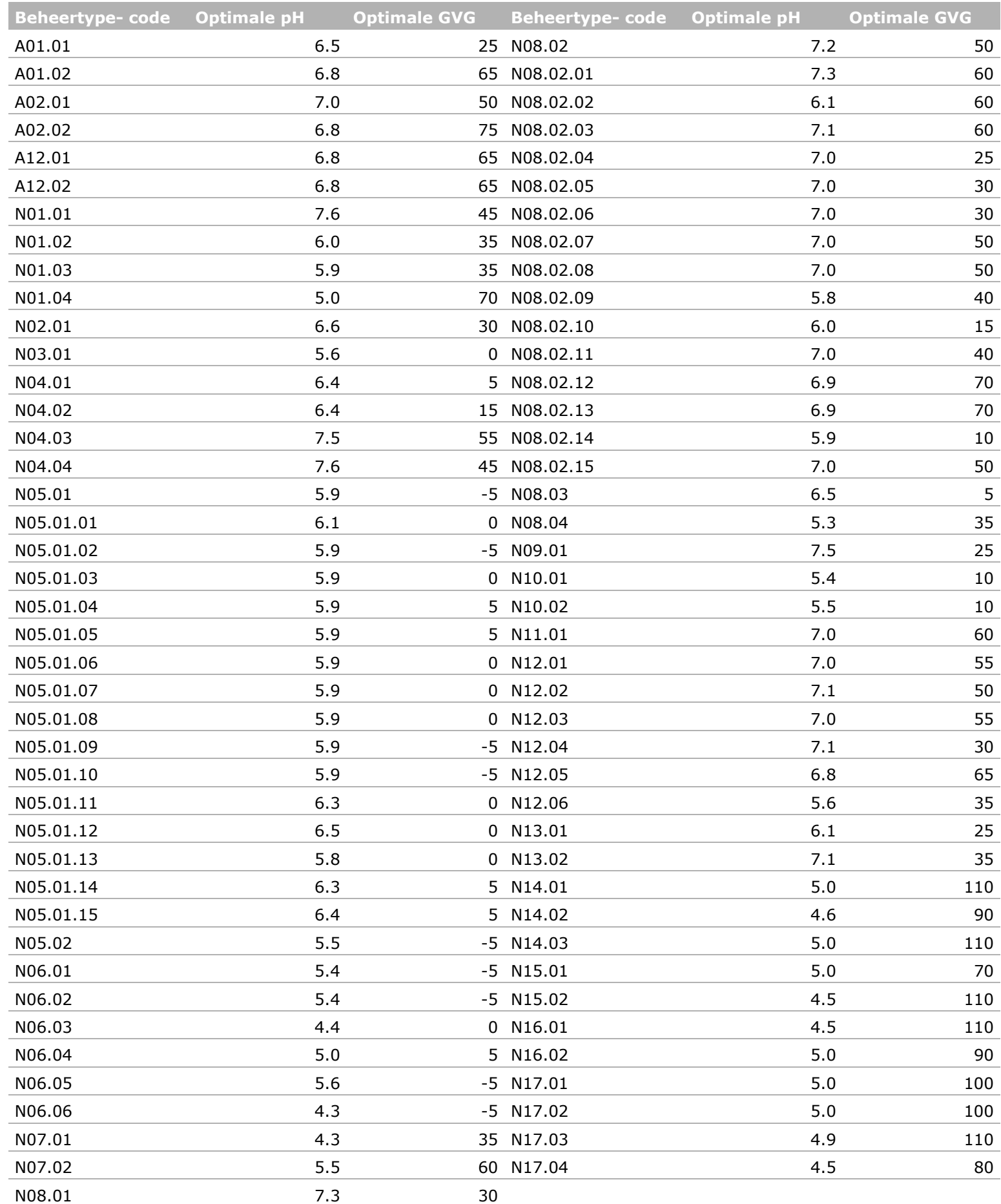

Voor de GVG is een schatting gemaakt op basis van de GT-kaart. Elke GT (hoofdcategorie) is gekoppeld aan een GVG, waarna deze vlakdekkend is toegekend (zie Tabel 2). Hierbij is de indeling volgens Kros et al. (1995, p35) gevolgd, die de elf hoofdtypen al hadden teruggebracht tot vijf hoofdtypen voor GVG. De GVG is aangepast om beter in overeenstemming te zijn met de GVG's zoals gehanteerd in het MNP. Omdat No Data in het MNP tot uitval leidt van het grid, is ervoor gekozen om de GVG daar op $150 \mathrm{~cm}$ benden maaiveld te zetten. Hierdoor is nog wel onderscheid te maken met klasse 5 (GT VII en VII*) uit Kros et al. (1995). 
Tabel 2 Gemiddelde voorjaargrondwaterstanden (GVG) bij de verschillende grondwatertrappen (GT) en klassen zoals gegeven door Kros et al. (1995).

\begin{tabular}{rlr} 
Klasse & GT & GVG (cm $-\mathrm{mv})$ \\
\hline 1 & I & 24 \\
\hline 2 & II & 48 \\
\hline 3 & II*, III, III*, V, V* \\
\hline 4 & IV, VI & 82 \\
\hline 5 & VII, VII* & 154 \\
\hline 9 & No data & 150 \\
\hline
\end{tabular}

\subsection{4 $\mathrm{pH}$ - en GVG-kaart buitenland}

Voor het schatten van de pH en GVG voor de buitenlandse gebieden is gebruikgemaakt van de optimale $\mathrm{pH}$ - en GVG-waarden van het dominante vegetatietype per $25 \mathrm{~m}^{2}$ (Tabel 1 ). Waar mogelijk zijn de vegetatieopnamen uit de Eva-database (Chytry et al., 2016; http://euroveg.org/eva-database) gebruikt. In totaal 2268 opnamen waren beschikbaar, waarvoor op basis van de soorten in de opname een GVG- en pH-waarde is geschat, conform de methode voor Nederland (zie hierboven en Wamelink et al. 2005, 2012). De pH-kaart wordt gegeven in Figuur 5 en de GVG-kaart in Figuur 6.

\subsubsection{Depositiekaart Limburg}

Voor scenario 0 en 1 is de standaard depositiekaart voor het MNP gebruikt (Figuur 7). Deze kaart op basis van OPS-berekeningen (Sauter et al., 2018) is beschikbaar voor heel Nederland en kan daarom ook gebruikt worden voor de extra typen die voor scenario 1 zijn toegevoegd aan de vegetatietypenkaart. De depositiekaart van 2016 is gebruikt (www.rivm.nl/Onderwerpen/G/GCN_GDN_kaarten/Depositiekaarten).

\subsubsection{Depositiekaart buitenland}

De depositie voor de gebieden buiten Nederland is niet beschikbaar op basis van OPS-berekeningen (of AIRIUS). Voor zowel België als Duitsland is daarom gebruikgemaakt van de EMEP-data (webdab.emep.int/Unified_Model_Results/). Deze gegevens zijn beschikbaar per 5*5km grid en dus op een grovere schaal dan voor Nederland. De depositie van het jaar 2013 is gebruikt voor scenario 2 en 3 . De kaart is gemaakt door de natte en droge deposities voor NHy en NOx bij elkaar op te tellen, wat de totale stikstofdepositie geeft. Omdat de data op een veel grovere schaal beschikbaar zijn, heeft dit invloed op de gemiddelde depositie per grid. De Nederlandse data geven een veel genuanceerder beeld (zie Figuur 7). Ook de overgangen binnen Limburg en buiten Limburg kunnen hierdoor groot zijn en niet erg realistisch (zie ook Bijlage 7).

\subsection{Koppeling soorten aan kaarten}

Bij elk beheertype hoort een lijst van soorten die daar in principe voor zouden kunnen komen. Deze lijst bestaat uit VHR- en typische soorten, aangevuld met Rode Lijst-soorten, voor zover er een goed model beschikbaar is voor het MNP. Deze lijst is voor dit project aangevuld. Voor de neergeschaalde beheertypen was nog geen definitieve soortenlijst beschikbaar, deze is aangevuld. Daarnaast zijn er nieuwe beheertypen toegevoegd voor dit project; ook hiervoor moest de typen soortenlijst worden aangevuld. De toekenning van soorten aan de typen, met bijbehorende draagkracht, is gebaseerd op de expertkennis van Bart de Knegt, Rogier Pouwels en Wieger Wamelink en de verspreidingskaarten van Sovon (vogels; www.vogelatlas.nl), Vlinderstichting (vlinders; www.vlinderstichting.nl/vlinders/overzichtvlinders) en Floron (planten; www.verspreidingsatlas.nl/vaatplanten).

Om de toekenning van de soorten aan de nieuwe typen te vergemakkelijken, is als hulpmiddel het nieuwe type zo veel mogelijk gekoppeld aan een al bestaand type met bijbehorende soortenlijst. De soortenlijst met de aanvullingen en het vooraf gekoppelde beheertype is te vinden in een digitale bijlage (verkrijgbaar bij de auteurs). 


\subsection{Modelruns en analyse}

Het MNP is gedraaid voor de vier scenario's. Daarbij is uitvoer gegenereerd per provincie, om niet alleen het landelijke effect van de Limburgse scenario's in te schatten, maar ook het effect binnen Limburg zelf. Er is gedraaid voor de VHR typische soorten set aangevuld met soorten, in totaal 280 soorten (planten, vlinders en vogels). Het effect van de scenario's op alleen de VHR typische soorten is hieruit gedestilleerd door de resultaten voor die soortengroep apart te analyseren. Om de scenario's te evalueren, worden vier uitkomsten van het MNP gebruikt:

1. Het aantal populaties in Limburg dat voor de gehele soortenset wordt voorspeld.

2. Het aantal sleutelpopulaties in Limburg dat voor de gehele soortenset wordt voorspeld

3. Het aantal soorten dat landelijk duurzaam kan voorkomen.

4. Het aantal soorten dat duurzaam kan voorkomen in Limburg.

Bij het bepalen van het aantal populaties en sleutelpopulaties worden gebieden vaak meerdere malen meegenomen, aangezien ze populaties voor meerdere soorten herbergen. Voor al deze soorten wordt één populatie toegevoegd aan het totale aantal die het MNP voorspelt, analoog aan de standaardmethode van het MNP. Sleutelpopulaties worden door het model voorspeld in grote leefgebieden met een goede kwaliteit die stabiele populaties van soorten kunnen herbergen. Deze sleutelpopulaties zijn belangrijk voor het duurzaam voorkomen van soorten (Pouwels et al., 2017; Verboom et al., 2001). 


\subsection{Duurzaam voorkomen van soorten in de provincie Limburg}

Voor de provincie Limburg zijn de MNP-resultaten voor twee soortengroepen uitgewerkt, voor VHR typische soorten met 146 gemodelleerde soorten (Tabel 3) en voor 280 VHR typische en Rode Lijstsoorten (Tabel 4). Dit zijn niet alle VHR typische soorten en Rode Lijst-soorten voor de soortgroepen broedvogels, dagvlinders en planten, maar alleen die soorten waarvoor een betrouwbaar model in het MNP beschikbaar is. De soortenlijst van 146 soorten is ook gebruikt voor de evaluatie van het Natuurpact. De focus in deze paragraaf gaat echter alleen over veranderingen in Limburg zelf en niet over veranderingen in landelijke duurzaamheid (zie daarvoor paragraaf 3.2).

Scenario 1, het toevoegen van kleine landschapselementen, heeft een groot effect op het aantal populaties, er vindt meer dan een verdubbeling plaats. Ook het aantal sleutelpopulaties, die belangrijk zijn voor het niveau van duurzaamheid, neemt toe met bijna $60 \%$. Als gevolg daarvan neemt het aantal soorten dat in Limburg duurzaam kan voorkomen toe van 18 tot 23 soorten.

In scenario 2, als het buitenland wordt meegenomen in de berekeningen, neemt het aantal populaties toe, maar het aantal sleutelpopulaties blijft min of meer gelijk (de geringe daling ligt binnen de foutenmarge van het model). Toch neemt het aantal duurzame soorten wel toe: van 18 tot 21 . Dit komt vooral door een aantal soorten die verbonden zijn aan het agrarisch gebied.

Het gecombineerde scenario 3 geeft de grootste verschillen, met bijna een verdrievoudiging van het aantal populaties en meer dan $90 \%$ toename van sleutelpopulaties voor duurzame soorten. Dit leidt tot een toename van het aantal duurzame soorten in Limburg van 18 tot 25 . Dit is $17 \%$ van de 146 soorten voor de VHR typische soorten uit de analyse.

Tabel 3 Samenvatting van de resultaten voor de drie scenario's op basis van VHR typische soorten (146 soorten) in Limburg. Met standaard landelijk (0), kleine landschapselementen (1), buitenland (2) en combinatie van scenario 1 en 2 (3) scenario's en het percentage duurzame soorten in Limburg (\%), aantal populaties, het aantal duurzame soorten, het aantal sleutelpopulaties, het percentage verandering t.o.v. scenario 0 voor het aantal sleutelpopulaties en het \% duurzame soorten.

\begin{tabular}{|c|c|c|c|c|c|c|c|}
\hline scenario & & \# populaties & $\begin{array}{l}\text { \# duurzame } \\
\text { soorten }\end{array}$ & & $\begin{array}{l}\text { \# sleutel- } \\
\text { populaties }\end{array}$ & $\begin{array}{l}\% \text { verandering } \\
\text { sleutel populaties } \\
\text { t.o.v. scenario } 0\end{array}$ & $\begin{array}{l}\% \text { duurzame } \\
\text { soorten }\end{array}$ \\
\hline & 0 & 37180 & & 18 & 5926 & & 12 \\
\hline & 1 & 85100 & & 23 & 9456 & 59.6 & 16 \\
\hline & 2 & 38597 & & 21 & 5918 & -0.1 & 14 \\
\hline & 3 & 102148 & & 25 & 11380 & 92.0 & 17 \\
\hline
\end{tabular}

Voor de bredere groep van VHR typische soorten en Rode Lijst-soorten zijn de resultaten vergelijkbaar met de VHR typische soorten alleen. Voor scenario 1 neemt het aantal populaties met ruim een factor 2 toe en het aantal sleutelpopulaties met bijna 50\%. Dit resulteert in een toename in het aantal duurzame soorten van 37 tot 47, op een totaal van 251 doorgerekende soorten die in Limburg voorkomen. Het buitenlandscenario (2) geeft een gering hoger aantal populaties en sleutelpopulaties (plus 3\%). Dit leidt net als voor de VHR typische soorten alleen wel tot een behoorlijke toename in het aantal duurzame soorten. Het combinatie scenario (3) zorgt voor de grootste toename voor het aantal 
populaties (bijna een verdrievoudiging) en het aantal sleutelpopulaties (ruim $70 \%$ ). Het aantal duurzame soorten stijgt naar 51 , wat $20 \%$ is van het aantal doorgerekende soorten.

Tabel 4 Samenvatting van de resultaten voor de drie scenario's op basis van VHR typische soorten en rode lijst soorten (280 soorten, waarvan 251 in Limburg) in Limburg. Met standaard landelijk (0), kleine landschapselementen (1), buitenland (2) en combinatie van scenario 1 en 2 (3) scenario's en het percentage duurzame soorten in Limburg (\%), aantal populaties, het aantal duurzame soorten, het aantal sleutelpopulaties, het percentage verandering t.o.v. scenario 0 voor sleutelpopulaties en het \% duurzame soorten (t.o.v. de 251 in Limburgs voorkomende soorten).

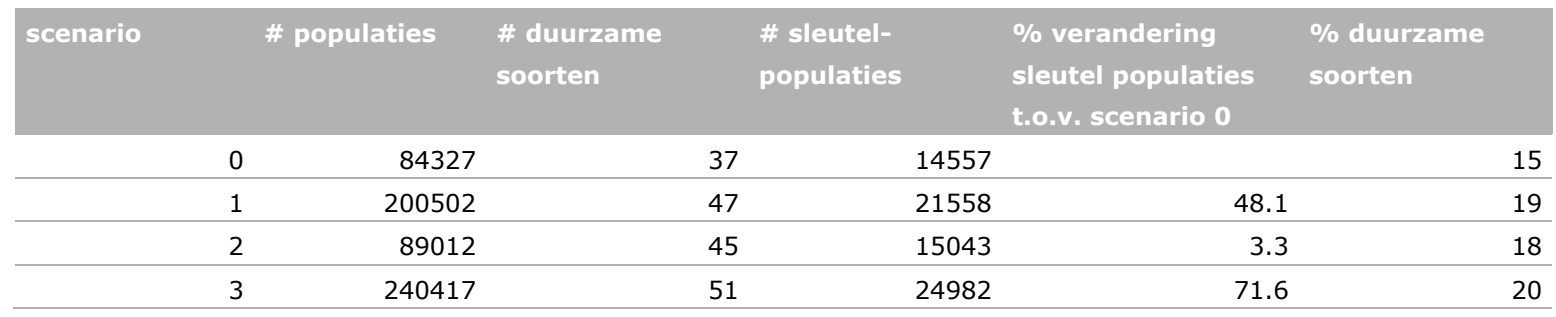

\subsection{Landelijk duurzaam voorkomen}

Het percentage soorten dat in Nederland als geheel duurzaam kan voorkomen, neemt als gevolg van het kleine landschapselementen scenario (1 in Tabel 5) voor de grote groep van VHR (typische) en Rode Lijst-soorten niet toe (280 soorten waarvan 251 doorgerekend voor Limburg). Dit zal dus ook zo zijn voor de VHR-soorten alleen. Het aantal populaties en sleutelpopulaties van de totale groep neemt wel toe, maar dat leidt niet tot een hoger percentage duurzaam voorkomende soorten voor Nederland als geheel. Dit betekent dat vooral voor de soorten die in Nederland al duurzaam kunnen voorkomen profiteren in aantal populaties en sleutelpopulaties. Voor een aantal van die soorten verbetert de situatie dus wel, maar omdat die soorten al landelijk duurzaam zijn, heeft dit geen effect op het percentage landelijk duurzaam voorkomende soorten. De groei van het aantal populaties ondersteunt de duurzaam voorkomende soorten.

Het buitenlandscenario (2) geeft ook een toename in het aantal populaties en het aantal sleutelpopulaties ten opzichte van het standaard landelijke scenario. Het aantal populaties voor het buitenlandscenario stijgt minder dan voor het kleine landschapselementenscenario. Het aantal duurzame soorten neemt met één soort toe.

Wanneer scenario 1 en 2 worden gecombineerd, nemen - zoals te verwachten viel op basis van de afzonderlijke scenario's - het aantal populaties en het aantal sleutelpopulaties toe. Ook het aantal duurzame soorten neemt hier met één soort toe.

Voor het buitenland (scenario 2 en 3 ) is niet het aantal populaties in het buitenland zelf meegenomen. Ter indicatie: als dat wel zou gebeuren, neemt het aantal duurzame soorten toe tot 144 voor scenario 2 en tot 143 voor scenario 3 . Omdat in scenario 0 het buitenland niet is meegenomen, kan geen vergelijking worden gemaakt en is het ook niet terecht om soorten die duurzaam voorkomen in het buitenland mee te tellen voor Nederland. Het wordt hier alleen vermeld als een indicatie wat extra oppervlak natuur (en agrarisch gebied) voor invloed zou hebben.

Het percentage duurzame soorten is voor alle scenario's gelijk, namelijk 50. Dit is, ook voor het landelijke 0 scenario, lager dan de 54\% die in de balans voor de leefomgeving van 2016 is gepubliceerd voor de VHR-soorten (PBL, 2016). Afwijking kan ook nog komen door de aanpassing van de neerschaling van de beheertypenkaart. Door de neerschaling ontstaan er subtypen waar de soorten aan worden toegekend. Dit levert in de regel minder oppervlak per soort op, waardoor de draagkracht van de vegetaties daalt, het aantal potentiële populaties daalt en daardoor kan de staat van instandhouding van de soorten dalen. Dit is voor een aantal soorten gebeurd, wat tot een daling van het percentage duurzame soorten leidt. Het type moeras is bijvoorbeeld in een groot aantal subtypen 
onderverdeeld, variërend van open water tot bos. Een deel van het oppervlak moeras is daardoor overgegaan naar een ander beheertype, voor andere zijn subtypen gecreëerd. Een soort die aan moeras was toegekend en daar dus in principe in het hele oppervlak kan voorkomen, is nu vaak toegekend aan een of een paar subtypen. Daardoor daalt het oppervlak voor die soort. Dat kan dan uiteindelijk leiden tot een lager percentage dat duurzaam voor kan komen in Nederland.

Het is nog onbekend of dit effect ook zal optreden voor de doorgerekende toekomstscenario's met het MNP (PBL, 2016). Maar het is waarschijnlijk dat ook hier bovengenoemd effect kan optreden en dat het percentage 'Doelbereik van duurzame soorten' op basis van alle provinciale plannen lager zal uitvallen. Op het ogenblik is er echter een discussie gaande over de neerschaling zelf; deze zal nog moeten worden gevalideerd en met name in het moeras zouden er weleens veranderingen kunnen optreden die het hier gevonden percentage van 50 weer hoger zal doen laten uitvallen. Dit wordt verder onderzocht en zal in een ander document verder worden bediscussieerd.

Tabel 5 Samenvatting van de resultaten voor de drie scenario's op basis van de grote groep van VHR typische soorten en Rode Lijst-soorten (280 soorten) voor duurzaam voorkomen in Nederland als geheel. Met standaard landelijk (0), kleine landschapselementen (1), buitenland (2) en combinatie van scenario 1 en 2 (3) scenario's en het percentage duurzame soorten in Limburg (\%), aantal populaties, het aantal duurzame soorten, het aantal sleutelpopulaties, het percentage verandering t.o.v. sc 0 voor sleutelpopulaties en het \% duurzame soorten (t.o.v. de 251 'Limburgse' soorten).

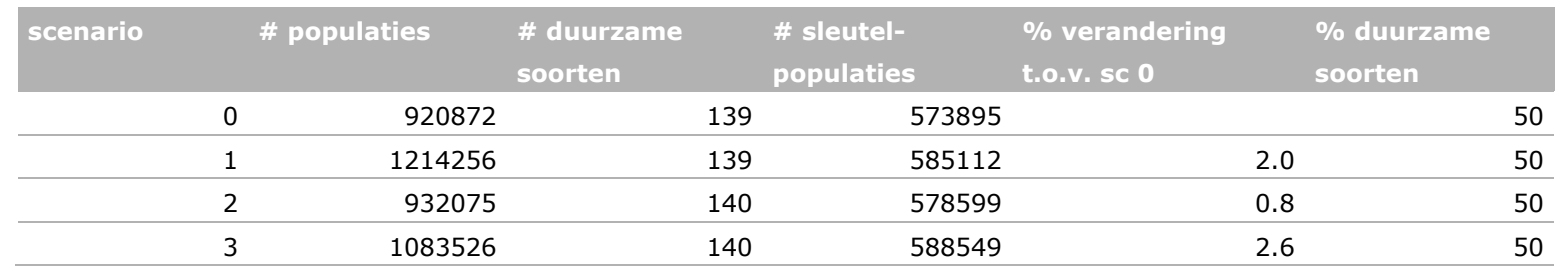




\section{Discussie}

Leeswijzer: in dit hoofdstuk worden de resultaten besproken en worden aanbevelingen gegeven. Daar waar niet verwezen wordt naar literatuur betreft het onze expertinschatting. Onderbouwing door onderzoek is dan nog gewenst. De discussie en de aanbevelingen zijn toegespitst op de vragen van de provincie en de deelnemers aan een sessie warin de eerste resultaten zijn gepresenteerd (zie Bijlage 10).

De resultaten van de MNP-berekeningen laten zien dat het toevoegen van kleine landschapselementen een behoorlijk grote toename oplevert van het aantal populaties en het aantal soorten dat duurzaam kan voorkomen binnen de provincie Limburg. Kleine landschapselementen blijken belangrijk voor biodiversiteit, Rode Lijst-soorten en VHR-soorten. De veronderstelling dat deze vaak wat kleinere gebieden niet veronachtzaamd kunnen worden, in ieder geval in Limburg, is terecht. Daarbij dient wel te worden aangetekend dat de kwaliteit van de gebieden nu goed is verondersteld; als de kwaliteit minder is, wat aannemelijk is, zullen de kleine landschapselementen minder bijdragen. Voor duurzaam voorkomen op nationaal niveau levert het meenemen van de huidige set van kleine landschapselementen buiten het NNN echter geen extra soorten op. De bestaande elementen versterken wel, maar leveren geen extra toename van het aantal duurzame soorten. Daaruit vloeit voort dat natuurbeheer en -behoud ook voor de natuurlijke gebieden buiten het NNN een versterking opleveren. Wel zijn er kanttekeningen te plaatsen bij de huidige kwaliteit van die gebieden. Dit gaat met name om de abiotiek (de stikstofdepositie, GVG en $\mathrm{pH}$ ), naast inrichting en beheer. Vaak liggen de gebiedjes ingeklemd tussen agrarische gebieden of langs wegen, met een hoge belasting door stikstofdepositie en een verlaagde grondwaterstand. Verbetering van milieucondities en/of beheer/inrichting kan leiden tot een hogere kwaliteit van die gebieden, hetgeen waarschijnlijk een positief effect zal hebben op het aantal soorten dat duurzaam kan voorkomen. Dit geldt overigens ook voor overige natuur binnen het NNN, zoals bermen, sloot- en akkerranden etc. Ook daar zouden kwaliteitsverbeteringen kunnen helpen om tot een hoger doelbereik te komen. Bovendien kan verwacht worden dat met aanpassing van beheer en/of versterking van elementen winst voor biodiversiteit en VHR-doelbereik nog is te optimaliseren. Wat het effectiefst is, ook naar kosten gekeken, kan niet uit de resultaten worden gehaald. Investeren in een goede kwaliteit in natuurgebieden, in de realisatie van nieuwe natuur die de huidige natuur versterkt en in verbindingen tussen de natuurgebieden wordt in die volgorde door Ovaskainen (2013) aangeraden om de kwaliteit te verbeteren. Dit zal echter per gebied sterk kunnen variëren. Zo hebben in de provincie Limburg sommige belangrijke natuurgebieden (zoals de Geul, het Geleenbeekdal en het Savelbos) qua vorm een grote randlengte en daardoor veel invloed van omringende agrarische dan wel stedelijke percelen. Een verbetering qua kwaliteit kan op die locaties alleen gerealiseerd worden als verbeteringen ingepast worden in de omgeving van een locatie. Om tot een goede prioritering per gebied te komen, zijn mogelijk ook andere, meer gedetailleerde, analyses noodzakelijk op standplaatsniveau (zie o.a. Wamelink et al. 2013a), maar ook naar bijvoorbeeld de dispersiecapaciteit van soorten en dus de bereikbaarheid van gebieden voor nieuwe soorten (Wamelink et al. 2013b; Wamelink et al. 2015). Het effect van bereikbaarheid - en dus dispersie van soorten - wordt niet meegenomen in het MNP. Het model bepaalt op basis van de abiotiek, het vegetatietype (beheertype) en de leefgebiedsgrootte hoeveel populaties er van een soort kunnen voorkomen. Daarbij wordt rekening gehouden met leefgebieden in de buurt. Als die tot genenuitwisseling kunnen komen worden ze beschouwd als een metapopulatie en wordt op basis daarvan berekent of een soort een of meerdere duurzame populaties kan vormen in het gebied. De dispersieafstand speelt daarbij wel een rol, maar er wordt geen rekening mee gehouden of een soort ook daadwerkelijk ergens aanwezig is en van daaruit een andere plek kan bereiken. Daarom zijn de resultaten van de MNP-potenties op basis van condities en dus ook het potentieel duurzaam voorkomen op basis van condities. De realisatie hangt mede af van andere factoren, waaronder dispersie, maar ook daadwerkelijk uitgevoerd beheer. Het model doet dit voor drie soortgroepen, planten, vlinders en vogels, die als proxy worden gebruikt voor de kwaliteit van de natuur en het duurzaam voorkomen van soorten (zie verder Pouwels et al., 2016b). 
Natuur in het buitenland heeft ook effect op het aantal populaties en het aantal duurzaam voorkomende soorten binnen Limburg. Het effect is echter veel beperkter dan het effect van de kleine landschapselementen. Grensoverschrijdende natuur maakt het oppervlak natuur groter, waardoor populaties, samen met de buitenlandse natuur, eerder als stabiele populatie worden aangemerkt in het Limburgse deel van die grensoverschrijdende natuur. Hierdoor kan ook in Limburg zelf het aantal duurzaam voorkomende soorten toenemen. Het gecombineerde scenario laat de grootste stijging zien voor Limburg. Dit geeft aan dat zowel het buitenland als kleine landschapselementen een bijdrage leveren aan biodiversiteit en de natuurdoelen die in de NNN worden nagestreefd in Limburg. Daarom concluderen wij dat wanneer het belang van Limburg voor het behoud van de soorten van de VHR wordt bepaald met een model als het MNP, het buitenland moet meegenomen worden om een evenwichtige vergelijking te kunnen maken met provincies die niet grenzen aan België en/of Duitsland, bijvoorbeeld Utrecht. Daarbij mogen uiteraard alleen de in Nederland gerealiseerde condities voor (duurzame) populaties worden meegenomen in de berekeningen.

Als de resultaten van de scenario's op landelijk niveau worden geanalyseerd, komt er een ander beeld naar voren. Het effect van de scenario's op het aantal populaties is vergelijkbaar met de resultaten voor Limburg, zoals mocht worden verwacht. Echter, het aantal soorten dat duurzaam kan voorkomen in Nederland verandert niet wezenlijk door het in beschouwing nemen van landschapselementen en het buitenland. Dit komt omdat de soorten die in Limburg zelf duurzaam worden in Nederland al duurzaam voorkwamen. Het toevoegen van kleine landschapselementen en het buitenland rondom Limburg geeft alleen verandering voor duurzaamheid binnen Limburg zelf. Daarnaast is er natuurlijk winst voor biodiversiteit: er komen meer soorten voor op meer plekken.

De verandering gaat echter om soorten en vegetatietypen waar in Nederland al genoeg oppervlak van is om die soorten duurzaam in stand te houden. De groei in de niet duurzame soorten is niet groot genoeg om duurzaamheid te realiseren. Dat is een niet geheel onverwacht resultaat, omdat kleine landschapselementen vaak natuur betreffen met een lagere kwaliteit en oppervlakte en vaak liggen de elementen versnipperd. Dit effect werd ook gevonden in een studie voor de provincie Noord-Holland, waar in een scenario rond alle weilanden en akkergebieden een strook van 3 meter bloemrijk grasland werd gelegd. Pas het toevoegen van grote oppervlakten natuur (het hele veenweidegebied) leverde grote verbeteringen op (Wamelink et al., 2017).

Voor scenario 1 zijn verschillende typen natuur toegevoegd voor Limburg. Veel van die natuurelementen zijn kleine landschapselementen met een onzekere kwaliteit, zowel wat betreft vegetatietype (vorm, beheer en inrichting) als abiotiek. In overleg met de provincie Limburg zijn er relatief hoog kwalificerende $\mathrm{N}$-typen (natuurtypen met een uitgebreide soortenlijst en ook relatief hoge eisen voor de bodemkwaliteit) toegekend aan de elementen. Wegbermen e.d. hebben natuurtypen gekregen, daar waar mogelijk een agrarisch type of een landschapselementtype beter had gepast. Dit leidt mogelijk tot een overkwalificatie van de toegevoegde typen met bijbehorende soorten. Dit kan geleid hebben tot een overschatting van de bijdrage van de toegevoegde kleine landschapselementen. Of dit daadwerkelijk is gebeurd, zou nader uitgezocht kunnen worden. De abiotiek (GVG en pH) is voor de toegevoegde kleine landschapselementen onbekend omdat ze, per definitie, buiten het NNN liggen. Daarom is aangenomen dat pH en GVG niet beperkend (optimaal) zijn voor de vegetatietypen. Deze standaardprocedure in het gebruik van het MNP leidt ook tot een overschatting. Hoe groot de overschatting in het scenario van het meenemen van de kleine landschapselementen is, is onbekend, maar waarschijnlijk wel aanwezig en heeft betrekking op de uitkomsten van scenario 1 en 3 . Het abiotische gedeelte van de overschatting is wel op te lossen door de $\mathrm{pH}$-kaart en de GVG-kaart voor Nederland opnieuw te schatten, inclusief de kleine landschapselementen. Het toekennen van de typen zal altijd een kwestie van interpretatie blijven, met uitzondering van de L-typen, welke vastgelegd zijn. Bij het landelijk toevoegen van de kleine landschapselementen zal hier nader naar gekeken moeten worden en zal de relatief hoge kwaliteitstoekenning voor de landschapselementen niet zonder meer van Limburg kunnen worden overgenomen.

Voor scenario 1 en 3 is voor het eerst met de Landschapstypen van de SNL met het MNP gerekend. Daarvoor zijn soorten gekoppeld aan de landschapstypen (deze worden niet gegeven door de SNL, op een paar uitzonderingen na). Daarnaast zijn er nieuwe typen toegevoegd met nieuwe soorten. Het koppelen van de soorten aan de L-typen en aan de toegevoegde typen is nog niet door onafhankelijke 
experts geëvalueerd. Dit wordt ten zeerste aanbevolen, waarbij er ook aandacht zou moeten zijn voor de al bestaande soortenlijsten per natuurtypen. Recentelijk is er discussie ontstaan over met name de wijze waarop het type Moeras wordt meegenomen in de MNP-analyses. Samen met Open duin is dit type neergeschaald om meer onderscheid te kunnen maken in subtypen. Voor moeras staat een deel van de neerschaling ter discussie. Omdat in Limburg moeras een kleine rol speelt, zal het effect op de uitkomsten van dit onderzoek niet erg groot zijn. Het is er wel de oorzaak van dat nu voor het standaardscenario een doelbereik van $50 \%$ wordt gevonden in plaats van $54 \%$ (PBL, 2016). Door de neerschaling is het oppervlak natuur voor een aantal soorten kleiner geworden (zie ook paragraaf 3.2).

Bij het toekennen van de beheertypen in het buitenland zijn ook alle agrarische gebieden toegekend aan een van de agrarische beheertypen. In Nederland is dat alleen het geval als er een beheerspakket in het kader van de SNL aan gekoppeld is. Omdat de SNL niet geldt in het buitenland en onbekend is of er speciaal voor een soort beheerd wordt, is ervoor gekozen om al het agrarisch gebied te koppelen aan een agrarisch type. Dat geeft een overschatting van de typen en hun oppervlak. Dat is ook zichtbaar in de kaart (Figuur 4), waar behalve de bebouwde gebieden al het oppervlak een natuurtype heeft gekregen. Dit geeft een overschatting t.o.v. van wijze waarop het landelijk gebied in Nederland wordt meegenomen en daarmee tevens een overschatting van de invloed van het meenemen van het buitenland op het aantal duurzame soorten in Nederland. Omdat de kwaliteit van de agrarische gebieden veelal slecht is qua stikstofdepositie, GVG en pH, zal de draagkracht van die gebieden laag zijn, zeker voor planten en vlinders. Daardoor is de overschatting minder dan wanneer er goede kwaliteit zou worden verondersteld. Alleen voor vogels zou er wel een positief effect kunnen zijn. In een volgende studie zou dit effect teniet kunnen worden gedaan door de agrarische gebieden niet mee te nemen, wat mogelijk dan wel tot een onderschatting kan leiden. De overschatting heeft betrekking op de uitkomsten van scenario 2 en 3.

Voor de verschillende scenario's neemt het aantal beschermde soorten in Limburg toe. Het zou interessant kunnen zijn om te onderzoeken welke soorten dit zijn en of ze tot een bepaalde categorie behoren. De onzekerheden in de individuele soortvoorspellingen zijn echter vrij groot. Daarom is een betrouwbare analyse op soort- en provincieniveau niet mogelijk en worden resultaten voor individuele soorten niet gepubliceerd. Voor scenario 1 zijn er een vogelsoort, een vlindersoort en acht plantensoorten die van niet duurzaam naar duurzaam gaan. Daar zit geen typisch Limburgse soort bij. Dat het vooral plantensoorten zijn, was te verwachten; ten eerste omdat ze getalsmatig in de overhand zijn in het MNP en ten tweede omdat er vooral kleine stukjes natuur zijn toegevoegd bij scenario 1. Plantensoorten hebben gemiddeld minder oppervlak nodig dan vlinders, en zeker vogels, dus was de verwachting dat voor plantensoorten het effect het grootst zou zijn.

\section{Aanbevelingen}

Het onderzoek laat duidelijk zien dat het toevoegen van kleine landschapselementen, en in mindere mate het meenemen van het buitenland, een positief effect heeft op het duurzaam kunnen voorkomen van soorten in Limburg, maar dat er landelijk geen toename is. Een belangrijke vraag blijft dan ook welke strategie gevolgd moet worden om een hoger doelbereik te realiseren. Daarvoor zijn wel een aantal richtingen te geven, maar deze zullen onderbouwd moeten worden met gerichte analyses en uiteindelijk mogelijk zelfs door plaatselijk onderzoek. Daarbij zal ook gekeken moeten worden naar de abiotische kwaliteit van de natuurgebieden, die ook verder gaat dan alleen de GVG en de pH (Wamelink et al., 2012, 2013a).

Waar op korte termijn in Limburg aan gewerkt zou kunnen worden, is:

1. Het verbeteren van de abiotiek van natuur in NNN voor de factoren die door de provincie te beïnvloeden zijn (Lerende evaluatie, Folkert \& Boonstra, 2017). Dit kan deels via het uitvoeren van brongerichte of effectgerichte maatregelen in het kader van bijvoorbeeld de Programmatisch Aanpak Stikstof (PAS) in Natura 2000-gebieden. Vaak wordt dit ook via de verandering van grondwaterstand gerealiseerd. Dit zou ook kunnen worden toegepast in andere natuurgebieden in Limburg, dus in de overige NNN-gebieden en daarbuiten. Het voordeel is dat er vaak nog veel winst te behalen valt in bestaande natuurgebieden, waarbij er geen kosten voor aankoop van gronden gemaakt hoeft te worden. Het betreft echter vaak complexe oplossingen, zoals de aanpak van de grondwaterstand (daar waar van toepassing) of de stikstofdepositie. Het aanpakken van 
deze knelpunten heeft ook invloed op omringende gronden die in gebruik zijn voor landbouw of bewoning/industrie. Een hogere grondwaterstand kan het telen van sommige gewassen bijvoorbeeld negatief beïnvloeden en voor problemen zorgen in woonwijken. Het terugdringen van de stikstofdepositie vergt ingrijpende maatregelen in het landbouwsysteem en/of industrie en wegverkeer.

2. Het nastreven van hogere ambities, door de 7000 ha recentelijk gerealiseerde natuur in de categorie kruidenrijk grasland om te zetten naar voor VHR-doelstellingen hoogwaardigere beheertypen. Dit kunnen graslanden zijn, zoals kamgraslanden of schraalgraslanden (kalkrijk), maar ook heide of bossen (de loofbossen in Limburg kunnen zeer bijzondere vegetatie bevatten; Hommel et al., 2016). Dit zou relatief makkelijk te realiseren kunnen zijn. Een kanttekening hierbij is dat met het realiseren van 'hoogwaardigere' beheertypen ook hogere eisen aan de kwaliteit met betrekking tot stikstofdepositie, GVG en pH gesteld worden. De vraag is in hoeverre dit mogelijk is.

3. Het omvormen van landbouwgrond naar 'hoogwaardige' beheertypen. Het gaat conform de huidige planning van de provincie Limburg om 1340 ha. Ook hier is de vraag of de vereiste omgevingskwaliteit kan worden bereikt.

4. Opwaarderen van 750 ha bestaand kruidenrijk grasland binnen de NNN en functieverandering van 750 ha landbouwgrond naar hoogwaardige natuur ten bate van het robuuster maken van N2000gebieden. Dit zou veranderingen vergen binnen de doelstellingen en vegetatietypen binnen het NNN. Een deel van de kruidenrijke graslanden opwaarderen om voor andere soorten een duurzaam bestaan in Limburg te creëren, zou mogelijk kunnen zijn.

Voor alle vier de opties geldt dat de uiteindelijke omgevingskwaliteit die gerealiseerd wordt, bepaalt hoeveel soorten daar kunnen voorkomen en hoeveel die kunnen bijdragen aan het duurzaam voorkomen van soorten. Modelmatig gaat het dan om de GVG, pH en stikstofdepositie als abiotische randvoorwaarden en de ruimtelijke samenhang. In het veld zullen daar nog ander abiotische randvoorwaarden bijkomen, zoals fosfaat, kalium en het calciumgehalte. Ook de aanwezigheid van zaden in de zaadbank of binnen dispersieafstand zal bepalend zijn. Zeer belangrijk is ook dat het juiste beheer wordt toegepast, bijvoorbeeld in wegbermen, wat vaak (veel) natuurvriendelijker kan. Tevens is het mogelijk om na te gaan in welke regio's het verbeteren van condities op landschapsschaal door middel van het stimuleren van bijvoorbeeld natuurinclusieve landbouw een bijdrage kan leveren aan het realiseren van een hoger doelbereik (Verweij et al., 2017). Het is voor de provincie Limburg ook aan te raden om te bepalen voor welk type soorten en welke soorten ze aan de slag wil en waar deze soorten actueel voorkomen. Voor het duurzaam voorkomen van soorten heeft het niet heel veel zin om het natuurbehoud te richten op soorten die in Limburg of landelijk al duurzaam voorkomen. Dit zouden bij voorkeur typisch Limburgse soorten zijn die nauwelijks of niet buiten Limburg voorkomen, zoals de soorten van de kalkgraslanden en de hellingbossen. Voor de selectie van soorten en vegetatietypen zal nader onderzoek moeten worden gedaan. De keuze van de selectie en inrichting van nieuwe natuurgebieden en de verandering van bestaande natuurgebieden (bijvoorbeeld van bloemrijk grasland naar kalkgrasland) kunnen met de MNP-scenario's doorgerekend worden, om zo de verschillende opties te evalueren. Hiervoor zal het noodzakelijk zijn om de geplande en gewenste vegetatietypen op kaart te hebben. Daarbij kunnen ook andere data betrokken worden, zoals de recentelijk ontwikkelde abiotische kaarten voor Nederland (Wamelink et al., under review).

Om een advies te kunnen geven dat langere tijd stand zal houden, is het goed om de effecten van klimaatverandering mee te nemen. Het MNP is recentelijk aangepast om het directe effect van de temperatuur op de soorten te modeleren. Daarnaast kan het effect van verandering in neerslag verwerkt worden in de GVG. Daarvoor zullen standaard scenario's van het KNMI vertaald moeten worden naar GVG. Daarnaast zou er doorgerekend kunnen worden wat het effect is als er aanvullend landbouwgebieden uit productie worden gehaald en omgevormd worden naar natuur, bijvoorbeeld langs de beken en rivieren in Limburg. 


\section{Literatuur}

Chytry et al., 2016. European Vegetation Archive (EVA): an integrated database of European vegetation plots. Applied Vegetation Science 19: 173-180.

Carignan, V., \& Villard, M.A., 2002. Selecting indicator species to monitor ecological integrity: A review. Environmental Monitoring and Assessment, 78(1), 45-61.

Eglington, S.M., D.G. Noble and R.J. Fuller, 2012. A meta-analysis of spatial relationships in species richness across taxa: Birds as indicators of wider biodiversity in temperate regions. Journal for Nature Conservation 20: 301-309.

Folkert, R. \& Boonstra, F., 2017. Lerende evaluatie van het Natuurpact. Naar nieuwe verbindingen tussen natuur, beleid en samenleving. PBL Planbureau voor de Leefomgeving, Den Haag. PBLpublicatienummer: 1769.

P.W.F.M. Hommel, Bijlsma, R.J. Eichhorn, K.A.O., Ouden, J. den, Waal, R.W. de, Wallis de Vries, M.F., 2016. Mogelijkheden voor herstelbeheer in hellingbossen op kalkrijke bodem in Zuid-Limburg. Resultaten praktijkproeven: omvorming van voormalig middenbos naar gevarieerd opgaand bos. VBNE, Vereniging van Bos- en Natuurterreineigenaren, Rapport nr. 2016/OBN206-HE.

Ovaskainen, O., 2013. How to develop the Nature Conservation Strategies for the Netherlands? De Levende Natuur. 114, 2, p. 59-62.

PBL, 2016. Balans voor de Leefomgeving 2016. Richting geven - Ruimte maken. Bilthoven, PBL.

Pouwels, R., M. van Eupen, M.H.C. van Adrichem, B. de Knegt \& J.G.M. van der Greft, 2016. MetaNatuurplanner v2.0; Status A. WOt-technical report 64. Wettelijke Onderzoekstaken Natuur \& Milieu.

Pouwels, R., W.G.M. van der Bilt, A. van Hinsberg, B. de Knegt, R. Reijnen, J. Verboom, en L.M. Jones-Walters, 2016b. Assessing biodiversity change in scenario studies: introducing a decision support tool for analysing the impact of nature policy. WOt paper 39. WOT Natuur \& Milieu, Wageningen UR, Wageningen.

Pouwels, R., Wamelink, G.W.W., Adrichem, M.H.C. van, Jochem, R., Wegman, R.M.A. \& Knegt, B. de, 2017. MetaNatuurplanner v4.0 - Status A; toepassing voor Evaluatie Natuurpact. Wettelijke Onderzoekstaken Natuur \& Milieu, WOt-technical report 110.

Sauter et al., 2018. The OPS-model. Description of OPS 4.5.2. www.rivm.nl/media/ops/v4.5.2/OPSmodel-v4.5.2.pdf.

Sierdsema, H., van Diermen, J., Aarts, B.G.W., Bremer, L. and van Kleunen, A., 2008. Factsheets van broedvogels in de Natura 2000-gebieden van Gelderland. SOVON Vogelonderzoek Nederland.

Sierdsema, H., R. Wolf, A. van Kleunen, Loes van den Bremer, Laurens Sparrius, John Smit, Adriaan Gmelig Meyling, Tim Termaat, Jan Kranenbarg, Hans Hollander \& Ronald Zollinger, 2015. Leefgebiedkaarten van de Gelderse Natura2000-gebieden. Sovon-rapport 2015/67. Sovon Vogelonderzoek Nederland, Nijmegen.

Terell, J.W., McMahon, T.E., Inskip, P.D., Raleigh, R.F. and Williamson, K.L., 1982. Habitat suitability index model. Guidelines for riverine and lacustrine applications of fish HSImodels with the Habitat Evaluation Procedure. Washington DC: US Fish and Wildlife Service.

US Fish and Wildlife Service, 1981. Standards for the Development of Habitat Suitability Index Models for Use with the Habitat Evaluation Procedures. US Fish and Wildlife Service.

Van Beek, J.G., R.F. van Rosmalen, B.F. van Tooren \& P.C. van der Molen, 2014. Werkwijze Monitoring en Beoordeling Natuurnetwerk en Natura 2000/PAS, Utrecht: BIJ12.

Verbrugge, L.N.H., L. de Hoop, R.S.E.W. Leuven, R. Aukema, R. Beringen, R.C.M. Creemers, G.A. van Duinen, H. Hollander, M. Scherpenisse, F. Spikmans, C.A.M. van Turnhout, S. Wijnhoven \& E. de Hullu, 2015. Expertpanelbeoordeling van (potentiële) risico's en managementopties van invasieve exoten in Nederland: Inhoudelijke input voor het Nederlandse standpunt over de plaatsing van soorten op EU-verordening 1143/2014. Verslagen Milieukunde nr. 486. Radboud Universiteit Nijmegen, Nijmegen. 
Verweij, P.J.F.M., Frissel, J.Y., Jochem, R. \& Pouwels, R., 2017. Onderbouwing locaties en additionele maatregelen ten behoeve van Natuurbeleid Gelderland. Wageningen, Wageningen Environmental Research-rapport 2847.

Wamelink, G.W.W, Goedhart, P.W., Dobben, H.F van \& Berendse, F., 2005. Plant species as predictors of soil $\mathrm{pH}$ : replacing expert judgement by measurements. Journal of vegetation science 16:461-470.

Wamelink, G.W.W., Adrichem, M.H.C. van, Dobben, H.F. van, Frissel, J.Y., Held, M. den, Joosten, V., Malinowska, A.H., Slim, P.A. \& Wegman, R.J.M., 2012. Vegetation relevés and soil measurements in the Netherlands; a database. Biodiversity and Ecology 4:125-132.

Wamelink, G.W.W., Knegt, B. de, Pouwels, R., Schuiling, C., Wegman, R.M.A., Schmidt, A.M., Dobben, H.F. van, Sanders, M.E., 2013a. Considerable environmental bottlenecks for species listed in the Habitats and Birds Directives in the Netherlands. Biological Conservation 165: $43-53$.

Wamelink, G.W.W., R. Pouwels, R.M.A. Wegman, M.H.C. van Adrichem en M. van Eupen, 2013 b. Effecten van het aanpassen van de EHS in de provincie Limburg. Wageningen, Alterra, Alterrarapport 2417.

Wamelink, Wieger, Wegman, Ruut, Schuiling, Rini \& Woltjer, Inez, 2015. Validatie van de vegetatiestructuurkaart. Interne notitie. Wettelijke Onderzoekstaken Natuur \& Milieu.

Wamelink, G.W.W., R. Jochem, J.G.M. van der Greft-van Rossum, J. Franke, A.H. Malinowska, W. Geertsema, A.H. Prins, W.A. Ozinga, D.C.J. van der Hoek \& C.J. Grashof-Bokdam, 2015. DIMO, a plant dispersal model. Wageningen, WOT Natuur \& Milieu, WOt-paper 37. http://edepot.wur.nl/335925.

Wamelink, Wieger, Rogier Pouwels, Bart de Knegt, Marjolein van Adrichem \& Rene Jochem, 2017. Biodiversiteit in Noord-Holland. Wat leveren verschillende grootschalige/landschappelijke ingrepen aan biodiversiteitswinst op? Intern document. Alterra, Wageningen.

Wamelink, G.W.W., Walvoort, D.J.J., Meeuwsen, H.A.M., Wegman, R.M.A., Sanders, M.E., Pouwels, R. \& Knotters, M., under review. Prediction of the soil pH patterns in nature areas on a national scale. Applied Vegetation Science.

Wolters, V., Bengtsson, J., \& Zaitsev, A.S., 2006. Relationship among the species richness of different taxa. Ecology, 87(8), 1886-1895. 


\section{Bijlage 1 Beheertypen gebruikt binnen het project}

De lijst is inclusief de landschapselementen (L-typen), de agrarische typen (A-typen), neergeschaalde beheertypen (voor N05.01, moeras en N08.02 open duin) en de door ons toegevoegde typen (S en T voor stad en W-typen voor overige typen), inclusief typfouten.

\begin{tabular}{|c|c|}
\hline Beheertype & Naam \\
\hline 0 & 0 Geen \\
\hline A01.01 & A01.01 Weidevogelgebied \\
\hline A01.02 & A01.02 Akkerfaunagebied \\
\hline A01.03 & A01.03 Ganzenfoerageergebied \\
\hline A01.04 & A01.04 Insectenrijk grasland \\
\hline A01.05 & A01.05 Foerageerrand bever \\
\hline A02.01 & A02.01 Botanisch waardevol grasland \\
\hline A02.02 & A02.02 Botanisch waardevol akkerland \\
\hline A11.01 & A11.01 Weidevogelgrasland in open landschap \\
\hline A11.02 & A11.02 Weidevogelland met riet of opgaande begroeiing \\
\hline A11.03 & A11.03 Open grasland voor overwinterende vogels \\
\hline A12.01 & A12.01 Open akkerland voor broedende akkervogels \\
\hline A12.02 & A12.02 Open akkerland voor overwinterende akkervogels \\
\hline A12.03 & A12.03 Akkerland met hamsters \\
\hline A13.01 & A13.01 Bomenrij en singel \\
\hline A13.02 & A13.02 Struweel en ruigte \\
\hline A14.01 & A14.01 Watergang \\
\hline A14.02 & A14.02 Poel \\
\hline L01.01 & L01.01 Poel en kleine historische wateren \\
\hline L01.02 & L01.02 Houtwal en houtsingel \\
\hline L01.03 & L01.03 Elzensingel \\
\hline L01.04 & L01.04 Bossingel en bosje \\
\hline L01.05 & L01.05 Knip- of scheerheg \\
\hline L01.06 & L01.06 Struweelhaag \\
\hline L01.07 & L01.07 Laan \\
\hline L01.08 & L01.08 Knotboom \\
\hline L01.09 & L01.09 Hoogstamboomgaard \\
\hline L01.10 & L01.10 Struweelrand \\
\hline L01.11 & L01.11 Hakhoutbosje \\
\hline L01.12 & L01.12 Griendje \\
\hline L01.13 & L01.13 Bomenrij of solitaire boom \\
\hline L01.14 & L01.14 Rietzoom en klein rietperceel \\
\hline L01.15 & L01.15 Natuurvriendelijk oever \\
\hline L01.16 & L01.16 Bossingel \\
\hline L02.01 & L02.01 Fortterrein \\
\hline L02.02 & L02.02 Historisch bouwwerk en erf \\
\hline L02.03 & L02.03 Historische tuin \\
\hline L03.01 & L03.01 Aardwerk en groeve \\
\hline L04.01 & L04.01 Wandelpad over boerenland \\
\hline N00.01 & N00.01 Nog om te vormen landbouwgrond naar natuur (inrichting) \\
\hline N00.02 & N00.02 Nog om te vormen natuur naar natuur (functieverandering) \\
\hline N01.01 & N01.01 Zee en wad \\
\hline N01.02 & N01.02 Duin- en kwelderlandschap \\
\hline N01.03 & N01.03 Rivier- en moeraslandschap \\
\hline N01.04 & N01.04 Zand- en kalklandschap \\
\hline N02.01 & N02.01 Rivier \\
\hline N03.01 & N03.01 Beek en Bron \\
\hline
\end{tabular}




\begin{tabular}{|c|c|}
\hline Beheertype & Naam \\
\hline N04.01 & N04.01 Kranswierwater \\
\hline N04.02 & N04.02 Zoete Plas \\
\hline N04.03 & N04.03 Brak water \\
\hline N04.04 & N04.04 Afgesloten zeearm \\
\hline N05.01 & N05.01 Moeras \\
\hline N05.01.01 & N05.01.01 Krabbescheervelden \\
\hline N05.01.02 & N05.01.02 Landriet \\
\hline N05.01.03 & N05.01.03 Waterriet \\
\hline N05.01.04 & N05.01.04 Hoge zeggen en biezen \\
\hline N05.01.05 & N05.01.05 Veenmosrietland \\
\hline N05.01.06 & N05.01.06 Moerasstruweel \\
\hline N05.01.07 & N05.01.07 Moerasloofbos \\
\hline N05.01.08 & N05.01.08 Moerasnaaldbos \\
\hline N05.01.09 & N05.01.09 Laagveen \\
\hline N05.01.10 & N05.01.10 Hoogveenbos \\
\hline N05.01.11 & N05.01.11 Galigaanmoerassen \\
\hline N05.01.12 & N05.01.12 Kalktufbronnen en kalkmoerassen \\
\hline N05.01.13 & N05.01.13 Open zand \\
\hline N05.01.14 & N05.01.14 Slikkige rivieroever \\
\hline N05.01.15 & N05.01.15 Nat hakhout \\
\hline N05.02 & N05.02 Gemaaid rietland \\
\hline N06.01 & N06.01 Veenmosrietland en moerasheide \\
\hline N06.02 & N06.02 Trilveen \\
\hline N06.03 & N06.03 Hoogveen \\
\hline N06.04 & N06.04 Vochtige heide \\
\hline N06.05 & N06.05 Zwakgebufferd ven \\
\hline N06.06 & N06.06 Zuur ven en hoogveenven \\
\hline N07.01 & N07.01 Droge heide \\
\hline N07.02 & N07.02 Zandverstuiving \\
\hline N08.01 & N08.01 Strand en embryonaal duin \\
\hline N08.02 & N08.02 Open duin \\
\hline N08.02.01 & N08.02.01 Zeereep en strand \\
\hline N08.02.02 & N08.02.02 Stuivend duinzand \\
\hline N08.02.03 & N08.02.03 Witte duinen \\
\hline N08.02.04 & N08.02.04 Nat en vochtig duingrasland \\
\hline N08.02.05 & N08.02.05 Vochtig duinvallei (kalkrijk) \\
\hline N08.02.06 & N08.02.06 Vochtig duinvallei (ontkalkt) \\
\hline N08.02.07 & N08.02.07 Droog duingrasland kalkrijk \\
\hline N08.02.08 & N08.02.08 Droog duingrasland kalkarm \\
\hline N08.02.09 & N08.02.09 Droge Duinruigte \\
\hline N08.02.10 & N08.02.10 Duinriet \\
\hline N08.02.11 & N08.02.11 Duinstruweel \\
\hline N08.02.12 & N08.02.12 Duinnaaldbos \\
\hline N08.02.13 & N08.02.13 Duinloofbos \\
\hline N08.02.14 & N08.02.14 Vochtige duinheide \\
\hline N08.02.15 & N08.02.15 Duingrasland \\
\hline N08.03 & N08.03 Vochtige duinvallei \\
\hline N08.04 & N08.04 Duinheide \\
\hline N09.01 & N09.01 Schor of kwelder \\
\hline N10.01 & N10.01 Nat schraalland \\
\hline N10.02 & N10.02 Vochtig hooiland \\
\hline N11.01 & N11.01 Droog schraalgrasland \\
\hline N12.01 & N12.01 Bloemdijk \\
\hline N12.02 & N12.02 Kruiden- en faunarijk grasland \\
\hline N12.03 & N12.03 Glanshaverhooiland \\
\hline N12.04 & N12.04 Zilt- en overstromingsgrasland \\
\hline N12.05 & N12.05 Kruiden- of faunarijke akker \\
\hline N12.06 & N12.06 Ruigteveld \\
\hline
\end{tabular}




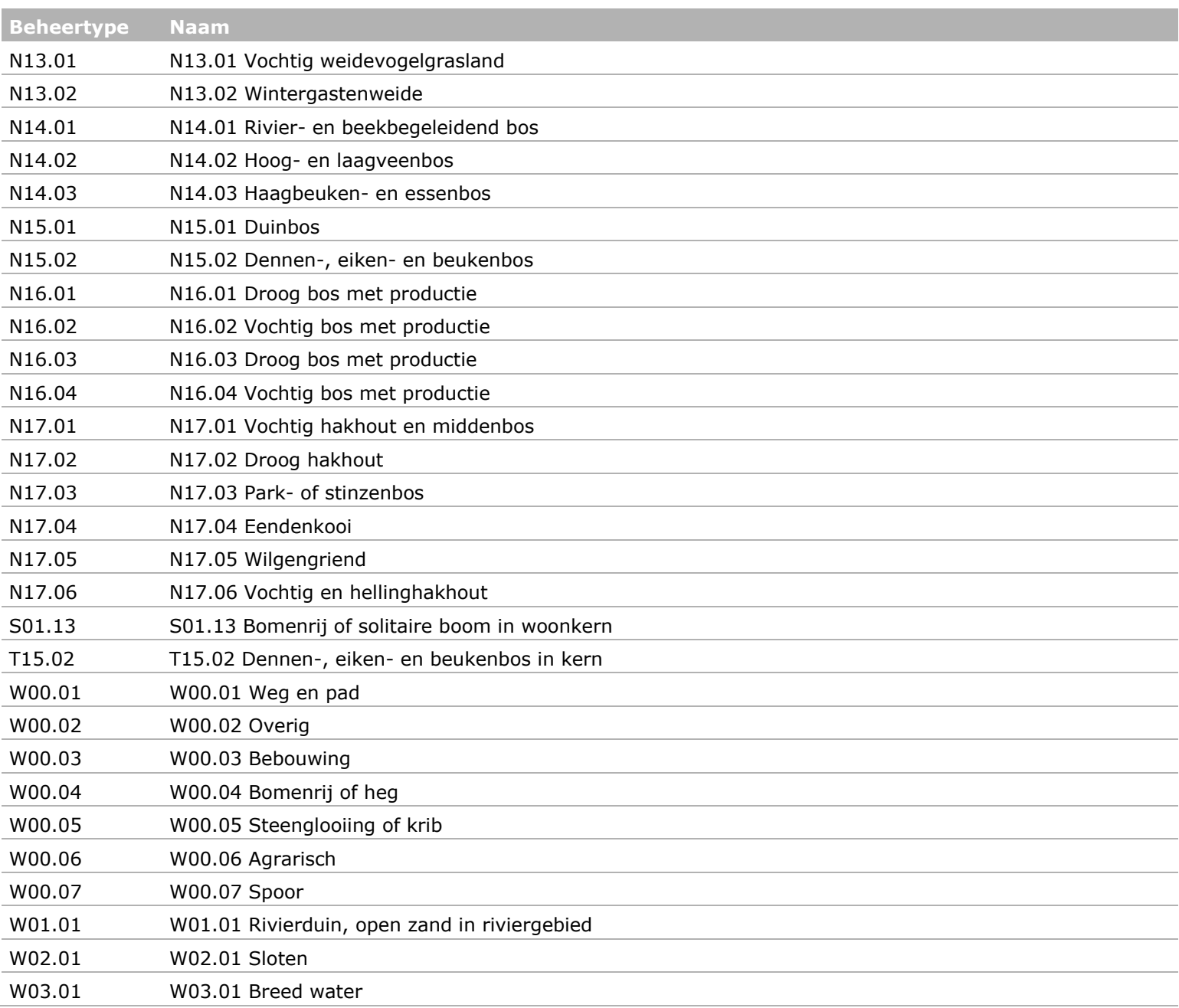




\section{Bijlage 2 Extra vegetatietypen binnen Limburg}

De vegetatiekartering is in eerste instantie in drie afzonderlijke bestanden aangeleverd: een oudere kartering in een vlakkenbestand met de naam Kart2_91_07_Vlakken_SBB_MTN_Kart1, een lijnenbestand met de naam Kart2_91_07_Lijnen_MTN, en een recentere kartering in veg_r3_2016. Het laatste bestand is niet dekkend voor de hele provincie en aangezien er nog wat andere nadelen aan dit bestand kleefden, is in onderling overleg besloten dit bestand niet te gebruiken. Het aantal kolommen en de kolomnamen in de twee andere bestanden variëren nogal, maar alleen de onderstaande kolommen waren van belang:

\begin{tabular}{|c|c|c|}
\hline Oudere kartering vlakken & Betekenis & Opmerking \\
\hline CODE_VEG & Vegetatietype & \\
\hline DATUM & Jaar van opname & $\begin{array}{l}\text { Eigenlijk niet van belang i.v.m. nagenoeg } \\
\text { ontbreken van overlap. }\end{array}$ \\
\hline \multicolumn{3}{|l|}{ Oudere kartering lijnen } \\
\hline CODE_VEG & Vegetatietype & \\
\hline
\end{tabular}

De verwerking van de vegetatiekartering verliep volgens de volgende stappen:

1. Lijnen

a. Elke lijn kreeg drie extra attributen die afhankelijk van het vegetatietype een waarde hebben gekregen. Het gaat om de attributen 'beheertype', 'breedte' en 'prioriteit'.

b. Met behulp van een vertaaltabel zijn de Limburgse vegetatietypen vertaald naar beheertypen.

c. De lijnen zijn gebufferd met de helft van de opgegeven breedte, waardoor een vlakelement ontstaat met de gewenste breedte. Aangezien lijnvormige vegetatietypen vlak bij elkaar kunnen liggen, kunnen de gebufferde lijnen overlap vertonen.

d. De lijnen zijn verrasterd op beheertype, rekening houdend met de opgegeven prioriteit. Cellen die (deels) overlappen met meerdere gebufferde lijnen, krijgen de waarde van de lijn met de hoogste prioriteit.

e. De verrasterde lijnen zijn een aanvulling op de L-typen van de beheertypenkaart, maar alleen op de plekken waar die nog blanco is.

2. LOCATIETYP 'vlak'

a. Elk vlak krijgt aan de hand van een vertaaltabel een beheertype toegekend op basis van het vegetatietype.

b. De vlakken worden verrasterd op beheertype.

c. De verrasterde vlakken zijn een aanvulling op de beheertypenkaart, maar alleen op de plekken waar die nog blanco is. 
De lijnvormige vegetatietypen zijn op basis van de waardes in onderstaande tabel vertaald naar beheertypen (zie Bijlage 1 voor de betekenis van de codes van de beheertypen).

\begin{tabular}{|c|c|c|c|}
\hline VegType & BT & Breedte & Prio \\
\hline$A B X$ & geen & 3 & 1 \\
\hline AGX & geen & 3 & 1 \\
\hline $\mathrm{AHX}$ & geen & 3 & 1 \\
\hline BO & $\mathrm{A} 02.01$ & 2 & 1 \\
\hline B1 & $\mathrm{N} 12.02$ & 2 & 2 \\
\hline $\mathrm{B} 1 \mathrm{G}$ & N12.02 & 2 & 9 \\
\hline $\mathrm{B} 1 \mathrm{GH}$ & L01.09 & 4 & 9 \\
\hline B1GS & N12.02 & 3 & 9 \\
\hline $\mathrm{B} 1 \mathrm{H}$ & L01.09 & 4 & 6 \\
\hline B1S & N12.02 & 3 & 7 \\
\hline B2 & N12.02 & 2 & 2 \\
\hline B2G & N12.02 & 2 & 9 \\
\hline $\mathrm{B} 2 \mathrm{GH}$ & L01.09 & 4 & 9 \\
\hline B2GS & N12.02 & 3 & 9 \\
\hline $\mathrm{B} 2 \mathrm{H}$ & L01.09 & 4 & 6 \\
\hline B2S & N12.02 & 3 & 7 \\
\hline B3 & N12.02 & 2 & 2 \\
\hline B3G & N12.02 & 2 & 9 \\
\hline B3GH & L01.09 & 4 & 9 \\
\hline B3GS & N12.02 & 2 & 9 \\
\hline B3H & L01.09 & 4 & 6 \\
\hline B3HS & L01.09 & 4 & 7 \\
\hline B3S & N12.02 & 3 & 6 \\
\hline B4 & N12.02 & 2 & 2 \\
\hline B4G & N12.02 & 2 & 9 \\
\hline B4GH & L01.09 & 4 & 9 \\
\hline B4GS & $\mathrm{N} 12.02$ & 3 & 9 \\
\hline B4H & L01.09 & 4 & 6 \\
\hline B4HS & L01.09 & 4 & 7 \\
\hline B4S & $\mathrm{N} 12.02$ & 3 & 7 \\
\hline $\mathrm{BH}$ & L01.09 & 4 & 6 \\
\hline $\mathrm{BL}$ & A13.02 & 3 & 10 \\
\hline DGO & N12.02 & 3 & 12 \\
\hline DGA & $\mathrm{N} 12.03$ & 3 & 12 \\
\hline DGD & N12.02 & 3 & 12 \\
\hline DGDG & N12.02 & 3 & 12 \\
\hline DGE & N12.06 & 3 & 12 \\
\hline DGP & N12.02 & 3 & 12 \\
\hline DGPG & $\mathrm{N} 12.02$ & 3 & 12 \\
\hline DGX & N12.02 & 3 & 12 \\
\hline DGXG & N12.02 & 3 & 12 \\
\hline $\mathrm{DHO}$ & L01.02 & 3 & 12 \\
\hline DHF & L01.02 & 3 & 12 \\
\hline DHFG & L01.02 & 3 & 12 \\
\hline DHS & L01.06 & 3 & 12 \\
\hline DHSG & L01.02 & 3 & 12 \\
\hline $\mathrm{DHX}$ & L01.02 & 3 & 12 \\
\hline DHXG & L01.02 & 3 & 12 \\
\hline EA & N14.01 & 3 & 12 \\
\hline G0 & N12.02 & 2 & 9 \\
\hline G1 & N12.02 & 2 & 9 \\
\hline G10 & N12.03 & 2 & 9 \\
\hline G3 & N12.02 & 2 & 9 \\
\hline G4 & $\mathrm{N} 12.02$ & 2 & 9 \\
\hline
\end{tabular}

\begin{tabular}{|c|c|c|c|}
\hline VegType & BT & Breedte & Prio \\
\hline G5 & $\mathrm{N} 12.02$ & 2 & 9 \\
\hline G9 & N10.01 & 2 & 9 \\
\hline $\mathrm{HC}$ & N07.01 & 3 & 10 \\
\hline $\mathrm{HD}$ & N07.01 & 3 & 10 \\
\hline $\mathrm{HE}$ & N06.04 & 3 & 10 \\
\hline IHO & L01.02 & 2 & 7 \\
\hline IHB1 & L01.02 & 4 & 13 \\
\hline IHB2 & L01.02 & 4 & 13 \\
\hline IHB3 & L01.02 & 4 & 13 \\
\hline IHB4 & L01.02 & 4 & 13 \\
\hline IHG1 & N12.02 & 2 & 14 \\
\hline IHG2 & N12.02 & 2 & 14 \\
\hline IHG3 & N12.02 & 2 & 14 \\
\hline IHG4 & N12.02 & 2 & 14 \\
\hline IHS1 & L01.02 & 3 & 8 \\
\hline IHS2 & L01.02 & 3 & 8 \\
\hline IHS3 & L01.02 & 3 & 8 \\
\hline IHS4 & L01.02 & 3 & 8 \\
\hline KG & N10.01 & 2 & 12 \\
\hline KM & N11.01 & 2 & 12 \\
\hline KZD & $\mathrm{N} 11.01$ & 2 & 12 \\
\hline LAO & N16.01 & 3 & 11 \\
\hline LAQ & N15.02 & 3 & 11 \\
\hline LAX & N15.02 & 3 & 11 \\
\hline LBX & N15.02 & 3 & 11 \\
\hline LNQR & N16.01 & 3 & 11 \\
\hline MV & N05.01 & 3 & 12 \\
\hline NO & N16.01 & 3 & 8 \\
\hline NQR & N16.01 & 3 & 8 \\
\hline NX & N16.01 & 3 & 2 \\
\hline O1W0 & L01.15 & 1 & 11 \\
\hline O1W1 & L01.15 & 1 & 11 \\
\hline O1W2 & L01.15 & 1 & 11 \\
\hline O1W3 & L01.15 & 1 & 11 \\
\hline O2W0 & L01.15 & 1 & 11 \\
\hline O2W0` & L01.15 & 1 & 11 \\
\hline $\mathrm{O} 2 \mathrm{~W} 1$ & L01.15 & 1 & 11 \\
\hline $\mathrm{O} 2 \mathrm{~W} 2$ & L01.15 & 1 & 11 \\
\hline $\mathrm{O} 2 \mathrm{~W} 2 \mathrm{H}$ & L01.15 & 2 & 11 \\
\hline $\mathrm{O} 2 \mathrm{~W} 3$ & L01.15 & 1 & 11 \\
\hline O3W0 & L01.15 & 1 & 11 \\
\hline O3W1 & L01.15 & 1 & 11 \\
\hline O3W2 & L01.15 & 1 & 11 \\
\hline O3W3 & L01.15 & 1 & 11 \\
\hline O4W0 & L01.15 & 1 & 11 \\
\hline $\mathrm{O} 4 \mathrm{WOH}$ & L01.15 & 2 & 11 \\
\hline O4W1 & L01.15 & 1 & 11 \\
\hline O4W2 & L01.15 & 1 & 11 \\
\hline O4W3 & L01.15 & 1 & 11 \\
\hline O4W4 & L01.15 & 1 & 11 \\
\hline PGO & N16.02 & 3 & 12 \\
\hline$P G X$ & N16.02 & 3 & 12 \\
\hline QR & $\mathrm{N} 15.02$ & 3 & 12 \\
\hline RA & N12.06 & 3 & 12 \\
\hline
\end{tabular}




\begin{tabular}{lllr}
\hline & & & \\
VegType & BT & Breedte & Prio \\
RC & N02.01 & 3 & 12 \\
\hline RF & N05.01 & 3 & 12 \\
\hline RH & N02.01 & 3 & 12 \\
\hline RT & N12.06 & 3 & 12 \\
\hline SD & N14.03 & 3 & 12 \\
\hline SR & N12.06 & 3 & 12 \\
\hline SS & N14.01 & 3 & 12 \\
\hline SX & N05.01 & 3 & 12 \\
\hline VA & N06.05 & 3 & 15 \\
\hline VZ & N06.06 & 3 & 15 \\
\hline X0 & geen & 2 & 2 \\
\hline XB0 & L01.02 & 3 & 15 \\
\hline XB1 & L01.02 & 3 & 15 \\
\hline XB2 & L01.02 & 3 & 15 \\
\hline XB3 & L01.02 & 3 & 15 \\
\hline XB4 & L01.02 & 3 & 15 \\
\hline XG0 & A02.01 & 3 & 15 \\
\hline XG1 & N12.02 & 3 & 15 \\
\hline XG2 & N12.02 & 3 & 15 \\
\hline XG3 & N12.02 & 3 & 15 \\
\hline XG4 & N12.02 & 3 & 15 \\
\hline & & & \\
\hline
\end{tabular}

\begin{tabular}{llll} 
VegType & BT & Breedte & Prio \\
XS1 & L01.06 & 3 & 15 \\
\hline XS2 & L01.06 & 3 & 15 \\
\hline XS3 & L01.06 & 3 & 15 \\
\hline XS4 & L01.06 & 3 & 15 \\
\hline Y3 & L01.02 & 4 & 4 \\
\hline YA1 & L01.02 & 4 & 4 \\
\hline YA2 & L01.02 & 4 & 4 \\
\hline YA3 & L01.02 & 4 & 4 \\
\hline YF1 & L01.02 & 4 & 4 \\
\hline YF2 & L01.02 & 4 & 4 \\
\hline YF3 & L01.02 & 4 & 4 \\
\hline YQ1 & L01.02 & 4 & 4 \\
\hline YQ2 & L01.02 & 4 & 4 \\
\hline YQ3 & L01.02 & 4 & 4 \\
\hline YS2 & L01.02 & 4 & 4 \\
\hline YS3 & L01.02 & 4 & 4 \\
\hline Z0 & L01.05 & 2 & 2 \\
\hline Z1 & L01.05 & 3 & 5 \\
\hline Z2 & L01.05 & 1 & 2 \\
\hline Z3 & L01.05 & 3 & 3 \\
\hline ZM & geen & 1 & 2 \\
\hline & & & \\
\hline
\end{tabular}


De vlakvormige vegetatietypen zijn op basis van de waardes in onderstaande tabel vertaald naar beheertypen.

\begin{tabular}{|c|c|c|c|}
\hline VegType & BT & VegType & BT \\
\hline AO & geen & ES & N05.01 \\
\hline$A B 0$ & geen & ESR & N05.01 \\
\hline$A B X$ & geen & $\mathrm{F}$ & N15.02 \\
\hline AGX & geen & $\mathrm{FA}$ & N14.01 \\
\hline $\mathrm{AHO}$ & geen & FAR & N15.02 \\
\hline $\mathrm{AHX}$ & geen & $\mathrm{FC}$ & N15.02 \\
\hline$A V X$ & geen & FCR & N15.02 \\
\hline B1 & $\mathrm{N} 12.02$ & $\mathrm{FR}$ & N15.02 \\
\hline B1G & N12.02 & $\mathrm{FS}$ & N14.01 \\
\hline $\mathrm{B} 1 \mathrm{GH}$ & L01.13 & FSR & N14.01 \\
\hline $\mathrm{B} 1 \mathrm{H}$ & L01.13 & G0 & N12.02 \\
\hline B2 & N12.02 & $\mathrm{G} 1$ & $\mathrm{~N} 12.02$ \\
\hline B2G & N12.02 & G10 & N12.03 \\
\hline $\mathrm{B} 2 \mathrm{GH}$ & L01.13 & G11 & N11.01 \\
\hline $\mathrm{B} 2 \mathrm{H}$ & L01.13 & G12 & N11.01 \\
\hline $\mathrm{B} 2 \mathrm{HS}$ & L01.13 & G13 & N11.01 \\
\hline B2S & $\mathrm{N} 12.02$ & G14 & N11.01 \\
\hline B3 & $\mathrm{N} 12.02$ & $\mathrm{G} 2$ & $\mathrm{~N} 12.02$ \\
\hline B3G & N12.02 & G3 & $\mathrm{N} 12.02$ \\
\hline B3GH & L01.13 & G3B & N12.02 \\
\hline B3GS & L01.13 & G4 & N12.02 \\
\hline B3H & L01.13 & G5 & N12.02 \\
\hline B3HS & L01.13 & G6 & N10.02 \\
\hline B3S & L01.13 & G7 & N10.01 \\
\hline B4 & N12.02 & G8 & N10.02 \\
\hline B4G & N12.02 & G9 & N10.01 \\
\hline $\mathrm{B} 4 \mathrm{GH}$ & L01.13 & $\mathrm{HC}$ & N07.01 \\
\hline B4H & L01.13 & $\mathrm{HCB}$ & N07.01 \\
\hline B4HS & L01.13 & $\mathrm{HCR}$ & N07.01 \\
\hline $\mathrm{BH}$ & L01.09 & $\mathrm{HCS}$ & N07.01 \\
\hline$B L$ & A13.02 & $\mathrm{HD}$ & N07.01 \\
\hline DGO & N12.02 & $\mathrm{HDB}$ & N07.01 \\
\hline DGA & $\mathrm{N} 12.03$ & HDS & N07.01 \\
\hline DGAG & $\mathrm{N} 12.02$ & $\mathrm{HE}$ & N06.04 \\
\hline DGD & N12.02 & HEB & N06.04 \\
\hline DGDG & N12.02 & $\mathrm{HM}$ & N06.04 \\
\hline DGP & $\mathrm{N} 12.02$ & HMB & N07.01 \\
\hline DGPG & N12.02 & HMS & N06.04 \\
\hline DGX & N12.02 & IHB1 & L01.02 \\
\hline DGXG & $\mathrm{N} 12.02$ & IHB2 & L01.02 \\
\hline $\mathrm{DHO}$ & L01.02 & IHB3 & L01.02 \\
\hline DHOG & L01.02 & IHB4 & L01.02 \\
\hline DHF & L01.02 & IHG1 & $\mathrm{N} 12.02$ \\
\hline DHFG & L01.02 & IHG2 & $\mathrm{N} 12.02$ \\
\hline DHS & L01.06 & IHG3 & $\mathrm{N} 12.02$ \\
\hline DHSG & L01.02 & IHG4 & $\mathrm{N} 12.02$ \\
\hline $\mathrm{DHX}$ & L01.02 & IHS1 & L01.02 \\
\hline DHXG & L01.02 & IHS2 & L01.02 \\
\hline$E$ & $\mathrm{~N} 14.03$ & IHS3 & L01.02 \\
\hline EA & N14.01 & IHS4 & L01.02 \\
\hline EAR & N14.01 & KG & N10.01 \\
\hline EB & N05.01 & $\mathrm{KK}$ & N10.01 \\
\hline EBR & N05.01 & $\mathrm{KM}$ & $\mathrm{N} 11.01$ \\
\hline ER & N14.03 & KS & N07.02 \\
\hline
\end{tabular}




\begin{tabular}{|c|c|c|c|}
\hline VegType & BT & VegType & BT \\
\hline KSB & N07.02 & O3W2 & L01.15 \\
\hline KV & N11.01 & O3W3 & L01.15 \\
\hline KZD & N11.01 & O4W0 & L01.15 \\
\hline KZN & N10.02 & O4W1 & L01.15 \\
\hline L & N15.02 & O4W2 & L01.15 \\
\hline LAO & N16.01 & O4W3 & L01.15 \\
\hline LAOR & N16.01 & OBR & L01.15 \\
\hline LAF & N15.02 & $\mathrm{P}$ & N16.02 \\
\hline LAFR & N15.02 & PAD & N16.02 \\
\hline LAQ & N15.02 & $\mathrm{PB}$ & N16.02 \\
\hline LAQR & N15.02 & PBO & N16.02 \\
\hline LAR & N15.02 & PBR & $\mathrm{N} 16.02$ \\
\hline LAX & N15.02 & $\mathrm{PE}$ & N16.02 \\
\hline LAXR & N15.02 & PER & N16.02 \\
\hline LB & N15.02 & PF & $\mathrm{N} 16.02$ \\
\hline LBO & N15.02 & PFR & N16.02 \\
\hline LBB & N15.02 & PG & N16.02 \\
\hline LBF & N15.02 & PG0 & $\mathrm{N} 16.02$ \\
\hline LBFR & N15.02 & PGX & N16.02 \\
\hline LBQ & N15.02 & PGXR & N16.02 \\
\hline LBQR & N15.02 & $\mathrm{PM}$ & $\mathrm{N} 16.02$ \\
\hline LBX & N15.02 & PMO & N16.02 \\
\hline LBXR & N15.02 & PMR & N16.02 \\
\hline LN & N16.01 & PUO & $\mathrm{N} 16.02$ \\
\hline LNO & N16.01 & PUX & N16.02 \\
\hline LNQ & N16.01 & $\mathrm{Q}$ & N15.02 \\
\hline LNQR & N16.01 & QB & N15.02 \\
\hline LNQV & N16.01 & QBR & N15.02 \\
\hline LNR & N16.01 & QF & N15.02 \\
\hline LNX & N16.01 & QFR & N15.02 \\
\hline LP & N16.01 & $\mathrm{QR}$ & N15.02 \\
\hline MK & N05.01 & $\mathrm{QR} / \mathrm{PRU}$ & N15.02 \\
\hline MKS & N05.01 & QRP & N15.02 \\
\hline MM & N05.01 & $\mathrm{QV}$ & N15.02 \\
\hline MV & N05.01 & QVR & N15.02 \\
\hline MVR & N05.01 & $\mathrm{R} 411 \mathrm{a} / \mathrm{r} 1+$ & N12.06 \\
\hline MVS & N05.01 & RA & N12.06 \\
\hline$N$ & N16.01 & $\mathrm{RC}$ & N02.01 \\
\hline No & N16.01 & RF & N05.01 \\
\hline NOR & N16.01 & RFR & N05.01 \\
\hline NQ & N16.01 & $\mathrm{RH}$ & N02.01 \\
\hline NQB & N16.01 & $\mathrm{RT}$ & N12.06 \\
\hline NQR & N16.01 & SB & N07.01 \\
\hline NQV & N16.01 & $\mathrm{SC}$ & $\mathrm{N} 14.03$ \\
\hline NQVR & N16.01 & SD & $\mathrm{N} 14.03$ \\
\hline NVT & N16.01 & SJ & N07.01 \\
\hline$N X$ & N16.01 & SR & N12.06 \\
\hline NXR & N16.01 & SS & $\mathrm{N} 14.01$ \\
\hline O1W0 & L01.15 & SSR & $\mathrm{N} 14.01$ \\
\hline O1W1 & L01.15 & SV & $\mathrm{N} 14.02$ \\
\hline O1W2 & L01.15 & SVR & $\mathrm{N} 14.02$ \\
\hline O1W3 & L01.15 & SX & N05.01 \\
\hline O2Wo & L01.15 & SXR & N05.01 \\
\hline O2W1 & L01.15 & VA & N06.05 \\
\hline $\mathrm{O} 2 \mathrm{~W} 2$ & L01.15 & VG & N06.03 \\
\hline O2W3 & L01.15 & VP & N06.06 \\
\hline o3wo & L01.15 & VS & N06.03 \\
\hline O3W1 & L01.15 & VSB & N06.03 \\
\hline
\end{tabular}




\begin{tabular}{ll} 
VegType & BT \\
VZ & N06.06 \\
\hline X0 & geen \\
\hline$X B 0$ & geen \\
\hline$X B 1$ & $L 01.02$ \\
\hline$X B 2$ & $L 01.02$ \\
\hline$X B 3$ & $L 01.02$ \\
\hline$X B 4$ & $L 01.02$ \\
\hline$X G 1$ & $N 12.02$ \\
\hline$X G 2$ & $N 12.02$ \\
\hline$X G 2 S$ & $N 12.02$ \\
\hline$X G 3$ & $N 12.02$ \\
\hline$X G 4$ & $N 12.02$ \\
\hline$X S 1$ & $L 01.06$ \\
\hline$X S 2$ & $L 01.06$ \\
\hline$X S 3$ & $L 01.06$ \\
\hline$X S 4$ & $L 01.06$ \\
\hline$Y 3$ & $L 01.02$ \\
\hline
\end{tabular}

\begin{tabular}{ll} 
VegTYpe & BT \\
YA1 & L01.02 \\
\hline YA2 & L01.02 \\
\hline YA3 & L01.02 \\
\hline YF1 & L01.02 \\
\hline YF2 & L01.02 \\
\hline YF3 & L01.02 \\
\hline YQ1 & L01.02 \\
\hline YQ2 & L01.02 \\
\hline YQ2G & L01.02 \\
\hline YQ3 & L01.02 \\
\hline YQ3G & L01.02 \\
\hline YS2 & L01.02 \\
\hline YS3 & L01.02 \\
\hline Z1 & L01.05 \\
\hline Z2 & L01.05 \\
\hline Z3 & L01.05 \\
\hline ZM & geen \\
\hline
\end{tabular}

\section{Bomenrijen, heggen en bos}

Uit Top10NL (versie november 2017) is een aantal typen rechtstreeks vertaald naar een beheertype volgens onderstaande tabel.

\begin{tabular}{ll} 
Top 10NL & Beheertype \\
Bos: loofbos & $\mathrm{N} 15.02$ \\
\hline Bos: naaldbos & $\mathrm{N} 16.01$ \\
\hline Bos: gemengd bos & $\mathrm{N} 15.02$ \\
\hline Populieren & $\mathrm{N} 16.02$ \\
\hline Griend & $\mathrm{L} 01.12$ \\
\hline Boomgaard & $\mathrm{L} 01.09$ \\
\hline Bomenrij & $\mathrm{L} 01.13$ \\
\hline Heg, haag & $\mathrm{L} 01.06$ \\
\hline
\end{tabular}

De verrasterde bomenrijen en heggen hebben rondom een extra cel $(2,5 \mathrm{~m})$ toegekend gekregen om ze een breedte te geven die meer in lijn ligt met de werkelijkheid.

\section{Boombasis}

Uit het Boombasis-bestand zijn in eerste instantie de boomkronen geselecteerd die geen intersectie vertonen met bos, bomenrijen of heggen en hagen uit Top10NL. Uit deze selectie zijn de boomkronen verwijderd die raken aan boomkronen die wel een intersectie vertonen met bos, bomenrijen of heggen en hagen uit Top10NL.

Bovenstaande werkwijze volgend, is het mogelijk dat boomkronen uit Boombasis op de overgang van bomenrij naar bomengroep zijn toegekend aan een bestaande bomenrij en dus niet zijn meegenomen. Dit is minder een probleem dan boomkronen die geen intersectie vertonen met een lijn- of vlakvormige representatie van die bomenrij, maar er duidelijk wel toe behoren, te labelen als 'vrijstaande boom of bomengroep'.

De boomkronen die overbleven zijn verrasterd met een resolutie van 2,5m en gecodeerd op basis van de waarde van het attribuut 'Klasse'. Deze waarde is op grond van de ligging binnen of buiten kernen met 1000 inwoners of meer uitgebreid met een 0 (buiten kern) of een 1 (in kern). Voor bomen, bomenrijen en bos binnen kernen is een aparte beheertypecode aangemaakt. 


\begin{tabular}{lll} 
Klasse & Beheertype & Omschrijving \\
\hline 10 & L01.13 & Bomenrij en solitaire boom buiten kern \\
\hline 20 & L01.13 & Bomenrij en solitaire boom buiten kern \\
\hline 30 & $\mathrm{~N} 15.02$ & Dennen-, eiken-, en beukenbos buiten kern \\
\hline 21 & $\mathrm{~S} 01.13$ & Bomenrij en solitaire boom in kern \\
\hline 31 & $\mathrm{~S} 01.13$ & Bomenrij en solitaire boom in kern \\
\hline
\end{tabular}

\section{Natuurrealisatie}

Voor het opnemen van de door Rijkswaterstaat en de waterschappen gerealiseerde natuurrealisatie zijn de door de provincie aangeleverde bestanden gebruikt. Daarin zaten vlakken waarin de watergangen zelf nog aanwezig waren. Vlakvormig water in Top10NL is gebruikt om de netto oppervlakte land over te houden, waaraan vervolgens het beheertype 'N12.02 Kruiden- en faunarijk grasland' is toegekend. Dit bestand is verrasterd met een resolutie van $2,5 \mathrm{~m}$ en toegevoegd aan de beheertypenkaart.

Alle water dat lijnvormig in Top10NL is opgenomen, is niet uitgespaard uit het natuurrealisatiebestand. Hiervoor zou een aantal extra handelingen nodig zijn geweest. Daarnaast bleek dat dit lijnvormige water niet altijd in de beheertypenkaart is uitgespaard en het zou de vergelijking met de analyses die op het uitgangsbestand zijn gemaakt moeilijker maken. 

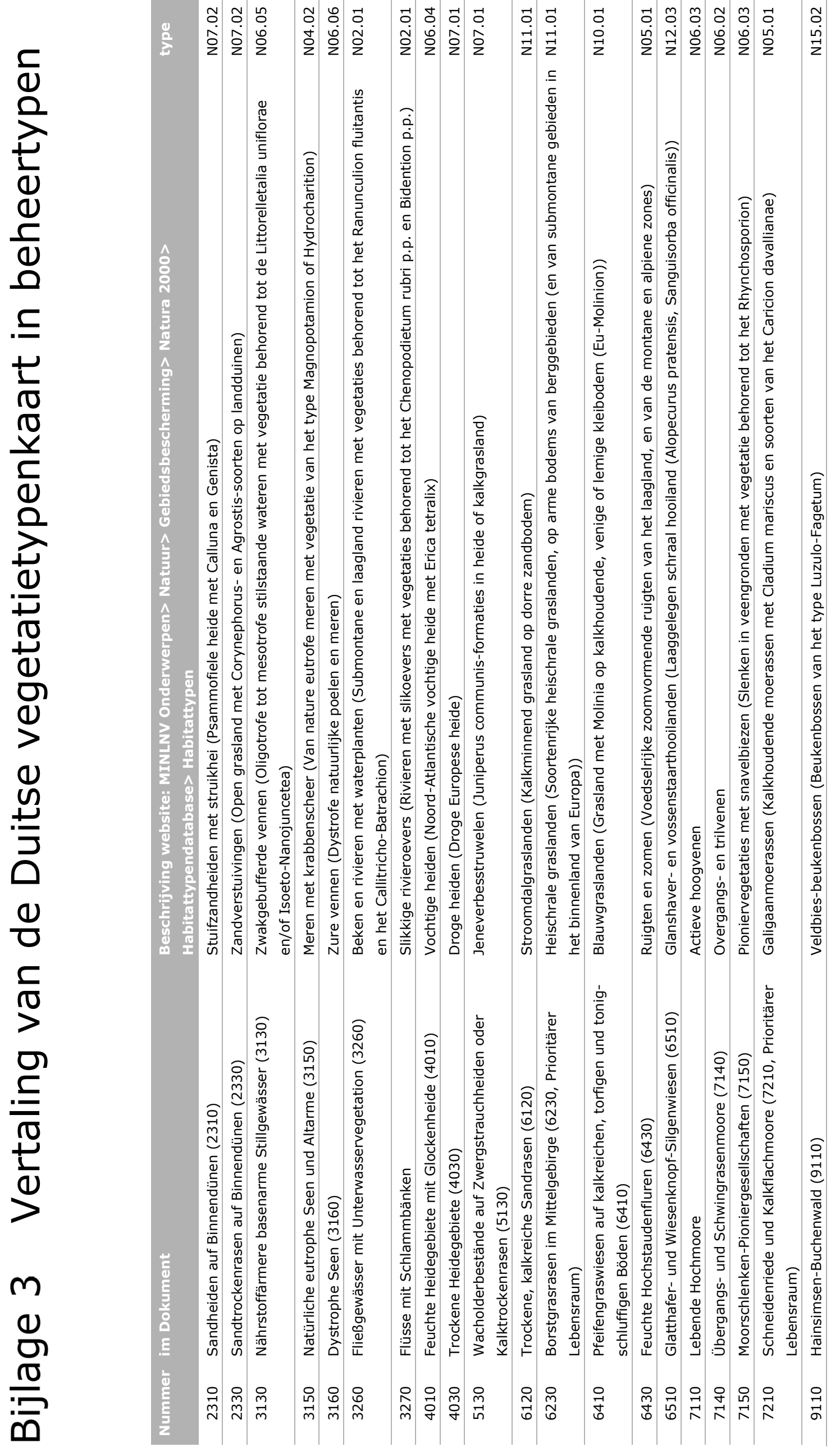


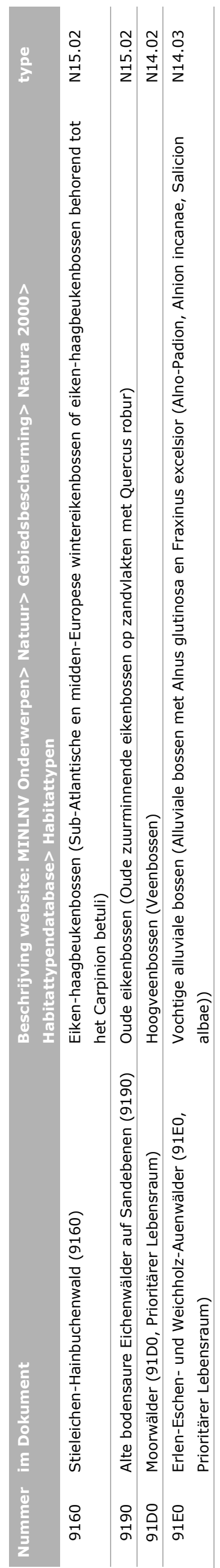

44 | Wageningen Environmental Research Rapport 2912 


\section{Bijlage 4 Vertaling van Vlaamse vegetatietypen in beheertypen}

Deze lijst is gebaseerd op de habitattypen, met extra onderverdeling. Bij de toewijzing is er rekening mee gehouden dat voor dit onderzoek alleen een strook rond Limburg vertaald hoefde te worden. De lijst is dus niet compleet en kustvegetaties zijn niet vertaald in bijbehorende kusttypen maar binnenlandse typen. De (legenda van de) Vlaamse kaart heeft als code

'BwkHab_Hab1_lijst1_hab1_omschr'.

\begin{tabular}{|c|c|c|}
\hline HAB 1 & OMSCHR & type \\
\hline 2310 & Psammofiele heide met Calluna en Genista & N07.01 \\
\hline 2310 ,bos & $\begin{array}{l}\text { Vastgelegde duinen met kruidvegetatie ('grijze duinen'), onder aanplant of met } \\
\text { bosopslag }\end{array}$ & N15.01 \\
\hline 2330 & Open grasland met Corynephorus- en Agrostis-soorten op landduinen & N07.02 \\
\hline $2330, \mathrm{gh}$ & $\begin{array}{l}\text { Open grasland met Corynephorus- en Agrostis-soorten op landduinen of geen } \\
\text { habitattype uit de Habitatrichtlijn }\end{array}$ & N07.02 \\
\hline 2330_bu & Buntgras-verbond & N07.02 \\
\hline 2330_dw & Dwerghaver-verbond & N07.02 \\
\hline 3130 & Oligotrofe tot mesotrofe stilstaande wateren & N04.02 \\
\hline $3130, \mathrm{gh}$ & Oligotrofe tot mesotrofe stilstaande wateren of geen habitattype uit de Habitatrichtlijn & N04.02 \\
\hline 3130_aom & Oeverkruidgemeenschappen (Littorelletea) & N05.01 \\
\hline 3150 & Van nature eutrofe meren met vegetatie van het type Magnopotamion of Hydrocharition & N04.02 \\
\hline $3150, \mathrm{gh}$ & $\begin{array}{l}\text { Van nature eutrofe meren met vegetatie van het type Magnopotamion of Hydrocharition } \\
\text { of geen habitattype uit de Habitatrichtlijn }\end{array}$ & N04.02 \\
\hline 3160 & Dystrofe natuurlijke poelen en meren & N04.02 \\
\hline 3260 & $\begin{array}{l}\text { Submontane en laagland rivieren met vegetaties behorend tot het Ranunculion fluitantis } \\
\text { en het Callitricho-Batrachion }\end{array}$ & N02.01 \\
\hline 3270 & Rivieren met slikoevers met vegetaties behorend tot het Chenopodion rubri & N02.01 \\
\hline 4010 & Noord-Atlantische vochtige heide met Erica tetralix & N06.04 \\
\hline 4010,4030 & Noord-Atlantische vochtige heide met Erica tetralix of Droge Europese heide & N06.04 \\
\hline 4010 , bos & Noord-Atlantische vochtige heide met Erica tetralix, onder aanplant of met bosopslag & N06.04 \\
\hline 4010,rbbsm & $\begin{array}{l}\text { Noord-Atlantische vochtige heide met Erica tetralix of regionaal belangrijk biotoop } \\
\text { gagelstruweel }\end{array}$ & N06.04 \\
\hline 4030 & Droge Europese heide & N07.01 \\
\hline 4030 , bos & Droge Europese heide, onder aanplant of met bosopslag & N07.01 \\
\hline $4030, \mathrm{gh}$ & Droge Europese heide of geen habitattype uit de Habitatrichtlijn & N07.01 \\
\hline 5130 & Juniperus communis-formaties in heide of kalkgrasland & N07.01 \\
\hline 6120 & Kalkminnend grasland op dorre zandbodem & N11.01 \\
\hline 6210_hk & Kalkrijk grasland, exclusief duingrasland (kalkgrasland (Gentiano-Koelerietum)) & N11.01 \\
\hline 6210_sk & Kalkrijke zomen en struwelen & L01.10 \\
\hline $6230, \mathrm{gh}$ & Soortenrijk heischraal grasland of geen habitattype uit de Habitatrichtlijn & N11.01 \\
\hline 6230_ha & Soortenrijke graslanden van het struisgrasverbond & N12.02 \\
\hline 6230_hmo & Vochtig heischraal grasland & N10.02 \\
\hline 6230_hn & Droog heischraal grasland & N11.01 \\
\hline 6230_hnk & Heischraal grasland met kalkminnende soorten (Betonica-Brachypodietum) & N11.01 \\
\hline 6410_ve & Basenarme Molinion-graslanden, inclusief het Veldrustype & N10.01 \\
\hline 6430 & Voedselrijke zoomvormende ruigten & N05.01 \\
\hline $6430, \mathrm{rbbhf}$ & $\begin{array}{l}\text { Voedselrijke zoomvormende ruigten of regionaal belangrijk biotoop moerasspirearuigte } \\
\text { met graslandkenmerken }\end{array}$ & N05.01 \\
\hline 6430, rbbhf, bos & $\begin{array}{l}\text { Voedselrijke zoomvormende ruigten of regionaal belangrijk biotoop moerasspirearuigte } \\
\text { met graslandkenmerken, onder aanplant of met bosopslag }\end{array}$ & N05.01 \\
\hline 6430_hf & Vochtige tot natte moerasspirearuigten & N05.01 \\
\hline 6430_hw & Verbond van harig wilgenroosje & N05.01 \\
\hline 6510 & Laaggelegen schraal hooiland: glanshaververbond & N12.03 \\
\hline
\end{tabular}




\begin{tabular}{|c|c|c|}
\hline HAB 1 & OMSCHR & type \\
\hline 6510, bos,gh & $\begin{array}{l}\text { Laaggelegen schraal hooiland: glanshaververbond, onder aanplant of met bosopslag of } \\
\text { geen habitattype uit de Habitatrichtlijn }\end{array}$ & N12.03 \\
\hline $6510, \mathrm{gh}$ & $\begin{array}{l}\text { Laaggelegen schraal hooiland: glanshaververbond of geen habitattype uit de } \\
\text { Habitatrichtlijn }\end{array}$ & N12.03 \\
\hline 6510_hu & Laaggelegen schraal hooiland: glanshaververbond; excl. onderstaande types & N12.03 \\
\hline 6510_hu,bos & $\begin{array}{l}\text { Laaggelegen schraal hooiland: glanshaververbond; excl. onderstaande types, onder } \\
\text { aanplant of met bosopslag }\end{array}$ & N12.03 \\
\hline 6510_huk & Kalkrijk kamgrasland (Galio-Trifolietum) & N11.01 \\
\hline 7110 & Actief hoogveen & N06.03 \\
\hline 7140 & Overgangs- en trilveen & N06.02 \\
\hline $7140, \mathrm{rbbms}$ & $\begin{array}{l}\text { Overgangs- en trilveen of regionaal belangrijk biotoop kleine zeggenvegetaties niet } \\
\text { vervat in overgangsveen ( } 7140)\end{array}$ & N06.02 \\
\hline 7140_meso & Basenarm tot matig basenrijk, zuur tot circum-neutraal laagveen & N06.02 \\
\hline 7140_oli & Natte heide en venoevers met hoogveensoorten & N06.06 \\
\hline 7150 & Slenken in veengronden met vegetatie behorend tot het Rhynchosporion & N06.03 \\
\hline 9110 & Beukenbossen van het type Luzulo-Fagetum & N15.02 \\
\hline 9120 & Atlantische zuurminnende beukenbossen met Ilex en soms ook Taxus in de ondergroei & N15.02 \\
\hline $9120, \mathrm{gh}$ & $\begin{array}{l}\text { Atlantische zuurminnende beukenbossen met Ilex en soms ook Taxus in de ondergroei } \\
\text { of geen habitattype uit de Habitatrichtlijn }\end{array}$ & N15.02 \\
\hline 9120_qb & Eikenberkenbos als successiestadium van de zure eiken- en beukenbossen & N15.02 \\
\hline 9120_qb,gh & $\begin{array}{l}\text { Eikenberkenbos als successiestadium van de zure eiken- en beukenbossen of geen } \\
\text { habitattype van de Habitatrichtlijn }\end{array}$ & N15.02 \\
\hline 9130_fm & $\begin{array}{l}\text { Beukenbossen van het type Asperulo-Fagetum, subtype Midden-Europees neutrofiel } \\
\text { beukenbos }\end{array}$ & N15.02 \\
\hline 9150 & Midden-Europese kalkrijke beukenbossen behorende tot het Cephalanthero-Fagion & N15.02 \\
\hline 9160 & Sub-Atlantische en midden-Europese wintereikenbossen of eikenhaagbeukbossen & N15.02 \\
\hline 9190 & Oude zuurminnende eikenbossen op zandvlakten met Quercus robur & N15.02 \\
\hline $9190, \mathrm{gh}$ & $\begin{array}{l}\text { Oude zuurminnende eikenbossen op zandvlakten met Quercus robur of geen } \\
\text { habitattype uit de Habitatrichtlijn }\end{array}$ & N15.02 \\
\hline $91 \mathrm{E0}$ & $\begin{array}{l}\text { Bossen op alluviale grond met Alnion glutinosa en Fraxinus excelsior (Alno-Padion, } \\
\text { Alnion incanae, Salicion albae) }\end{array}$ & N14.03 \\
\hline $91 \mathrm{E} 0, \mathrm{gh}$ & $\begin{array}{l}\text { Bossen op alluviale grond met Alnion glutinosa en Fraxinus excelsior (Alno-Padion, } \\
\text { Alnion incanae, Salicion albae) of geen habitattype uit de Habitatrichtlijn }\end{array}$ & N14.03 \\
\hline 91E0_sf & Zachthoutooibos & N14.01 \\
\hline 91E0_va & Beekbegeleidend vogelkers-essenbos en essen-iepenbos & N14.01 \\
\hline 91E0_vc & Goudveil-essenbos & N14.03 \\
\hline 91E0_vf & Beekbegeleidend vogelkers-essenbos en essen-iepenbos & N14.01 \\
\hline 91E0_vm & Meso- tot oligotroof elzen- en berkenbroek & N14.03 \\
\hline 91E0_vn & Ruigte-elzenbos (Filipendulo-Alnetum) & N14.03 \\
\hline 91E0_vnva & $\begin{array}{l}\text { Ruigte-elzenbos (Filipendulo-Alnetum), deels beekbegeleidend vogelkers-essenbos en } \\
\text { essen-iepenbos }\end{array}$ & N14.03 \\
\hline 91E0_vnvm & $\begin{array}{l}\text { Ruigte-elzenbos (Filipendulo-Alnetum), deels meso- tot oligotroof elzen- en } \\
\text { berkenbroek }\end{array}$ & N14.03 \\
\hline 91E0_vo & Meso- tot oligotroof elzen- en berkenbroek & N14.03 \\
\hline $91 \mathrm{F0}$ & $\begin{array}{l}\text { Gemengde oeverformaties met Quercus robur, Ulmus laevis en Ulmus minor, Fraxinus } \\
\text { excelsior of Fraxinus angustifolia, langs de grote rivieren (UImenion minoris) }\end{array}$ & N14.01 \\
\hline gh & geen habitattype uit de Habitatrichtlijn & geen \\
\hline gh, 3150 & $\begin{array}{l}\text { geen habitattype uit de Habitatrichtlijn of van nature eutrofe meren met vegetatie van } \\
\text { het type Magnopotamion of Hydrocharition }\end{array}$ & N04.02 \\
\hline rbbhc & regionaal belangrijk biotoop dotterbloemgrasland & N10.01 \\
\hline rbbhc, bos & regionaal belangrijk biotoop dotterbloemgrasland, onder aanplant of met bosopslag & N10.01 \\
\hline rbbhf & regionaal belangrijk biotoop moerasspirearuigte met graslandkenmerken & N05.01 \\
\hline rbbhf, bos & $\begin{array}{l}\text { regionaal belangrijk biotoop moerasspirearuigte met graslandkenmerken, onder } \\
\text { aanplant of met bosopslag }\end{array}$ & N05.01 \\
\hline rbbkam & soortenrijk kamgrasgrasland & N12.02 \\
\hline rbbmc & regionaal belangrijk biotoop grote zeggenvegetaties & N05.01 \\
\hline rbbmc, bos & regionaal belangrijk biotoop grote zeggenvegetaties, onder aanplant of met bosopslag & N05.01 \\
\hline rbbmr & regionaal belangrijk biotoop rietland en andere Phragmition-vegetaties & N05.01 \\
\hline
\end{tabular}




\begin{tabular}{lll} 
HAB1 & OMSCHR \\
rbbmr,bos & $\begin{array}{l}\text { regionaal belangrijk biotoop rietland en andere Phragmition-vegetaties, onder aanplant } \\
\text { of met bosopslag }\end{array}$ & N05.01 \\
\hline rbbms & $\begin{array}{l}\text { regionaal belangrijk biotoop kleine zeggenvegetaties (BWK ms) niet vervat in } \\
\text { overgangsveen (7140) }\end{array}$ \\
\hline rbbsf & regionaal belangrijk biotoop moerasbos van breedbladige wilgen \\
\hline rbbsg & brem- en gaspeldoornstruwelen & N06.06 \\
\hline rbbsm & regionaal belangrijk biotoop gagelstruweel, niet vervat in habitattypen t.g.v. hun \\
\hline rbbsm,bos & regionaal belangrijk biotoop gagelstruweel, niet vervat in habitattypen t.g.v. hun \\
\hline ondergroei, onder aanplant of met bosopslag & regionaal belangrijk biotoop vochtig wilgenstruweel op venige en zure grond \\
\hline rbbso & regionaal belangrijk biotoop doornstruwelen van leemhoudende gronden & N07.01 \\
\hline rbbzil & regionaal belangrijk biotoop zilverschoongrasland zonder zilte elementen & N07.01 \\
\hline$x$ & geen beslissing over al dan niet habitattype of regionaal belangrijk biotoop & N05.01 \\
\hline
\end{tabular}




\section{Bijlage 5 Vertaling van de vegetatietypen in Wallonië}

\begin{tabular}{lll}
\hline ET_CODE_02 & DESC_UG_NL & Ww \\
BE 2 & prioritaire open milieus & N11.01 \\
\hline BE 3 & weiden als habitat voor soorten & N11.01 \\
\hline BE 4 & uitbreidingsstroken & niet opnemen \\
\hline BE 5 & verbindingsweiden & N12.02 \\
\hline BE 6 & prioritaire bossen & N14.03 \\
\hline BE 7 & alluviale prioritaire bossen & $\mathrm{N} 14.01$ \\
\hline BE 8 & inheemse bossen van groot biologisch belang & $\mathrm{N} 14.03$ \\
\hline BE 9 & bossen als habitat voor soorten & $\mathrm{N} 15.02$ \\
\hline BE 10 & niet-inheemse verbindingsbossen & $\mathrm{N} 16.01$ \\
\hline BE 11 & kweekgronden en antropogene elementen & niet opnemen \\
\hline BE Tijd. 1 & zone onder beschermd statuut & $\mathrm{N} 11.01$ \\
\hline BE Tijd. 2 & zone voor openbaar beheer & $\mathrm{N} 15.02$ \\
\hline BE Tijd. 3 & inheemse bossen met tijdelijk statuut & $\mathrm{N} 15.02$ \\
\hline BE 1 & watermilieus & N04.02 \\
\hline
\end{tabular}




\section{Bijlage 6 Vertaling van de CORINE-typen naar beheertypen}

\begin{tabular}{|c|c|c|}
\hline CLC_CODE & OMSCHR & BT-type \\
\hline 111 & Continuous urban fabric & geen \\
\hline 112 & Discontinuous urban fabric & geen \\
\hline 121 & Industrial or commercial units & geen \\
\hline 122 & Road and rail networks and associated land & geen \\
\hline 123 & Port areas & geen \\
\hline 124 & Airports & geen \\
\hline 131 & Mineral extraction sites & geen \\
\hline 132 & Dump sites & L03.01 \\
\hline 133 & Construction sites & geen \\
\hline 141 & Green urban areas & geen \\
\hline 142 & Sport and leisure facilities & geen \\
\hline 211 & Non-irrigated arable land & $\mathrm{A} 01.02$ \\
\hline 222 & Fruit trees and berry plantations & L01.09 \\
\hline 231 & Pastures & $\mathrm{A} 01.01$ \\
\hline 242 & Complex cultivation patterns & A01.01 \\
\hline 243 & Land principally occupied by agriculture, with significant areas of natural vegetation & A01.01 \\
\hline 311 & Broad-leaved forest & N15.02 \\
\hline 312 & Coniferous forest & N16.01 \\
\hline 313 & Mixed forest & N15.02 \\
\hline 321 & Natural grasslands & N11.01 \\
\hline 322 & Moors and heathland & N06.04 \\
\hline 324 & Transitional woodland-shrub & N15.02 \\
\hline 331 & Beaches, dunes, sands & N07.02 \\
\hline 411 & Inland marshes & N05.01 \\
\hline 412 & Peat bogs & N06.03 \\
\hline 511 & Water courses & N02.01 \\
\hline 512 & Water bodies & N04.02 \\
\hline 521 & Coastal lagoons & geen \\
\hline
\end{tabular}




\section{Bijlage 7 Verkrijgen Ndep waarden 5*5km van EMEP-grid}

Ga naar http://webdab.emep.int/Unified_Model_Results

For the first time annual averaged model results from a status run for 2013 are available also in the new EMEP $0.1^{\circ}$ $x 0.1^{\circ}$ longitude-latitude grid. The fine scale model data can not yet be retrieved using the selection baxes below, but downloadable as a netCDf file here.

\section{Table 1: Data selection}

\begin{tabular}{|l|}
\hline Countries / Areas \\
\hline ALL \\
\hline EU15 \\
EU25 \\
EU27 \\
SHIPS \\
\hline
\end{tabular}

\begin{tabular}{|l|}
\hline Years \\
\hline 2014 emis 2013 \\
\hline 2013 \\
\hline 2012 \\
2012 v2015 \\
2011 \\
\hline
\end{tabular}

\begin{tabular}{|c|c|c|c|}
\hline \multicolumn{4}{|c|}{ Air Concentrations } \\
\hline Main Pollutants & & PMI & \\
\hline $\begin{array}{l}\mathrm{SO} 2 \\
\mathrm{SO} 4 \\
\mathrm{NO} 2\end{array}$ & $\wedge$ & $\begin{array}{l}\text { PM10 } \\
\text { PM2.5 } \\
\text { PMcoarse }\end{array}$ & $\wedge$ \\
\hline $\begin{array}{l}\mathrm{NH} 3+\mathrm{NH}_{4}+ \\
\mathrm{HNO} 3+\mathrm{NO} 3\end{array}$ & $\checkmark$ & $\begin{array}{l}\text { Primary PM10 } \\
\text { Primary PM2.5 }\end{array}$ & $\checkmark$ \\
\hline
\end{tabular}

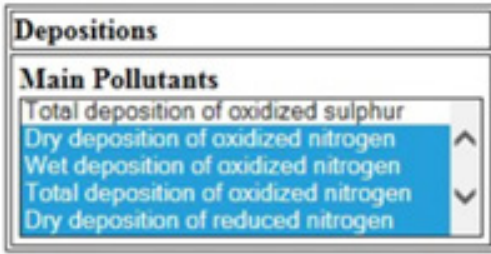

\begin{tabular}{|l|l|}
\hline Type and Format \\
\hline Grid $(50 \mathrm{~km} \times 50 \mathrm{~km})$. Semicolon-Separated \\
\hline
\end{tabular}

Klik op here aan het einde van bovenste groene tekst, dan wordt een netCDF-file "EMEP01deg_year.2013.nc" gedownload.

Dit bestand kun je inlezen in ArcGIS.

Daarna kun je met de tool "Make NetCDF RasterLayer" uit de toolbox "Multidimension Tools.tbx" selecteren welke gegevens ermee moeten worden genomen uit het bestand. Daarna kun je de gewenste layers optellen.

D:\UserData\2018\Projecten\POL_Limburg_GoudGroen\Mxd \Analyse_MNP_Limburg_Scenario2_54_Ab iot. $m x d$

D:\UserData \2018\Projecten\POL_Limburg_GoudGroen\Mxd\Analyse_MNP_EMEP_Ndep_2.mxd 


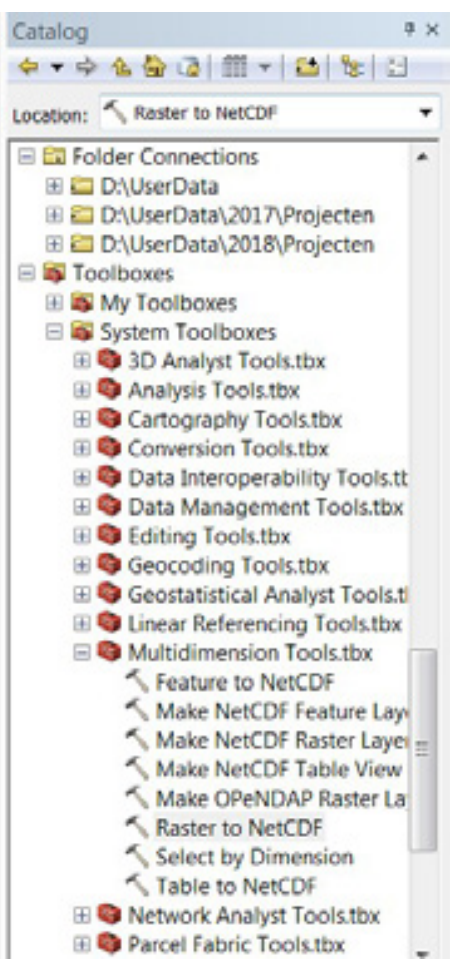

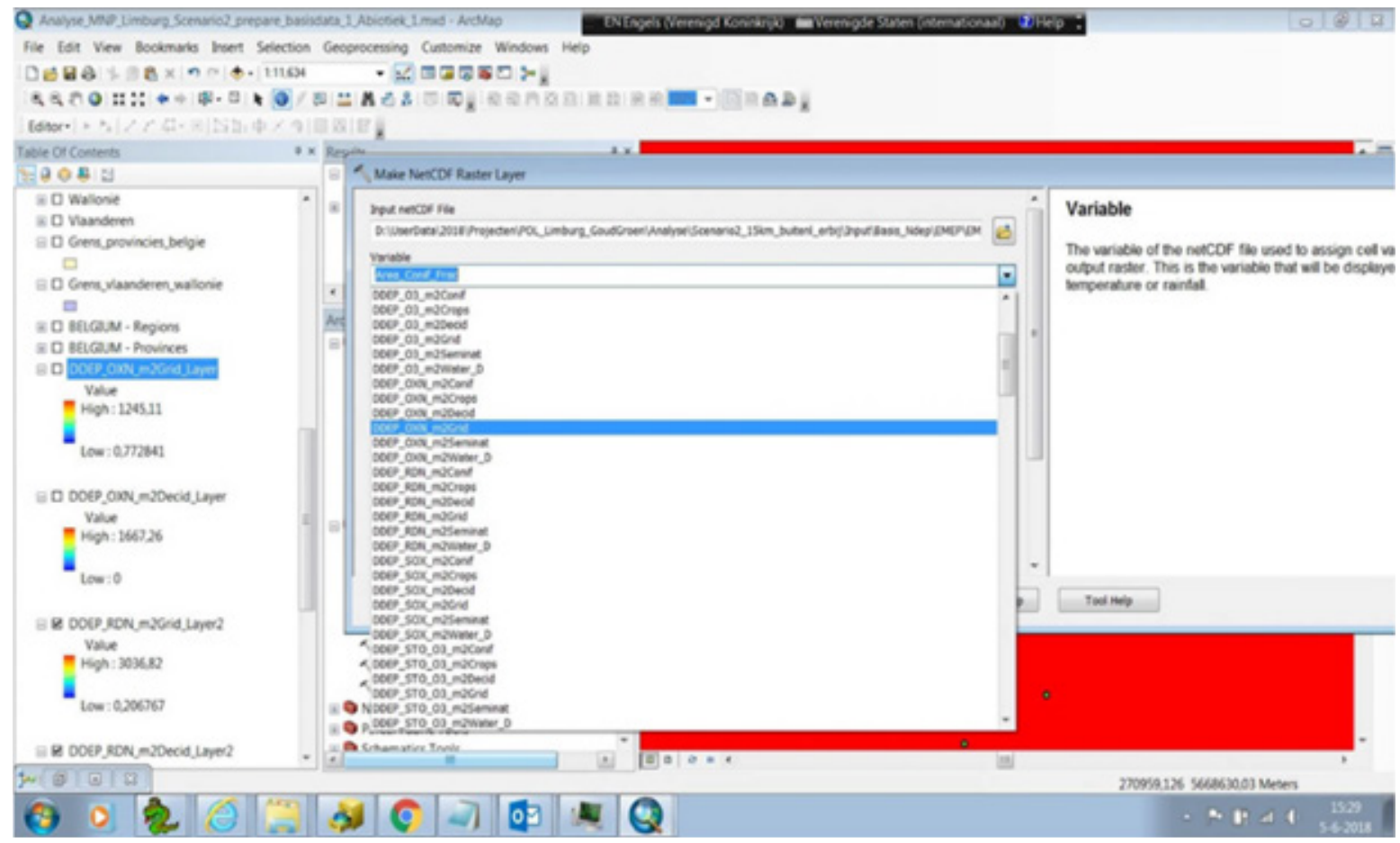

$N T O T=W D E P \_R D N+$ DDEP_RDN + DDEP_OXN

$\square \square$ EMEP_5km_NETCDF

$\boxplus \square$ ntot_rd_25m_m

$\oplus \square$ Ntot_rd_msk4

$\boxplus \square$ ntot_rd_msk

$\boxplus \square$ WDEP_RDN_rd

$\boxplus \square$ DDEP_RDN_rd

$\boxplus \square$ DDEP_OXN_rd 


\section{Bijlage 8 Vegetatietypen en abiotiek buitenland}

Alle technische stappen voor het maken van de bestanden van scenario 2 zijn te vinden in TOOLBOX

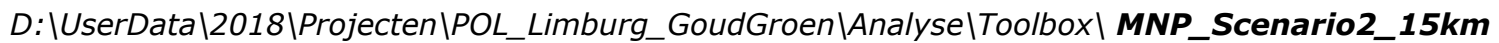

MNP_Scenario2_15km

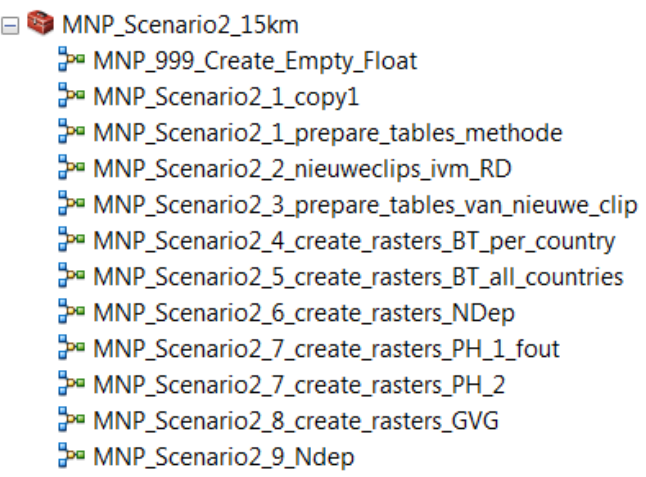

De gegevens die gebruikt zijn, zijn te vinden in de mxd's die bij de verschillende onderliggende TOOLS horen.

Voorbeeld 1:

Voor Tool MNP_Scenario2_create_rasters_BT_percountry zijn de gegevens te vinden in D:\UserData \2018\Projecten\POL_Limburg_GoudGroen\Mxd \Analyse_MNP_Limburg_Scenario2_p repare_basisdata_11_Beheertypen_combineer_alle_landen.mxd

Voorbeeld 2:

Voor Tool MNP_Scenario2_create_rasters_NDep zijn de gegevens te vinden in D:\UserData\2018\Projecten\POL_Limburg_GoudGroen\Mxd\

D: \UserData \2018\Projecten\POL_Limburg_GoudGroen \Mxd \Analyse_MNP_Limburg_Sce nario2_54_Abiot.mxd

En

D:\UserData \2018\Projecten\POL_Limburg_GoudGroen\Mxd\Analyse_MNP_EMEP_Ndep_2.mxd 


\section{Bijlage 9 Oppervlakte natuur binnen het NNN en toegevoegde natuur conform scenario 1 (toevoegen kleine landschapselementen)}

Onderstaande tabel geeft de oppervlakten volgens de kaarten. De toegevoegde oppervlakte is inclusief toevoegingen van kleine landschapselementen binnen het NNN. Die valt dus weg uit het huidige NNN en komt bij de toegevoegde typen. Strikt genomen vindt er een typeverandering plaats binnen het NNN, omdat gedetailleerdere informatie beschikbaar is (bv. lijnvormige elementen). Hierdoor valt het oppervlak NNN dus lager uit en het toegevoegde oppervlak hoger.

\begin{tabular}{|c|c|c|c|}
\hline Beheertype & Naam & $\begin{array}{r}\text { Opp. } \\
\text { binnen } \\
\text { NNN in } \\
\text { ha }\end{array}$ & $\begin{array}{r}\text { Opp. } \\
\text { buiten } \\
\text { NNN in } \\
\text { ha }\end{array}$ \\
\hline A01.01 & A01.01 Weidevogelgebied & 482 & 0 \\
\hline A01.02 & A01.02 Akkerfaunagebied & 528 & 0 \\
\hline A01.03 & A01.03 Ganzenfourageergebied & 43 & 0 \\
\hline A02.01 & A02.01 Botanisch waardevol grasland & 507 & 2 \\
\hline A02.02 & A02.02 Botanisch waardevol akkerland & 3 & 0 \\
\hline L01.01 & L01.01 Poel en kleine historische wateren & 26 & 24 \\
\hline L01.02 & L01.02 Houtwal en houtsingel & 120 & 755 \\
\hline L01.03 & L01.03 Elzensingel & 1 & 1 \\
\hline L01.05 & L01.05 Knip- of scheerheg & 15 & 39 \\
\hline L01.06 & L01.06 Struweelhaag & 9 & 377 \\
\hline L01.07 & L01.07 Laan & 1 & 2 \\
\hline L01.08 & L01.08 Knotboom & 4 & 4 \\
\hline L01.09 & L01.09 Hoogstamboomgaard & 124 & 1495 \\
\hline L01.10 & L01.10 Struweelrand & 1 & 1 \\
\hline L01.11 & L01.11 Hakhoutbosje & 0 & 0 \\
\hline L01.13 & L01.13 Bomenrij of solitaire boom & 3 & 5259 \\
\hline L01.14 & L01.14 Rietzoom en klein rietperceel & 0 & 0 \\
\hline L01.16 & L01.16 Bossingel & 50 & 50 \\
\hline N00.01 & N00.01 Nog om te vormen landbouwgrond naar natuur (inrichting) & 5263 & 1 \\
\hline N01.03 & N01.03 Rivier- en moeraslandschap & 2 & 0 \\
\hline N02.01 & N02.01 Rivier & 171 & 42 \\
\hline N03.01 & N03.01 Beek en Bron & 292 & 6 \\
\hline N04.01 & N04.01 Kranswierwater & 1 & 0 \\
\hline N04.02 & N04.02 Zoete Plas & 1165 & 0 \\
\hline N05.01 & N05.01 Moeras & 0 & 88 \\
\hline N05.01.02 & N05.01.02 Landriet & 0 & 0 \\
\hline N05.01.05 & N05.01.05 Veenmosrietland & 0 & 0 \\
\hline N05.01.06 & N05.01.06 Moerasstruweel & 0 & 0 \\
\hline N05.01.07 & N05.01.07 Moerasloofbos & 21 & 0 \\
\hline N05.01.08 & N05.01.08 Moerasnaaldbos & 0 & 0 \\
\hline N05.01.10 & N05.01.10 Hoogveenbos & 4 & 0 \\
\hline N05.01.11 & N05.01.11 Galigaanmoerassen & 0 & 0 \\
\hline N05.02 & N05.02 Gemaaid rietland & 5 & 0 \\
\hline N06.01 & N06.01 Veenmosrietland en moerasheide & 0 & 0 \\
\hline N06.03 & N06.03 Hoogveen & 243 & 0 \\
\hline N06.04 & N06.04 Vochtige heide & 1252 & 36 \\
\hline N06.05 & N06.05 Zwakgebufferd ven & 246 & 26 \\
\hline N06.06 & N06.06 Zuur ven en hoogveenven & 207 & 6 \\
\hline
\end{tabular}




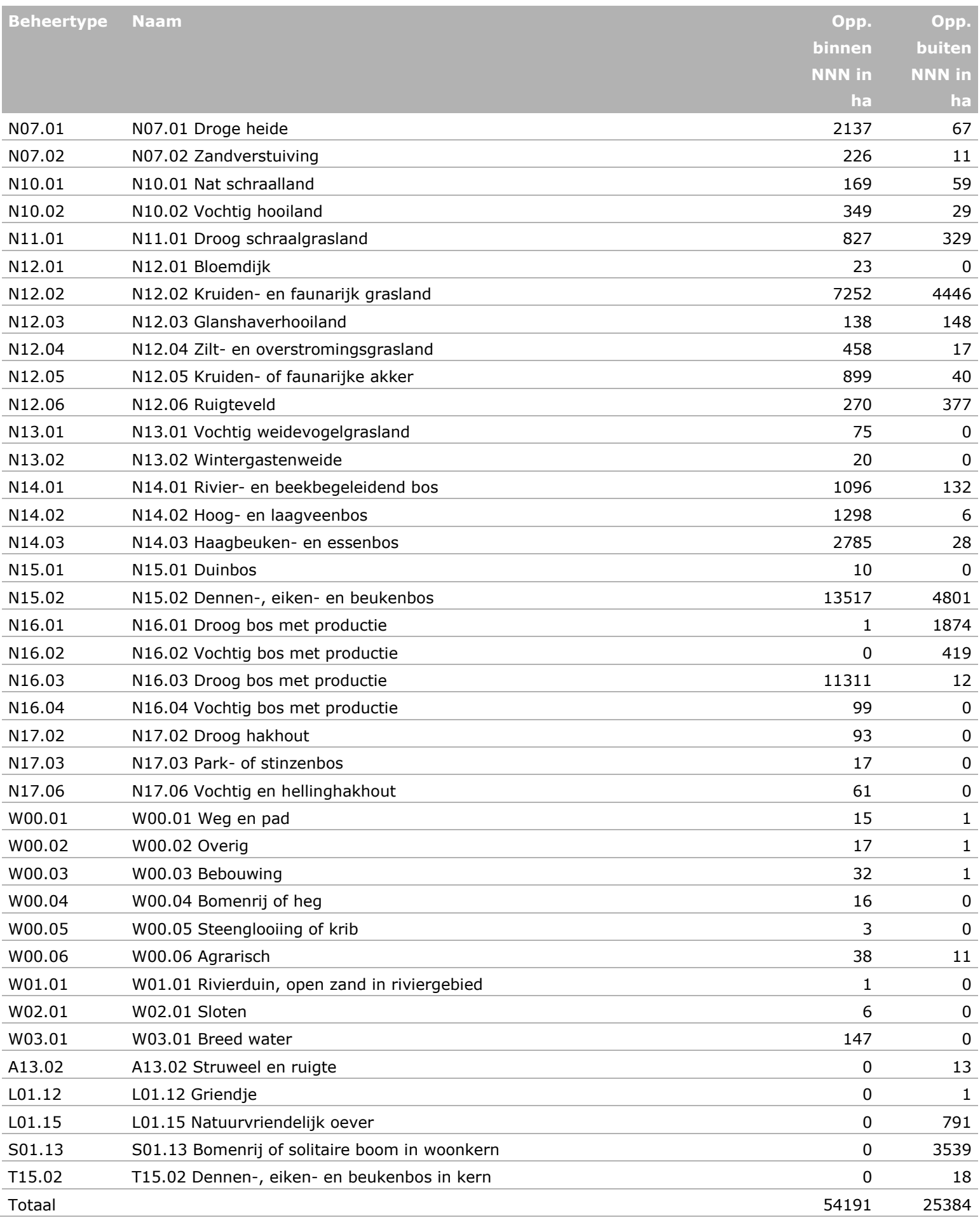




\section{Bijlage 10 Toegevoegde natuur per beheertype voor scenario 2 , het buitenland}

\begin{tabular}{|c|c|c|}
\hline Beheertype & Naam & Opp. in ha \\
\hline A01.01 & A01.01 Weidevogelgebied & 97046 \\
\hline A01.02 & A01.02 Akkerfaunagebied & 160141 \\
\hline L01.09 & L01.09 Hoogstamboomgaard & 2881 \\
\hline L01.10 & L01.10 Struweelrand & 0 \\
\hline L03.01 & L03.01 Aardwerk en groeve & 728 \\
\hline N02.01 & N02.01 Rivier & 1336 \\
\hline N04.02 & N04.02 Zoete Plas & 1461 \\
\hline N05.01 & N05.01 Moeras & 1349 \\
\hline N06.02 & N06.02 Trilveen & 50 \\
\hline N06.03 & N06.03 Hoogveen & 42 \\
\hline N06.04 & N06.04 Vochtige heide & 1710 \\
\hline N06.05 & N06.05 Zwakgebufferd ven & 7 \\
\hline N06.06 & N06.06 Zuur ven en hoogveenven & 26 \\
\hline N07.01 & N07.01 Droge heide & 1438 \\
\hline N07.02 & N07.02 Zandverstuiving & 98 \\
\hline N10.01 & N10.01 Nat schraalland & 131 \\
\hline N10.02 & N10.02 Vochtig hooiland & 0 \\
\hline N11.01 & N11.01 Droog schraalgrasland & 545 \\
\hline N12.02 & N12.02 Kruiden- en faunarijk grasland & 676 \\
\hline N12.03 & N12.03 Glanshaverhooiland & 396 \\
\hline N14.01 & N14.01 Rivier- en beekbegleidend bos & 188 \\
\hline N14.02 & N14.02 Hoog- en laagveenbos & 58 \\
\hline N14.03 & N14.03 Haagbeuken- en essenbos & 1998 \\
\hline N15.01 & N15.01 Duinbos & 4 \\
\hline N15.02 & N15.02 Dennen-, eiken- en beukenbos & 34072 \\
\hline N16.01 & N16.01 Droog bos met productie & 22341 \\
\hline Totaal & Zonder agrarisch & 71535 \\
\hline Totaal & Met agrarisch & 328721 \\
\hline
\end{tabular}




\section{Bijlage 11 Verslag bijeenkomst}

Aanwezig: W. Alblas (Limburgs-Landschap); F. Baselmans (Natuurmonumenten); G Jonkman (Staatsbosbeheer); H. Heijnen (Stichting Milieu Federatie limburg); M. Niessen (Natuurrijk Limburg); Bram Derikx (Natuurrijk Limburg); C. Salomons-Raven (provincie Limburg); P. Voskamp (provincie Limburg); T. Mulder (notities, provincie Limburg) en W. Wamelink (presentatie, Wageningen Environmental Research).

Vragen naar aanleiding van de bijeenkomst op 1-6-2018 waar de eerste resultaten van het project zijn besproken met daarachter onze reactie.

Bram Dericx / NaLi:

a) Wij (maar ook de rijks- en provinciale overheden) hebben veel interesse in / belang bij berekening van het apart doorrekenen van de effecten van het verbeteren van de milieu- en water-parameters (stikstofdepositie, ph en GVG) op de nu buiten goudgroen toegevoegde natuurwaarden.

Het is immers goed om te weten hoeveel die natuurwaarden dan opleveren qua duurzaam in stand te houden soorten en om te weten of het effectiever respectievelijk belangrijker is de $\mathrm{N}$-depositie helemaal op orde te krijgen of dat we vooral moeten werken aan de GVG resp. de pH.

Wij zijn al uitgedaagd door gedeputeerde Hubert Mackus om dat aan te geven o.b.v.

literatuuronderzoek.

Reactie W. Wamelink: Dat kan echter, dat is dan wel substantieel meerwerk. Aan de discussie zijn wel een stuk of wat zinnen toegevoegd die aangeven aan welke richting we dan zouden moeten denken.

b) Wij hebben er tevens belang bij om te weten hoe groot het positieve effect op de biodiversiteit is van verhoging van het gehalte aan organische stof in de bodem in landbouwgebieden.

Reactie W. Wamelink: Wij kunnen dat momenteel alleen doen voor de in het model opgenomen plantensoorten en alleen voor zover het gat om het effect van een verbeterde $\mathrm{C} / \mathrm{N}$-ratio in de bodem; alleen daarvan is voldoende bekend hoe de in het model gebruikte plantensoorten erop reageren. Het model zou dan wel met een extra rekenmodule uitgebreid moeten worden. Er zijn wel mogelijkheden om via berekeningen hierover iets te zeggen en op basis van literatuuronderzoek.

3. Marc Niessen:

a) Kan er ook uitgerekend worden wat het voor de biodiversiteit oplevert wanneer we zones uit de landbouw halen (en omvormen naar natuur) langs alle beken en rivieren?

Reactie W. Wamelink: Dat kan, echter ook dat is substantieel meerwerk en kan niet uitgevoerd worden in het kader van de huidige opdracht.

b) Mijn indruk is dat voor de zones rondom in B. en Dtsl. op veel ruimere schaal agrarische gebieden met akkerfauna resp. weidegebieden met weidevogels zijn toegevoegd dan in Limburg zelf.

S.v.p. dezelfde aanpak hanteren voor Limburg en aangrenzend buitenland.

Reactie W. Wamelink: Zullen we doen. Deze vraag is gelinkt aan vraag 4. Uiteindelijk is dit verzoek niet uitgevoerd, ondanks de toezegging, en is de suggestie onder 4 gevolgd. In de discussie van het rapport en materiaal en methode wordt uitgelegd waarom en wat de gevolgen hiervan zijn voor het eindresultaat.

4. Wilfred Alblas/LL:

S.v.p. discussies zoals bij de 2 e opmerking van Marc voorkomen door duidelijk te maken wat je precies gedaan hebt en waarom je dat zo gedaan hebt. Voor mij hoef je niet per se de kaarten weer aan te passen, mits je maar uitlegt waarom je binnen en buiten Limburg een iets andere benadering hebt toegepast.

Reactie W. Wamelink: Akkoord, zullen we doen. Zie ook de reactie onder vraag 3. 
5. Gerard Jonkman/SBB:

a) Er is een gerede kans dat er geconcludeerd wordt dat er - vooral doordat de gebieden in D. en B. worden meegenomen -een redelijk aantal extra soorten in de groep terechtkomt waarvoor voldaan is aan de voorwaarde voor duurzame instandhouding. Dit kan ertoe leiden dat politici gaan vragen of het dan niet een tandje minder kan met de Ontwikkelopgave. Om die discussie helder te voeren, zou ik graag zien dat door WENR wordt aangegeven voor welke soorten wel en niet aan de voorwaarden voldaan wordt c.q. per 2027 voldaan gaat worden.

Zijn het typisch Limburgse soorten?

Zijn het soorten waarvan we eigenlijk al wisten dat de duurzame instandhouding wel gegarandeerd is? Kortom: levert het echt iets op voor de biodiversiteitsscore van Limburg of is het alleen maar het corrigeren van een fout in de berekeningen tot nu toe?

Reactie W. Wamelink: De lijsten van de soorten in de 3 categorieën (duurzaam, niet duurzaam en de tussencategorie) kunnen we aanleveren, zal ik regelen. Zie ook het stuk in de discussie. In principe worden geen resultaten van individuele soorten gepubliceerd of verstrekt. De wens is begrijpelijk en logisch, maar de onzekerheid in de individuele soortresultaten is (nog) te groot om daar conclusies aan te verbinden. Voor dit project is een eenmalige uitzondering gemaakt en zijn de resultaten beschikbaar gesteld aan de provincie, zodat zij dit inzicht kunnen verkrijgen. In de discussie wordt hier wel nog per soortgroep op ingegaan. 


\section{Bijlage 12 Review}

Het rapport is gereviewd door dr. A. van Hinsbergen van het Planbureau van de Leefomgeving (PBL). Hieronder de review en de reactie daarop van de auteurs.

Review: Rapport Wamelink, G.W.W, M.H.C. van Adrichem, H.A.M. Meeuwsen, J.Y. Frissel, I. Woltjer, B. de Knegt \& R. Pouwels, 2018. Effect van kleine landschapselementen en buitenlandse natuur op het duurzaam voorkomen van soorten in de provincie Limburg. Doorrekening met het MNP. Wageningen, Wageningen Environmental Research' versie 14-09-2017.

Reviewer: A. van Hinsberg, PBL

Algemeen: Het rapport heeft als doel 'inzicht te geven wat de bijdrage van de natuur buiten de POL (NNN) gebieden in de provincie Limburg is op de duurzame instandhouding van dier- en plantpopulaties binnen de NNN'. Deze vraagstelling komt deels voort uit een studie van PBL/WUR (2017) naar evaluatie van het Natuurpact, waarin o.a. met een modelstudie is gekeken naar de invloed van natuurmaatregelen van provinciaal beleid in NNN op de nationale VHR-doelen. Gezien die achtergrond zijn de gevolgde aanpak (modelstudie), modelkeuze en indicatorkeuze voor biodiversiteitseffect (landelijk voorkomen VHR-soorten) logisch. De gehanteerde uitbreiding van effectindicatoren naar bredere biodiversiteit (waaronder Rode Lijst en soorten die daarvan in Limburg voorkomen) en aandacht voor duurzaam voorkomen binnen alleen Limburg geeft bovendien aanvullende informatie voor provinciaal niveau.

Ook de pragmatische aanpak om natuur buiten het NNN (in Limburg en daarbuiten) in beeld te brengen en aan te vullen op provinciale beheerkaarten is gezien de doorlooptijd begrijpelijk en passend bij de verkennende vraagstelling van de studie. De gepresenteerde modeluitkomsten zijn (rekening houdend met methode) ecologisch plausibel en passend bij eerdere modelstudies. De uitkomsten bieden aanknopingspunten voor beleid.

Echter op gebied van beleid t.a.v. landschapselementen en grensoverschrijdend (natuur/milieu)beleid geeft het rapport weinig aanbevelingen. Op basis van resultaten zouden bijvoorbeeld handelingsperspectieven gegeven kunnen worden over afstemming van beleidssporen (afstemming natuurbeleid stad-landelijkgebied-NNN-buitenland, beheer/inrichting/aanleg van landschapselementen, monitoring van landschapselementen etc.) [1]. Daarnaast valt op dat een aantal beleidsaanbevelingen niet direct komt uit deze studie zelf. Dit wordt ook aangegeven in de tekst, maar de rapportage zou aan beleidsbruikbaarheid en wetenschappelijke basis winnen als bij die teksten beter wordt aangegeven waar de onderbouwing vandaan komt (expertkennis, wij denken etc.). Gezien de gebruikte methode is het bovendien goed om de conclusies scherper te formuleren en rekening te houden met ingebakken beperkingen [2].

Methode en conclusies: Het gebruikte model is op nationale schaal gevalideerd/gekalibreerd voor de huidige situatie, uitgaande van alleen modelinvoer over het NNN (zonder landschapselementen buiten het NNN) met landelijke verspreidingsgegevens van soorten (zie status A rapport MNP). Bij de in de studie gebruikte soorten was er volgens experts een landelijke, voldoende goede fit tussen verspreiding en modeluitkomst, om het model te gebruiken in landelijke studies. Onduidelijk is nog hoe toevoeging van m.n. de landschapselementen buiten NNN aan de modelinvoer, en de op basis daarvan berekende grote toename in populaties, zich verhoudt tot de validatie. Zonder inzicht in invloed op validatie is het wellicht beter te spreken over potentiële betekenis van

landschapselementen. Temeer omdat bij doorrekening is aangenomen dat milieu-/watercondities in de landschapselementen optimaal/niet-belemmerend zijn voor voorkomen van de daaraan toegewezen soorten (tekst paragraaf 2.3.3) of gebaseerd zijn op kaarten van een geheel ander schaalniveau (zie paragraaf 2.3.5). Zoals ook in de discussie is aangegeven, zullen milieu-/watercondities (en wellicht beheer/inrichting) in landschapselementen in de praktijk niet zo goed zijn (gezien randlengte, ligging dichterbij bronnen van milieubeïnvloeding, directere beïnvloeding, aanvullende drukfactoren etc.). In de berekening is nu eigenlijk uitgegaan dat bij kleine elementen de randvoorwaarden beter zijn dan in natuurgebieden. In de discussie is al aangegeven dat hierdoor sprake zal zijn van een overschatting. 
De omvang van de overschatting is onduidelijk en zou achterhaald kunnen worden door te rekenen met slechte condities of goede condities in natuurgebieden. Gezien de onduidelijkheid is het juister om in conclusies aan te geven dat 'kleine landschapselementen, mits bij optimale milieukwaliteit, een grote bijdrage kunnen hebben op de potentie van ...'[3].

Vergelijking met cijfer uit Natuurbalans is onduidelijk. Percentages zijn niet helemaal een-op-een te vergelijken [4] (alle soorten versus VHR-soorten, focus op 'Limburgse' soorten, aanpassingen Limburgse beheertype kaart, verandering neerschalingsmethode). Toekomstige inschattingen van condities van doelbereik zijn worden daarnaast beïnvloed door voortgang beleid, nieuwe ontwikkelingen (bv. markerwadden), aanpassingen/nieuw beleid (klimaattafels etc.).

Technische aanbevelingen: Het rapport geeft wat aanzetten over hoe in de toekomst het modelinstrumentarium zou kunnen worden. De resultaten laten zien dat het uitmaakt naar welke effectparameters gekeken wordt (duurzaamheid in een afzonderlijke provincie of gezamenlijk landelijk; effect op natuur in termen van populatieveranderingen of duurzaamheidsveranderingen) en welke aspecten moeten worden meegenomen (natuur in buitenland beschouwen of niet, landschapselementen meenemen of niet en welke condities in beide gelden). Het rapport gaat echter niet in op consequenties (voor- en nadelen van aanpak) en bijvoorbeeld de koppeling met beleidsvragen en gegeven natuurbeleidsdoelen [5]. Modelgebruik zal altijd vragen om optimalisatie van aanpak en goed overleg daarover. Aanbevelingen over proces van werkwijzen geeft het rapport echter niet [6].

Tekstueel: De huidige conceptteksten zijn soms nog wat onduidelijk en/of rommelig. In de tekst heb ik een aantal voorstellen gedaan voor verduidelijking. Ten aanzien van aanpak is het wellicht duidelijker als bijvoorbeeld in tabel vorm per gebiedstype (NNN, landschapselement, buitenland, akker/grasland) wordt en conditie wordt aangegeven welke conditie is verondersteld [7].

Reactie auteurs

Dank voor de review. Wij hebben de tekstuele voorstellen nagenoeg geheel overgenomen. Een paar specifieke punten zijn niet overgenomen, omdat ze inhoudelijk niet helemaal correct waren.

Hieronder wordt beschreven wat we hebben gedaan met de geel gearceerde delen uit de review. Deze zijn door ons genummerd in het reviewrapport.

[1]. Aanbevelingen in deze richting zijn zeker nuttig. Maar afstemmingen tussen stad en land en buitenland m.b.t. handelingsperspectieven valt buiten de opdracht van dit project.

[2]. De ook tekstueel gedane aanbevelingen hierover zijn overgenomen.

[3]. Er zijn geen extra doorrekeningen toegevoegd om het effect van een mindere kwaliteit van de kleine landschapselementen te schatten. Dat er een effect is, zal duidelijk zijn en is ook verwoord in de discussie. Bij de conclusie in het begin van de discussie is een extra stukje toegevoegd om duidelijk te maken dat we met optimale condities hebben gewerkt en dat bij mindere kwaliteit de bijdrage ook minder is.

[4]. Het klopt dat er wat aanpassingen zijn, maar dat was ook de bedoeling van de opdracht. Een vergelijking met een eerdere uitkomst lijkt ons altijd mogelijk, maar het is wel van belang om daarbij rekening te houden met wat er is veranderd, dus inclusief een nieuwere beheertypenkaart. Maar dit staat beschreven in het rapport. De neerschalingsmethode is niet veranderd t.o.v. de landelijke doorrekening.

[5]. We gaan inderdaad niet verder in op voor- en nadelen etc. Dat ligt duidelijk buiten de scope van dit project. We snappen dat dit interessant is voor verdere ontwikkeling en toepassing van het model, maar daar dient in een ander project nader over te worden nagedacht.

[6]. Eens, maar zie punt 5, dat valt buiten dit project.

[7]. Dit lijkt inderdaad nuttig, maar per type aangeven geeft een zeer grote tabel, die te weinig extra inzicht zou geven. 
Wageningen Environmental Research Postbus 47

6700 AA Wageningen

T 0317480700

www.wur.nl/environmental-research

Wageningen Environmental Research

Rapport 2912

ISSN 1566-7197
De missie van Wageningen University \& Research is 'To explore the potential of nature to improve the quality of life'. Binnen Wageningen University \& Research bundelen Wageningen University en gespecialiseerde onderzoeksinstituten van Stichting Wageningen Research hun krachten om bij te dragen aan de oplossing van belangrijke vragen in het domein van gezonde voeding en leefomgeving. Met ongeveer 30 vestigingen, 5.000 medewerkers en 10.000 studenten behoort Wageningen University \& Research wereldwijd tot de aansprekende kennisinstellingen binnen haar domein. De integrale benadering van de vraagstukken en de samenwerking tussen verschillende disciplines vormen het hart van de unieke Wageningen aanpak. 



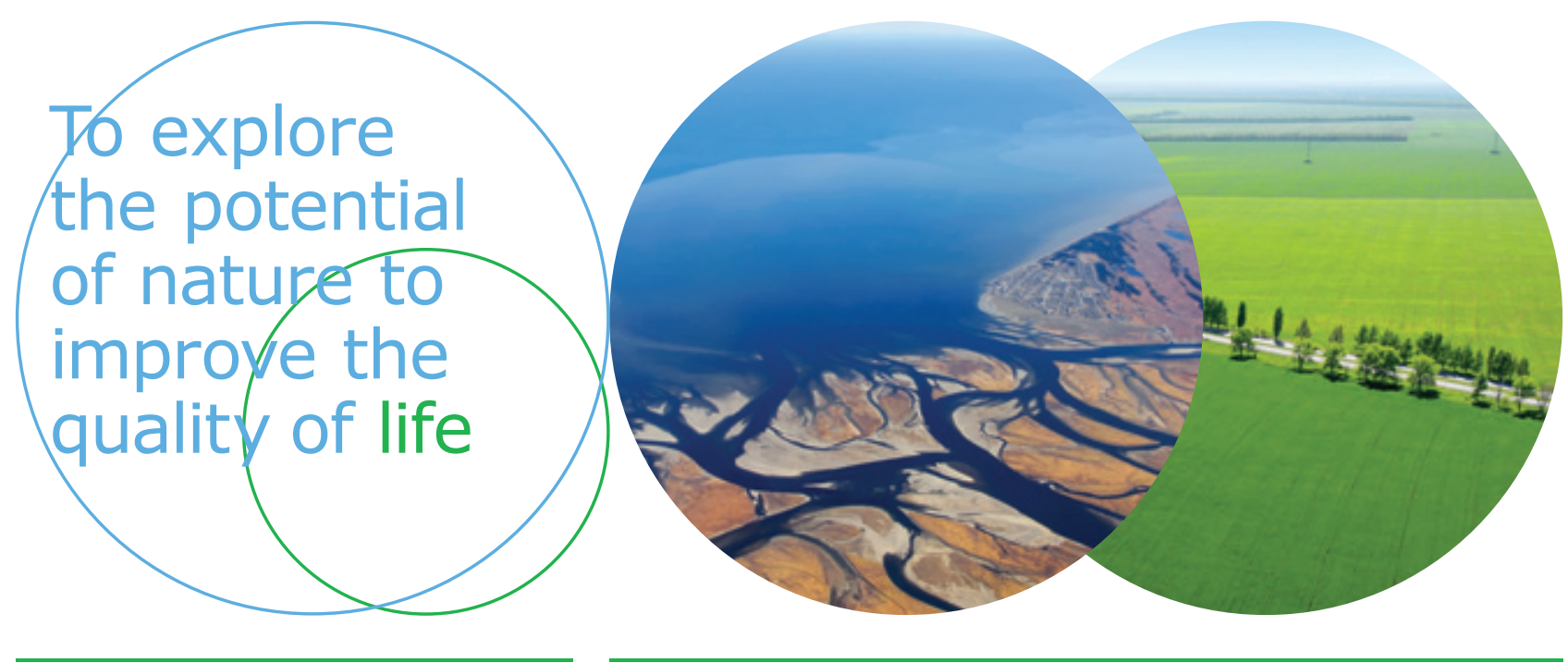

Wageningen Environmental Research Postbus 47

$6700 \mathrm{AB}$ Wageningen

T 317480700

www.wur.nl/environmental-research

Rapport 2912

ISSN 1566-7197
De missie van Wageningen University \& Research is 'To explore the potential of nature to improve the quality of life'. Binnen Wageningen University \& Research bundelen Wageningen University en gespecialiseerde onderzoeksinstituten van Stichting Wageningen Research hun krachten om bij te dragen aan de oplossing van belangrijke vragen in het domein van gezonde voeding en leefomgeving. Met ongeveer 30 vestigingen, 5.000 medewerkers en 10.000 studenten behoort Wageningen University \& Research wereldwijd tot de aansprekende kennisinstellingen binnen haar domein. De integrale benadering van de vraagstukken en de samenwerking tussen verschillende disciplines vormen het hart van de unieke Wageningen aanpak. 